\title{
Geohydrology of the Gallup's Quarry Area, Plainfield, Connecticut
}

U.S. GEOLOGICAL SURVEY

Water-Resources Investigations Report 93-4138

Prepared in cooperation with the U.S. ENVIRONMENTAL PROTECTION AGENCY

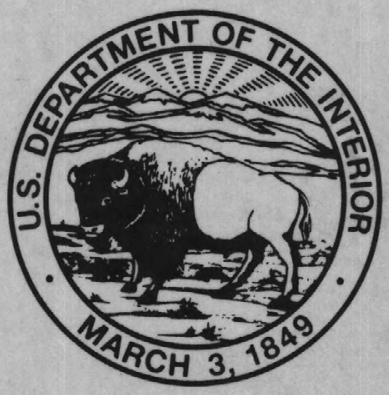





\section{Geohydrology of the Gallup's Quarry Area, Plainfield, Connecticut}

By ROBERT L. MELVIN, JANET RADWAY STONE, PATRICK A. CRAFT, and JOHN W. LANE, JR.

U.S. GEOLOGICAL SURVEY

Water-Resources Investigations Report 93-4138

Prepared in cooperation with the U.S. ENVIRONMENTAL PROTECTION AGENCY

Hartford, Connecticut 1995 


\section{U.S. DEPARTMENT OF THE INTERIOR \\ BRUCE BABBITT, Secretary}

U.S. GEOLOGICAL SURVEY

GORDON P. EATON, Director

For additional information write to:

Copies of this report can be purchased from:

U.S. Geological Survey

District Chief

U.S. Geological Survey

Earth Science Information Center

Open-File Reports Section

450 Main Street

Room 525

Hartford, CT 06103

Box 25286, MS 517

Denver Federal Center

Denver, CO 80225 


\section{FIGURES-Continued}

5. Map showing altitude and configuration of the bedrock surface and location of selected wells in the Gallup's Quarry area.

6. Map showing selected land-use activities in the Gallup's Quarry area ................................................................ 15

7. Map showing $(A)$ surficial geology of part of the Plainfield quadrangle and $(B)$ generalized geologic sections...

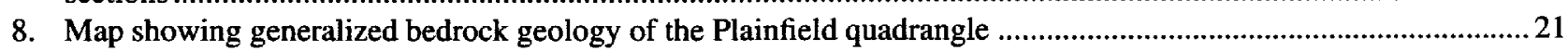

9. Ground-penetrating radar profile along line $\mathrm{R} 1$ and geologic interpretation ...........................................................26

10. Map showing water table at Gallup's Quarry on $(A)$ July 25,1978 , and $(B)$ December 7, 1978 ..........................29

11. Graph showing water levels in U.S. Geological Survey observation well Pl 1, 1978-91 .....................................33

12. Graph showing rating curve for partial-record streamflow-gaging station on Mill Brook at Route 12, Plainfield, Conn.

13. Maps showing lines of equal apparent terrain conductivity in the Gallup's Quarry area, $(A)$ horizontaldipole mode, 20-meter spacing, and $(B)$ vertical-dipole mode, 20-meter spacing..

\section{TABLES}

1. Annual precipitation for $1978-91$ at Norwich, Conn., and North Foster, R.I. . .6

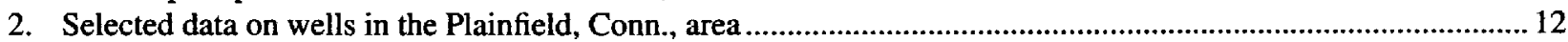

3. Hydraulic properties of stratified drift, till, and crystalline bedrock in Connecticut ........................................28

4. Estimated direction of horizontal ground-water flow and average horizontal gradient in the Gallup's Quarry

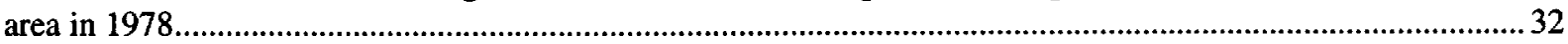

5. Vertical hydraulic gradients estimated from 1978 water levels in wells in the Gallup's Quarry area .....................34

6. Selected flow durations estimated for Mill Brook at Connecticut Route 12 ........................................................ 35

7. Summary of analyses of water samples collected from selected wells at Gallup's Quarry in 1978 ....................... 37 


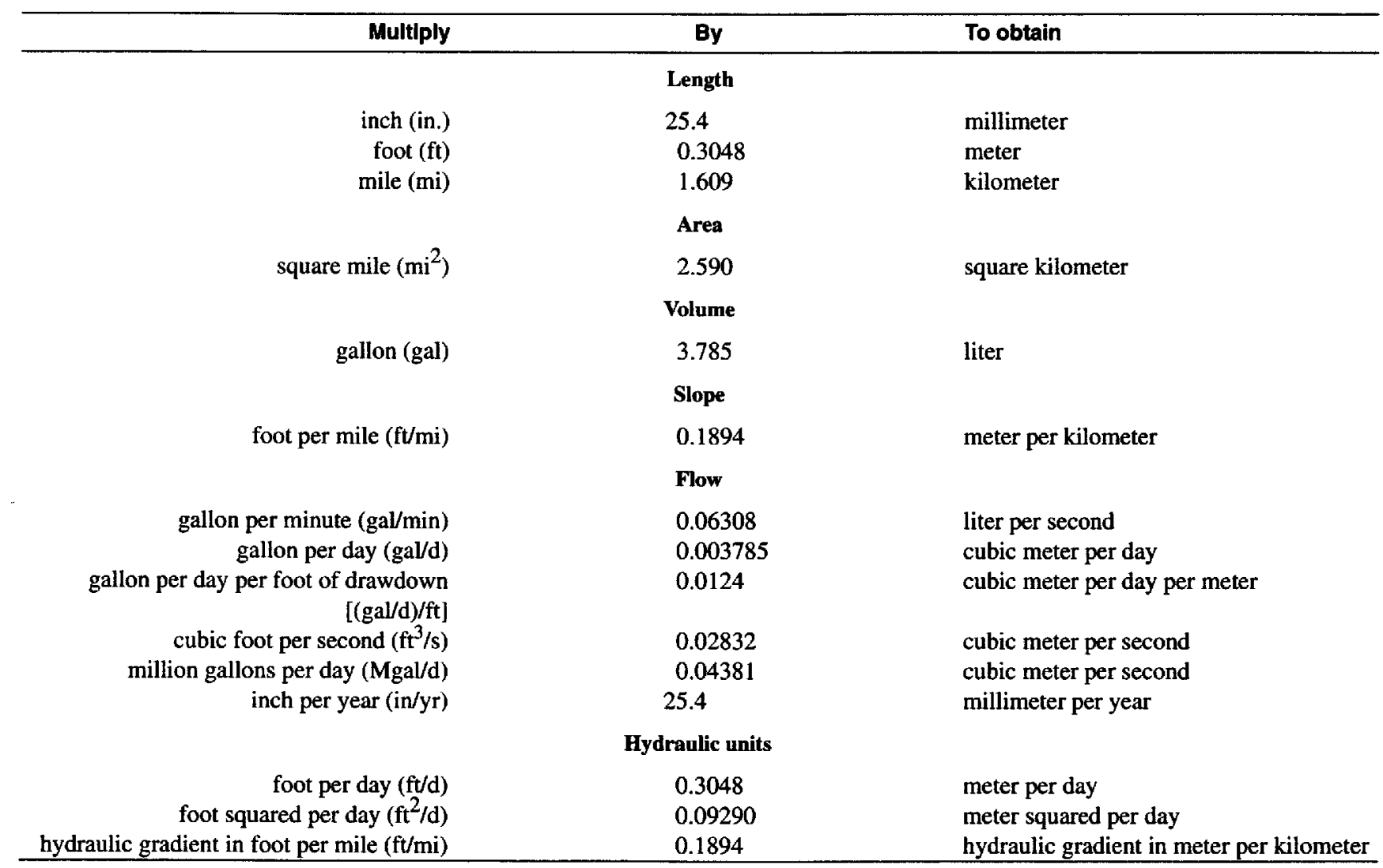

For temperature conversions between degrees Celsius $\left({ }^{\circ} \mathrm{C}\right)$ and degrees Fahrenheit $\left({ }^{\circ} \mathrm{F}\right)$, the following formulas may be used:

$$
\begin{aligned}
& { }^{\circ} \mathrm{C}=5 / 9 \times\left({ }^{\circ} \mathrm{F}-32\right) \\
& { }^{\circ} \mathrm{F}=\left(1.8 \times{ }^{\circ} \mathrm{C}\right)+32 .
\end{aligned}
$$

Abbreviations for water-quality units used in this report:

$\mathrm{mg} / \mathrm{L}$

milligrams per liter

$\mu \mathrm{g} / \mathrm{L}$

micrograms per liter

$\mu \mathrm{S} / \mathrm{cm}$

microsiemens per centimeter at 25 degrees Celsius

Sea level: In this report, "sea level" refers to the National Geodetic Vertical Datum of 1929 (NGVD of 1929)-a geodetic datum derived from a general adjustment of the first-order level nets of both the United States and Canada, formerly called Sea Level Datum of 1929. 


\title{
Geohydrology of the Gallup's Quarry Area, Plainfield, Connecticut
}

\author{
By R.L. Melvin, J.R. Stone, P.A. Craft, and J.W. Lane, Jr.
}

\section{Abstract}

The geohydrology of the Gallup's Quarry area in Plainfield, Conn., was characterized by the U.S. Geological Survey, in cooperation with the U.S. Environmental Protection Agency, to provide a preliminary framework for future remedial efforts. Gallup's Quarry, an inactive sand and gravel pit, was the site of unregulated disposal of an unknown volume of chemical wastes from at least the summer of 1977 until January 1978. Existing information collected for the Connecticut Department of Environmental Protection during 1978-82 showed that ground water beneath Gallup's Quarry and adjacent land to the northwest was contaminated by organic and inorganic compounds. There is also some evidence for contamination of Mill Brook, which is located north and northwest of the disposal areas.

Geologic mapping and subsurface data show that unconsolidated surficial materials up to 90 feet thick overlie fractured crystalline bedrock in most of the Gallup's Quarry area. The surficial materials consist primarily of stratified drift and till. Texture changes vertically and laterally within the stratified drift; grain size ranges from very coarse to fine. Till blankets the bedrock surface beneath the stratified drift and is a few feet to as much as 25 feet thick. Bedrock is exposed at land surface in a hill in the southeastern part of the quarry and slopes to depths of up to 90 feet beneath the area west and north of the disposal sites. The bedrock is a dark, finegrained, fractured and jointed blastomylonite and hornblende gneiss of the Quinebaug Formation. It is likely that a west-northwest-trending fault is present in the bedrock beneath Gallup's Quarry; this fault, if present, may provide a preferential pathway for ground-water flow and contaminant transport.

The principal horizontal direction of ground-water flow and movement of dissolved contaminants in the stratified drift was to the northwest of the waste-disposal areas toward Mill Brook in 1978. Estimates of average annual recharge based on regional analyses for 1978-91 are 30 inches in areas where stratified drift are exposed and 9.6 inches in areas where till and crystalline bedrock are exposed. The hydraulic conductivity of the coarse-grained stratified drift, identified in earlier U.S. Geological Survey studies as part of an aquifer capable of yielding large quantities of water, may be several hundred feet per day. The hydraulic conductivity of the till, based on regional information, is likely 0.04 to 24 feet per day.

More detailed geohydrologic information is required to develop effective remedial programs at Gallup's Quarry, particularly in the areas north and west of the waste-disposal areas. Detailed subsurface geologic mapping and definition of head distribution and other hydraulic properties of each geohydrologic unit would indicate directions and rates of ground-water flow. Most importantly, the present extent of contamination of water and sediments throughout the area will have to be determined.

\section{INTRODUCTION}

In 1992, the U.S. Geological Survey (USGS), in cooperation with the U.S. Environmental Protection 
Agency (USEPA), began geohydrologic investigations of selected Superfund sites in New England. The objective was to develop a preliminary characterization and understanding of the regional and local geohydrology of the sites using existing data, supplemented by a limited amount of new data primarily collected by noninvasive methods, such as surface geophysical surveys. The geohydrologic characterization is expected to be used to guide development of the scope of Superfund Remedial Investigation/Feasibility Studies that will be required at these sites.

Gallup's Quarry, the first New England area selected for study under the USGS/USEPA program, is an inactive sand and gravel pit about $1 \mathrm{mi}$ south of the village of Plainfield, Conn. The quarry is located on the south-central part of the USGS Plainfield 7.5-minute topographic quadrangle map and is bounded to the south by Tarbox Road, to the north by a swampy lowland that extends to Mill Brook, to the west by the Conrail Railroad right of way, and to the east by residential properties that border the western side of Connecticut Route 12 (fig. 1). It was used for disposal of chemical wastes (Fuss and O'Neill, 1979) from the summer of 1977, or possibly earlier (U.S. Environmental Protection Agency, 1990), until January 1978.

\section{Purpose and Scope}

This report describes the geohydrology of the Gallup's Quarry area. It contains a summary of several published reports and maps that were reviewed as part of this study, as well as information obtained from files of the USEPA, USGS, the Connecticut Department of Environmental Protection (DEP), and the town of Plainfield. The report also contains the results of field work, which included detailed geologic mapping of the study area, with emphasis on interpreting the subsurface distribution of unconsolidated glacial deposits and bedrock structural features; surfacegeophysical surveys; test-hole drilling to confirm geologic interpretation of surface-geophysical records; installation of an observation well to measure watertable fluctuations; and measurements of the flow and specific conductance of Mill Brook. The surfacegeophysical surveys included 9 electromagnetic (EM) profile lines with an aggregate length of about $6,000 \mathrm{ft}$ and 11 ground-penetrating radar (GPR) profile lines with a total length of about $5,000 \mathrm{ft}$. Locations of USGS data-collection sites, together with selected data-collection sites used in previous studies, are shown on plate 1 (in pocket). The report also includes a section on additional data that would be needed to complete a remedial investigation and feasibility study.

\section{Previous Studies}

The Gallup's Quarry area is included in a regional hydrologic study of the Quinebaug River Basin (Randall and others, 1966). The surficial and bedrock geology of the study area are described in maps and reports by Stone and Randall (1977), Stone (1974), and Dixon (1965, 1968).

The history of known waste-disposal, remediation, and monitoring activities at Gallup's Quarry has recently been summarized by Metcalf and Eddy (1992). The only previous geohydrologic study of Gallup's Quarry was conducted by Fuss and O'Neill (1979) on behalf of the DEP. Fuss and O'Neill determined that chemical wastes had been disposed of at three locations (pl. 1)-a buried seepage system into which an unknown quantity of low-pH liquids containing several heavy metals and dyes had been discharged and two separate pits where barrels had been buried and liquid chemical waste had been discharged. The extent of contaminated glacial sediments and ground water was estimated from analyses of samples collected from test pits and monitoring wells. Barrels and contaminated sediments were removed in 1978, under the supervision of Fuss and O'Neill and the DEP staff, and transported off the site.

The DEP Water Compliance Unit conducted a monitoring program from November 1978 to November 1985. Water samples from Mill Brook and from several observation wells installed by Fuss and O'Neill and the DEP were periodically collected and analyzed for selected physical properties and chemical constituents. Sediment samples from Mill Brook were also analyzed for selected chemical constituents, and biological monitoring of this stream was conducted at least once (Joseph Nestico, Department of Environmental Protection, written commun., 1986). Other monitoring activities were conducted for the USEPA by NUS Corporation in 1986 (Kenneth Jones, NUS Corp., written commun., 1987) and by Roy F. Weston, Inc., in 1989 (Alex Sherrin, U.S. Environmental Protection Agency, written commun., 1989). 


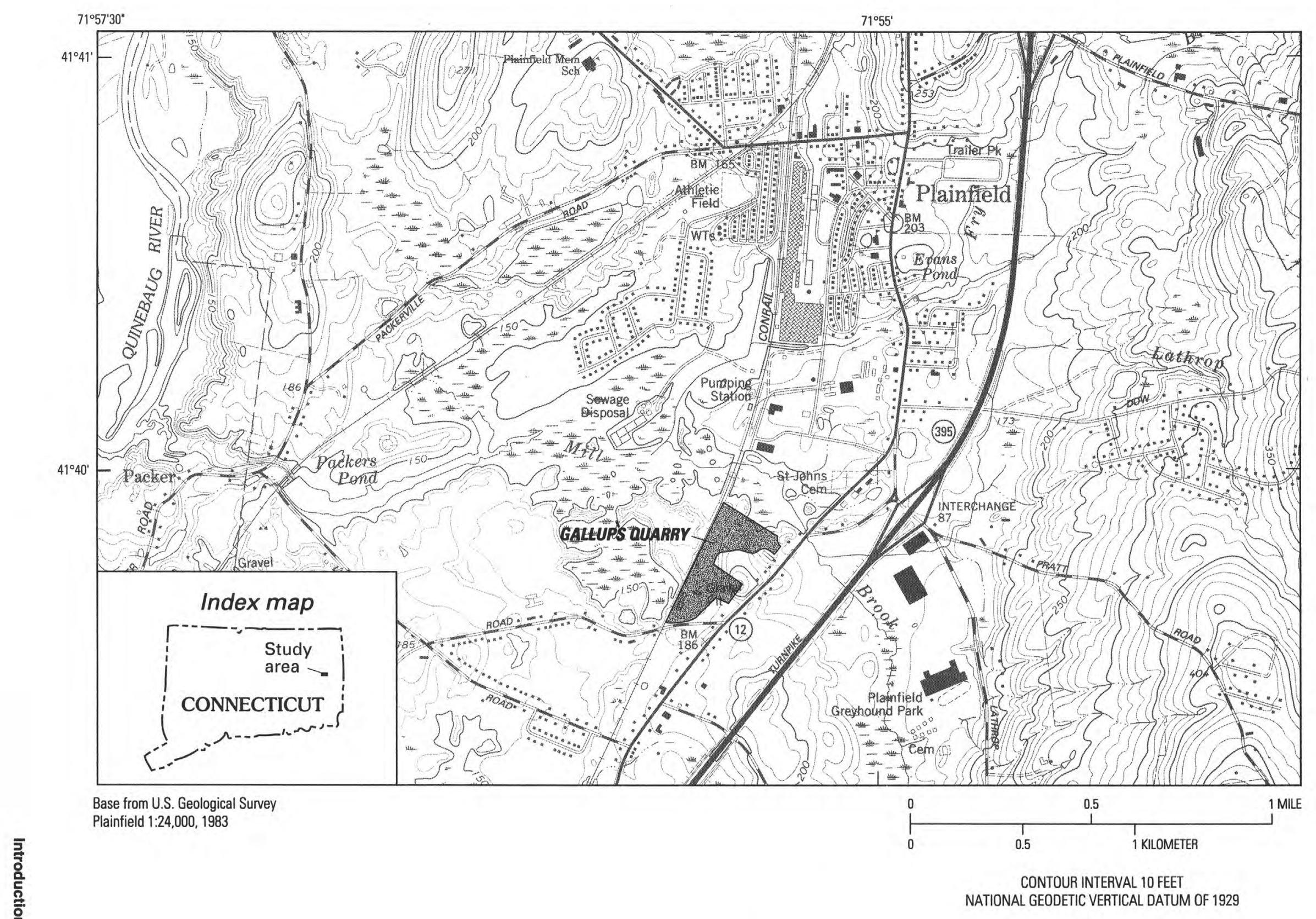

$\omega$ Figure 1. Location of Gallup's Quarry in Plainfield, Conn. 


\section{REGIONAL PHYSICAL AND HYDROLOGIC SETTING}

\section{Physiography}

Gallup's Quarry lies along the eastern border of the Quinebaug Valley lowland, a north-south-trending area in eastern Connecticut that is 2 to $3 \mathrm{mi}$ wide and about $25 \mathrm{mi}$ long. This area of relatively low relief is underlain by thick glacial meltwater deposits (stratified drift) and is drained by sluggish streams and extensive swamps. Land-surface altitudes in the lowland near Gallup's Quarry are generally 150 to $200 \mathrm{ft}$ above sea level, and altitudes of areas in the Quinebaug River flood plain are as low as $100 \mathrm{ft}$ above sea level. The lowland is bounded to the east and west by uplands, which are irregular, hilly areas of moderate relief, large bedrock ledges, generally thin glacial deposits (predominantly till), small swamps, and poorly drained valleys. Land surfaces in the uplands to the east of Gallup's Quarry are from 200 to $600 \mathrm{ft}$ above sea level.

The physiography of this region is defined at the large scale by the lithology and structure of the metamorphic bedrock of Proterozoic age, which controls the positions of the major hills and valleys. At a smaller scale, the landscape is defined by the distribution of glacial sediments of late Pleistocene age, which partly fill the bedrock valleys and discontinuously blanket the bedrock hills. Other details of the landscape are related to postglacial melting of buried ice blocks that produced the large kettle-hole swamps common in the Quinebaug Valley lowland and postglacial terracing that produced the modern flood plains. Finally, human activities - the extraction of sand and gravel, in particular-have significantly altered the original land surface.

Gallup's Quarry is in the lower part of the Mill Brook drainage basin (fig. 2). Mill Brook, a tributary of the Quinebaug River, drains westerly from the eastern uplands into the Quinebaug Valley lowland. It drains about $18 \mathrm{mi}^{2}$ (Thomas, 1972), half of which is upstream from Gallup's Quarry. (See fig. 2.) Most of the drainage area is east of the Quinebaug Valley lowland in the upland parts of the USGS Plainfield, Jewett City, and Oneco 7.5-minute topographic quadrangle maps. The lower part of the Mill Brook Basin, which includes the study area, is in the Quinebaug Valley lowland. Major tributaries to Mill Brook, in downstream order, are Reservoir Brook, Lathrop Brook, and Fry Brook. The latter stream, which receives wastewater discharges, joins Mill Brook just downstream from Gallup's Quarry, and the municipal sewage-disposal plant is located near their confluence. Mill Brook is dammed near the junction of Lillibridge Road and Packer Road. The impoundment, known as Packers Pond, extends about $3,700 \mathrm{ft}$ upstream, and its upstream terminus is about $3,000 \mathrm{ft}$ northwest of Gallup's Quarry. Extensive wetlands border sections of Mill Brook north and west of the study area and upstream of Interstate Route 395 (formerly the Connecticut Turnpike). Smaller wetlands are found throughout the drainage basin. The Mill Brook drainage basin provides a useful physical framework for describing the regional hydrology, particularly the circulation of water.

\section{Hydrology}

The regional hydrologic setting for the Gallup's Quarry area has been described by Randall and others (1966). Some information in this reference, such as the precipitation, streamflow, and water-quality data, is of limited use as it is almost 30 years old. The Mill Brook drainage basin (fig. 2) will be used as the physical framework for discussing most of the regional hydrology. The area within the boundaries of this basin, under natural conditions, can be considered a virtually closed system-water entering the basin is limited to the precipitation that falls on the land, and water leaving the basin is almost entirely through streamflow or evapotranspiration to the atmosphere. Throughout most of Mill Brook Basin, the surfacewater drainage divide approximates the horizontal boundaries of the surface-water and ground-water flow systems. However, in the central and downstream parts of the basin, the surface-water drainage divide crosses several low areas of stratified drift where the ground-water divide can not be accurately defined by existing data. If the surface-water and ground-water divides do not coincide, the extent of the surface-water and ground-water flow systems will differ. The position of the ground-water divides also may shift in response to large withdrawals from wells or a significant natural stress such as a prolonged drought. In addition, manmade diversions bring water into and out of this basin and are described in this report in the section "Water Supply and Wastewater Disposal."

Gallup's Quarry is in the State's Central climate division, which is characterized by normal temperatures of about $50{ }^{\circ} \mathrm{F}$ and normal precipitation of 45 to 50 in. The coldest month is January (normal temperature of $25.8^{\circ} \mathrm{F}$ ) and the warmest is July (normal temperature of $71.4^{\circ} \mathrm{F}$ ); monthly precipitation, in general, is evenly distributed. Published National 


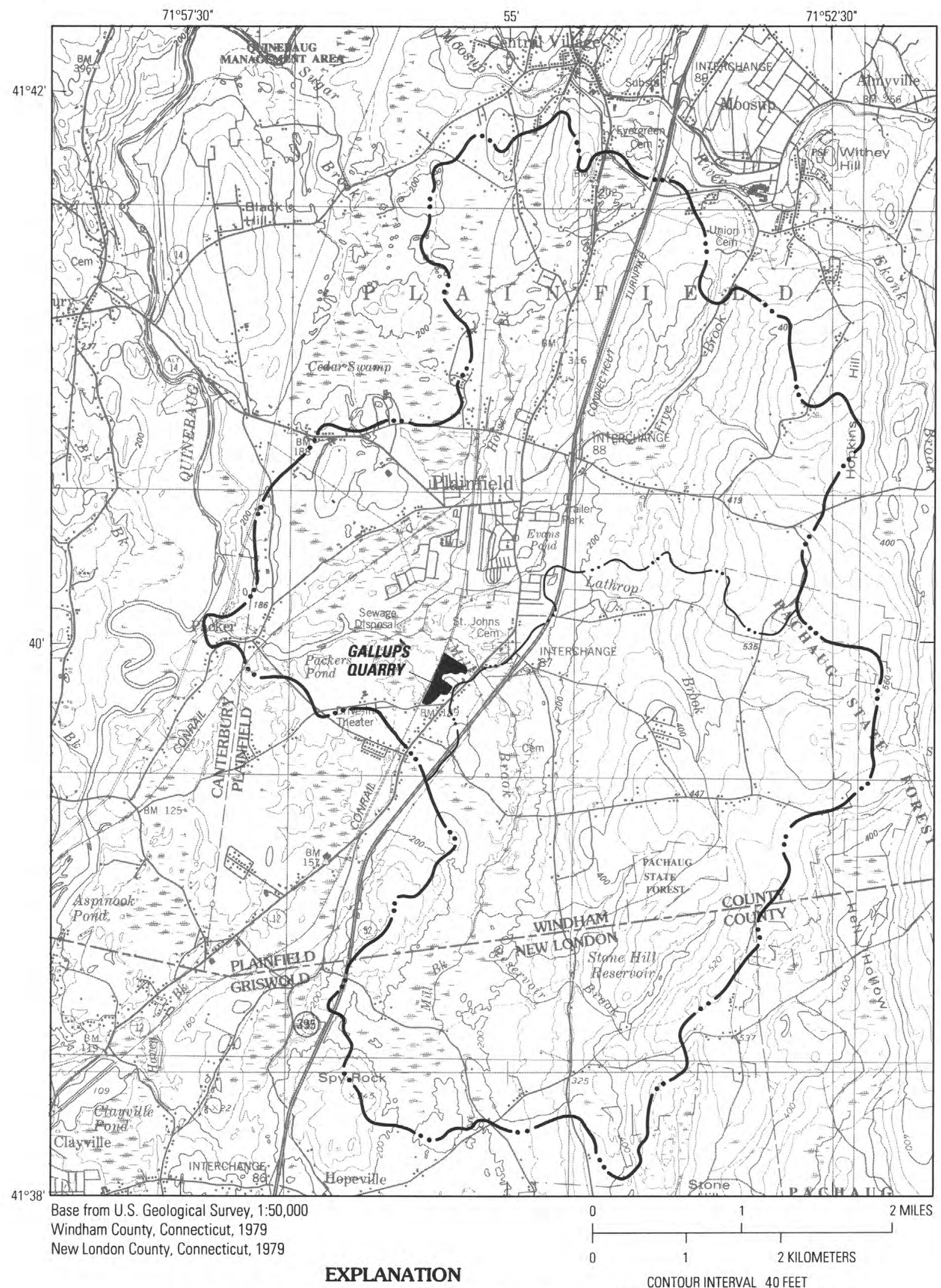

EXPLANATION

-.. Basin divide-Shows boundary of Mill Brook Basin

NATIONAL GEODETIC VERTICAL DATUM OF 1929

Subbasin divide-Shows boundary of Mill Brook and Lathrop Brook drainage above Connecticut Route 12 (U.S. Geological Survey streamflow-gaging station 011266.42) 
Weather Service annual precipitation data (National Oceanic and Atmospheric Administration, 1979-92) for nearby stations in Norwich, Conn. (about $12 \mathrm{mi}$ to the southwest), and North Foster, R.I. (about $16 \mathrm{mi}$ to the northeast), from January 1978 to December 1991 are summarized in table 1. During this period, which starts at about the time waste-disposal activities were first discovered by State agencies, the median and average annual precipitation were 53.6 and 53.3 in. at Norwich and 51.5 and 52.7 in. at North Foster.

Table 1. Annual precipitation for 1978-91 at Norwich, Conn., and North Foster, R.I.

[Precipitation data from National Oceanic and Atmospheric Administration (1979-92). All values are in inches]

\begin{tabular}{|c|c|c|}
\hline Station location & Year & Precipitation \\
\hline \multirow[t]{14}{*}{ Norwich, Connecticut } & 1978 & 53.13 \\
\hline & 1979 & 63.71 \\
\hline & 1980 & 41.28 \\
\hline & 1981 & 45.84 \\
\hline & 1982 & 54.05 \\
\hline & 1983 & 68.36 \\
\hline & 1984 & 51.66 \\
\hline & 1985 & 54.80 \\
\hline & 1986 & 54.30 \\
\hline & 1987 & 41.59 \\
\hline & 1988 & 45.37 \\
\hline & 1989 & 64.63 \\
\hline & 1990 & 58.88 \\
\hline & 1991 & 49.03 \\
\hline \multirow[t]{14}{*}{ North Foster, Rhode Island } & 1978 & 51.04 \\
\hline & 1979 & 59.82 \\
\hline & 1980 & 45.47 \\
\hline & 1981 & 47.77 \\
\hline & 1982 & 56.08 \\
\hline & 1983 & 66.63 \\
\hline & 1984 & 54.00 \\
\hline & 1985 & 43.32 \\
\hline & 1986 & 49.67 \\
\hline & 1987 & 46.66 \\
\hline & 1988 & 46.43 \\
\hline & 1989 & 55.10 \\
\hline & 1990 & 63.95 \\
\hline & 1991 & 51.95 \\
\hline
\end{tabular}

Median, maximum, and minimum monthly precipitation differed considerably as shown in figure 3 . The average annual precipitation at Gallup's Quarry for the same period is assumed equal to the average of these two nearby stations, which is 53 in.

Previous hydrologic studies in eastern Connecticut (Randall and others, 1966; Thomas and others, 1967) indicate that about 40 percent of this average annual precipitation, or $21 \mathrm{in} / \mathrm{yr}$, is returned directly to the atmosphere through evapotranspiration. For the 1978-91 reference period there is, therefore, an average annual remainder of approximately $32 \mathrm{in.} \mathrm{of}$ water that (1) runs off the land surface to nearby streams, swamps, and lakes (direct runoff); (2) percolates to the saturated zone and flows to natural groundwater discharge points such as streams, swamps, lakes, and springs; or (3) is withdrawn by supply wells. The ground-water discharge to streams and lakes is termed ground-water runoff and together with direct runoff comprises the total runoff from a drainage basin. All runoff within the Mill Brook drainage basin is assumed to be to Mill Brook and its tributaries. Because evapotranspiration losses remain fairly constant from year to year, the total runoff in any year is roughly equivalent to the precipitation minus the evapotranspiration (Randall and others, 1966, fig. 5). Total runoff for 1978-91 averaged $32 \mathrm{in} / \mathrm{yr}$ and was considerably larger than the average of about $24 \mathrm{in} / \mathrm{yr}$ measured in the Quinebaug River Basin for 1919-62 (Randall and others, 1966). Average precipitation during 1919-62, however, was only about $44.8 \mathrm{in} / \mathrm{yr}$, which was about 8 in. less than that during 1978-91.

The relative amounts of direct runoff and ground-water runoff can be estimated by a regionalization technique, developed in previous studies in Connecticut, that is based on the percentage of drainage area underlain by stratified drift (Mazzaferro and others, 1979, p. 45). About 16 percent of Mill Brook Basin, upstream of Connecticut Route 12, is underlain by stratified drift. The long-term average annual runoff for Mill Brook at this location is estimated to consist of about 55 percent direct runoff and 45 percent ground-water runoff on the basis of the regional method of analyses. This runoff is equivalent to an average of about $17.6 \mathrm{in} / \mathrm{yr}$ of direct runoff and $14.4 \mathrm{in} / \mathrm{yr}$ of ground-water runoff for the period 1978-91. The relative amounts of direct runoff and ground-water runoff in any year could differ considerably from these averages if the ratio of ground-water runoff to total runoff changed significantly from year to year. Estimates of runoff components could be similarly made at any other location on Mill Brook, 


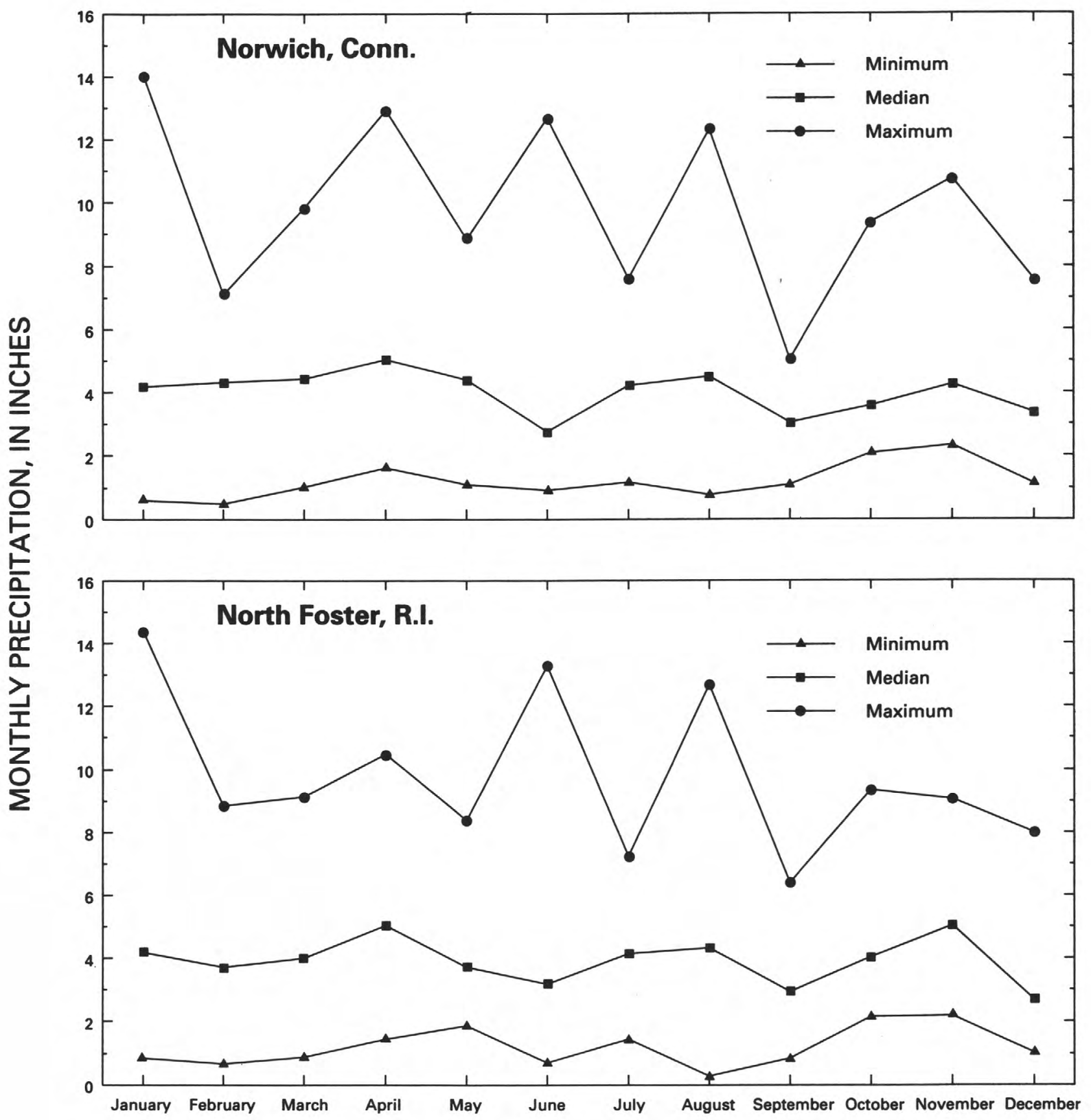

Figure 3. Median, maximum, and minimum monthly precipitation for 1978-91 at Norwich, Conn., and North Foster, R.I. 
but it should be noted that the discharge from the municipal wastewater-disposal facility affects runoff below the confluence of Fry Brook and Mill Brook.

\section{Water Supply and Wastewater Disposal}

Potable water is provided to people in the southcentral part of Plainfield in one of two ways - by public supply systems or by individual onsite wells. The term "public supply" does not refer to the ownership of the company, but to the customers of the company. Information on public water supply in the Plainfield area was provided by Richard L. Mercier of the Gallup Water Service Company and Stephen Messer of the Connecticut Department of Health Services. Local public suppliers include the Gallup Water Service Company, the Brookside Water Company, and the Glen Acres Water Company. The Gallup Water Service Company currently (1993) owns the Brookside Water Company and is in the process of trying to acquire the Glen Acres Company; however, because each of these companies still have distinct distribution systems and water-supply sources, their supply systems are discussed separately.

The present Gallup Water Service Company's supply system incorporates an original system that was installed by Lawton Mills ${ }^{1}$ at the turn of the century. Current sources of water for this system are two 18-in.-diameter gravel-pack wells located next to two 125,000 -gal steel storage tanks on the western side of the village. (See fig. 4A.) One of these wells (Pl 185) is shown in figure 5. Withdrawals from these two wells average approximately $1,000 \mathrm{gal} / \mathrm{min}$ during 5 to 6 hours per day and total 300,000 to $400,000 \mathrm{gal} / \mathrm{d}$. The water is stored in the steel storage tanks and then distributed to approximately 575 domestic, commercial, and industrial service connections in the southern half of Plainfield. The estimated population served is between 1,500 and 1,800 persons. An additional 420,000-gal concrete storage tank is located at an industrial park on the eastern side of Interstate Route 395, north of Lathrop Road. The approximate areal extent of the water service area is shown in figure $4 A$. The southern limit of the distribution system

\footnotetext{
${ }^{1}$ The use of trade, product, industry, or firm names in this report is for identification or location purposes only, and does not constitute endorsement of products by the U.S. Geological Survey, nor impute responsibility for any present or potential effects on the natural resources.
}

is in the industrial area that is north of St. John's Cemetery and west of Connecticut Route 12. No properties adjacent to Gallup's Quarry are served by the Gallup Water Service Company.

The Brookside Water Company, created in the early 1970 's to serve a new subdivision, was purchased by the Gallup Water Service Company in 1984. The system is presently supplied by two wells located near an unnamed pond as indicated in figure $4 A$. After withdrawal, water is stored in a 100,000 -gal concrete tank and is subsequently distributed to the approximately 200 domestic service connections. The areal extent of the Brookside Water Company distribution system is shown in figure $4 A$ - the area closest to Gallup's Quarry that is served by the Brookside Water Company is a shopping center on the southeastern side of the intersection of Interstate Route 395 and Lathrop Road.

The Glen Acres Water Company was created in the early 1970's and was designed to serve the Glen Acres subdivision (fig. 4A). The water for this supply system is withdrawn from two wells located south of Tarbox Road, approximately $2,200 \mathrm{ft}$ east of the intersection of Tarbox and Lillibridge Roads. This water system does not have a master meter, and therefore, actual withdrawals are unknown. After withdrawal, water is stored in a 2,500- to 3,000-gal pressurized tank before release into the distribution system, the extent of which is shown in figure $4 A$. This company has approximately 30 to 40 domestic service connections. In the last 10 years, some customers have chosen to install private wells because of high iron and manganese concentrations in the publicly supplied water (R.L. Mercier, Gallup Water Service Company, and Steven Messer, Connecticut Department of Health Services, Water Supplies Section, oral commun., 1993).

Those properties that do not fall within the public water-supply distribution areas shown in figure $4 A$ are assumed to be self-supplied by individual wells. This includes all properties that are directly adjacent to Gallup's Quarry. The records of several wells located near Gallup's Quarry were obtained from Thomas and others (1966) and USGS and DEP files. The locations of these wells are shown in figure 5, and information on discharge, depth, and aquifer is presented in table 2. Data for other wells shown in figure 5 that are farther away from Gallup's Quarry are contained in Thomas and others (1966). The Plainfield Greyhound Racetrack is self-supplied by a bedrock well, but no data on the well were available. 


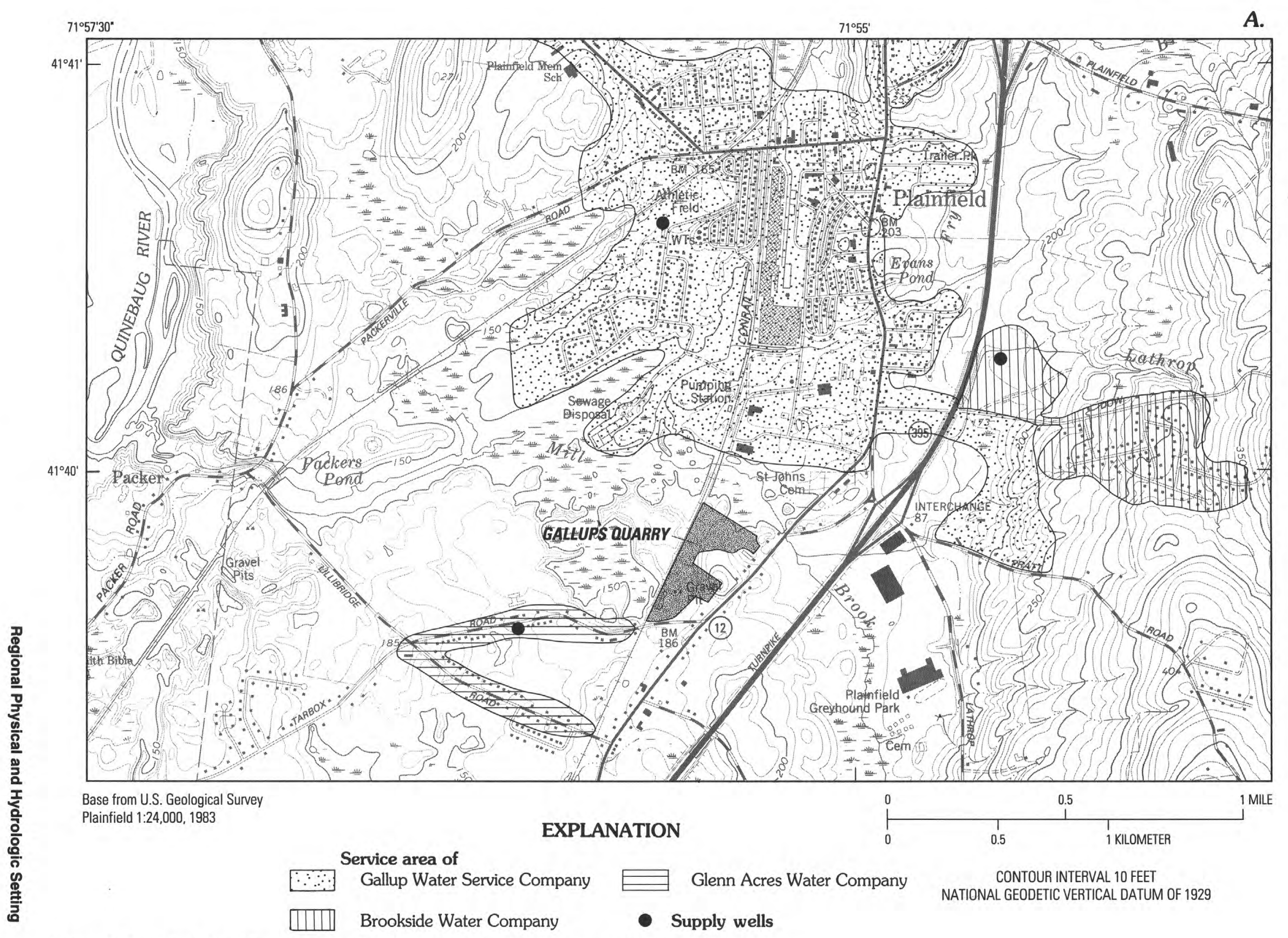

- Figure 4A. Extent of public water-supply system in the Gallup's Quarry area in 1992. 


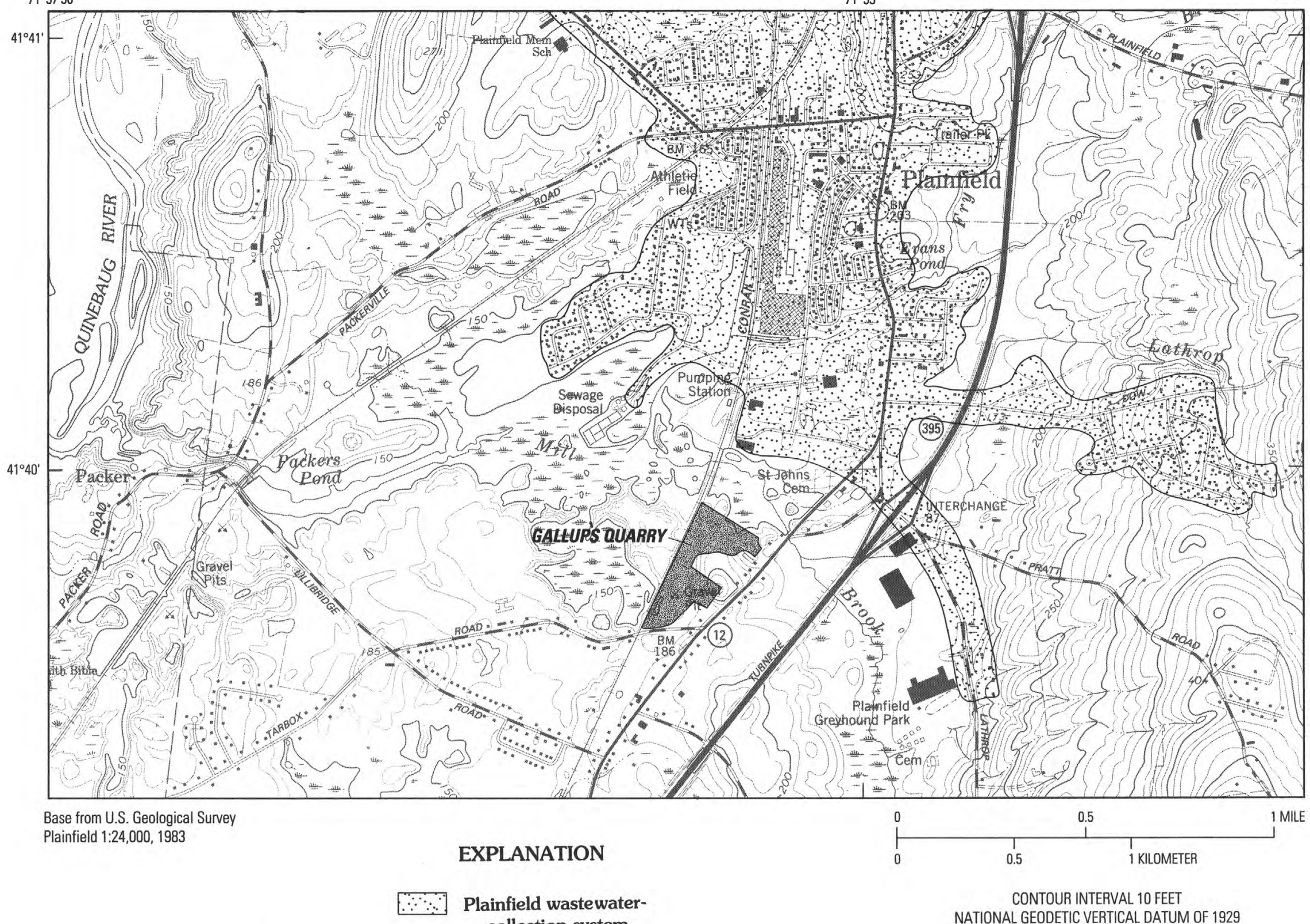

Figure 4B. Extent of wastewater-collection system in the Gallup's Quarry area in 1992. 


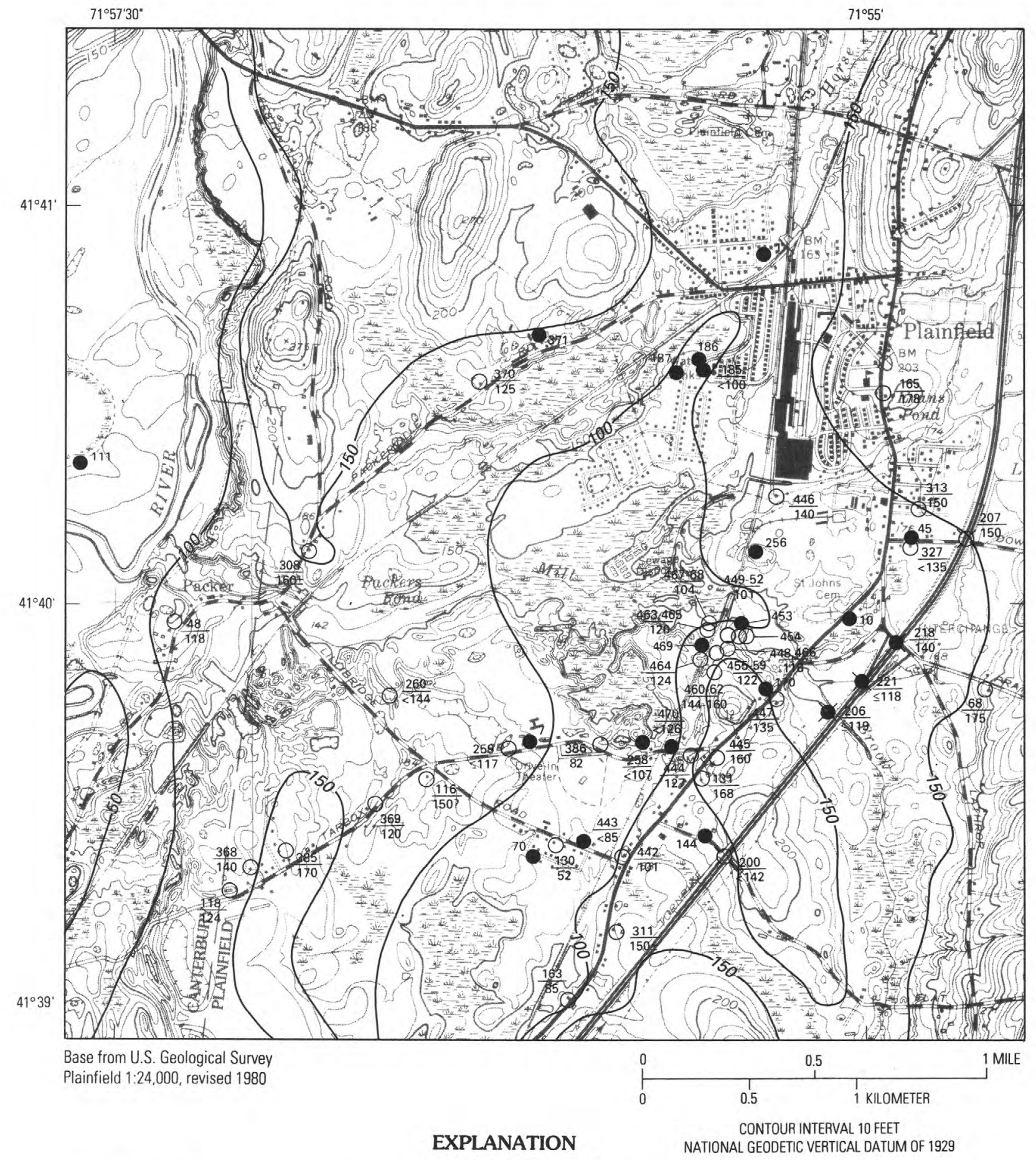

- 100 - Bedrock contour-Shows altitude of bedrock surface. Contour interval 50 feet. Datum is National Geodetic Vertical Datum of 1929

$\mathrm{O}^{\frac{446}{140}} \quad$ Well-Upper number is local town well number used in U.S. Geological Survey publications. Lower number (if any) is altitude of the bedrock surface. Solid symbol indicates well did not penetrate bedrock; <, less than; $\leq$, less than or equal to

Figure 5. Altitude and configuration of the bedrock surface and location of selected wells in the Gallup's Quarry area. 
Table 2. Selected data on wells in the Plainfield, Conn., area

[Local USGS well number, U.S. Geological Survey sequential number assigned to each well in a town. Depth of well, depth to bottom of well in feet below landsurface datum. Bottom of casing, depth to bottom of well casing in feet below land-surface datum. Type of finish: G, screen with gravel pack; O, open end; S, well screen; X, open hole; W, walled with fieldstone; Water level, nonpumping water level in feet below land-surface datum; Aquifer: SD, stratified drift; T, till; $\mathrm{CB}$, noncarbonate crystalline bedrock; >, more than; --, no data; F\&O, Fuss and O’Neill consulting engineers]

\begin{tabular}{|c|c|c|c|c|c|c|c|c|c|c|c|c|c|}
\hline $\begin{array}{l}\text { Local } \\
\text { USGS } \\
\text { well } \\
\text { number }\end{array}$ & $\begin{array}{c}\text { Site } \\
\text { identification } \\
\text { number }\end{array}$ & $\begin{array}{c}\text { Date of } \\
\text { con- } \\
\text { struction }\end{array}$ & $\begin{array}{c}\text { Altitude } \\
\text { of land } \\
\text { surface } \\
\text { (feet) }\end{array}$ & $\begin{array}{c}\text { Depth of } \\
\text { well } \\
\text { (feet) }\end{array}$ & $\begin{array}{l}\text { Diameter } \\
\text { of casing } \\
\text { (inches) }\end{array}$ & $\begin{array}{c}\text { Bottom } \\
\text { of casing } \\
\text { (feet) }\end{array}$ & $\begin{array}{l}\text { Type of } \\
\text { finish }\end{array}$ & $\begin{array}{l}\text { Water } \\
\text { level } \\
\text { (feet) }\end{array}$ & $\begin{array}{c}\text { Date water } \\
\text { level } \\
\text { measured }\end{array}$ & $\begin{array}{c}\text { Dis- } \\
\text { charge } \\
\text { (gal/min) }\end{array}$ & $\begin{array}{c}\text { Depth } \\
\text { to } \\
\text { bedrock } \\
\text { (feet) }\end{array}$ & Aquifer & Remarks \\
\hline PL 1 & 414054071552001 & 1900 & 180.00 & 34.0 & 36 & - & w & 31.0 & $10-01-42$ & - & $>34$ & SD & $\begin{array}{c}\text { U.S. Geological Survey } \\
\text { observation well }\end{array}$ \\
\hline PL 131 & 413934071553301 & $06-10-60$ & 180 & 76 & 6 & 15 & $\mathrm{x}$ & 19 & $06-10-60$ & $15+$ & 12 & $\mathrm{CB}$ & \\
\hline PL. 185 & 414036071553301 & 1961 & 164 & 64 & 18 & 50 & G & 11.1 & $03-05-62$ & 1,500 & $>64$ & SD & Public-supply well \\
\hline PL 386 & 413939071555301 & $04-07-64$ & 168 & 134 & 6 & 90 & $\mathrm{x}$ & 20 & $04-07-64$ & 7 & 86 & $\mathrm{CB}$ & \\
\hline PL 442 & 413922071554801 & $11-16-87$ & 165 & 365 & 6 & 74 & $\mathrm{x}$ & 20 & $11-16-87$ & 2.5 & 64 & SD & \\
\hline PL 443 & 413925071555601 & $07-17-78$ & 165 & 80 & 6 & 80 & $\mathrm{O}$ & 30 & $07-17-78$ & 10 & $>80$ & SD & \\
\hline PL 444 & 413937071553501 & $10-30-81$ & 170 & 145 & 6 & 43 & $\mathrm{X}$ & 25 & $10-30-71$ & 6 & 43 & $\mathrm{CB}$ & \\
\hline PL 445 & 413937071553001 & $10-02-72$ & 175 & 200 & 6 & 20 & $\mathrm{x}$ & 20 & $10-02-72$ & 3.5 & 15 & $\mathrm{CB}$ & \\
\hline PL 446 & 414016071551801 & 08-07-72 & 165 & 400 & 6 & 30 & $\mathrm{X}$ & 20 & $08-07-72$ & .5 & 25 & $\mathrm{CB}$ & \\
\hline PL 447 & 413946071551701 & $11-26-80$ & 170 & 150 & 6 & 45 & $\mathrm{X}$ & 30 & $11-26-80$ & 4 & 35 & $\mathrm{CB}$ & \\
\hline PL 448 & 413955071552601 & $06-26-78$ & 161.6 & 35 & 1.25 & 25 & S & 17.8 & $07-25-78$ & - & 43.5 & SD & $\begin{array}{l}\text { Monitoring well SWI } \\
\text { installed by F\&O (1979) }\end{array}$ \\
\hline PL 449 & 413956071552601 & $06-27-78$ & 161.10 & 28.5 & 1.25 & 18.5 & S & 17.1 & $07-25-78$ & - & $>28.5$ & SD & $\begin{array}{c}\text { Monitoring well SW2S } \\
\text { installed by F\&O (1979) }\end{array}$ \\
\hline PL. 450 & 413956071552602 & $06-27-78$ & 161.10 & 54.0 & 1.25 & 44.0 & S & 17.4 & $07-25-78$ & - & 60 & SD & $\begin{array}{c}\text { Monitoring well SW2D } \\
\text { installed by F\&O (1979) }\end{array}$ \\
\hline PL 451 & 413956071552801 & $06-29-78$ & 157.1 & 29.0 & 1.25 & 19.0 & S & 12.9 & $07-25.78$ & - & $>36$ & SD & $\begin{array}{c}\text { Monitoring well SW3S } \\
\text { installed by F\&O }\end{array}$ \\
\hline PL 452 & 413956071552802 & $06-29-78$ & 157.1 & 51.0 & 1.25 & 41.0 & S & 14.6 & $07-25-78$ & - & $>56$ & SD & $\begin{array}{l}\text { Monitoring well SW3D } \\
\text { installed by F\&O (1979) }\end{array}$ \\
\hline \multirow[t]{2}{*}{ PL 453} & 413955071552401 & $07-20-78$ & 149.2 & 30.0 & 1.25 & 20.0 & $S$ & 5.33 & $07-25-78$ & -- & $>30$ & SD & $\begin{array}{l}\text { Monitoring well SW4 } \\
\text { installed by F\&O (1979) }\end{array}$ \\
\hline & & & & & & & & & & & & $\mathrm{T}$ & $\begin{array}{l}\text { Screened in stratified drift } \\
\text { and till }\end{array}$ \\
\hline PL 454 & 413954071552501 & $07-20-78$ & 151.4 & 22.0 & 1.25 & 12.0 & $\mathrm{~S}$ & 6.66 & $07-25-78$ & - & 22 & $\mathrm{SD}$ & $\begin{array}{l}\text { Monitoring well SW5 } \\
\text { installed by F\&O (1979) }\end{array}$ \\
\hline PL 455 & 413954071552801 & $06-30-78$ & 159.1 & 30.0 & 1.25 & 20.0 & $\mathbf{S}$ & 14.9 & $07-25-78$ & -- & 36.5 & $\mathrm{~T}$ & $\begin{array}{l}\text { Monitoring well SW6 } \\
\text { installed by F\&O (1979) }\end{array}$ \\
\hline
\end{tabular}


Table 2. Selected data on wells in the Plainfield, Conn., area-Continued

\begin{tabular}{|c|c|c|c|c|c|c|c|c|c|c|c|c|c|}
\hline $\begin{array}{l}\text { Local } \\
\text { USGS } \\
\text { well } \\
\text { number }\end{array}$ & $\begin{array}{c}\text { Site } \\
\text { identification } \\
\text { number }\end{array}$ & $\begin{array}{c}\text { Date of } \\
\text { con- } \\
\text { struction }\end{array}$ & $\begin{array}{c}\text { Altitude } \\
\text { of land } \\
\text { surface } \\
\text { (feet) }\end{array}$ & $\begin{array}{c}\text { Depth of } \\
\text { well } \\
\text { (feet) }\end{array}$ & $\begin{array}{c}\text { Diameter } \\
\text { of casing } \\
\text { (inches) }\end{array}$ & $\begin{array}{l}\text { Bottom } \\
\text { of casing } \\
\text { (feet) }\end{array}$ & $\begin{array}{l}\text { Type of } \\
\text { finish }\end{array}$ & $\begin{array}{l}\text { Water } \\
\text { level } \\
\text { (feet) }\end{array}$ & $\begin{array}{c}\text { Date water } \\
\text { level } \\
\text { measured }\end{array}$ & $\begin{array}{c}\text { Dis- } \\
\text { charge } \\
\text { (gal/min) }\end{array}$ & $\begin{array}{l}\text { Depth } \\
\text { to } \\
\text { bedrock } \\
\text { (feet) }\end{array}$ & Aquifer & Remarks \\
\hline PL. 456 & 413955071552901 & $07-07-78$ & 158.34 & 19.0 & 1.50 & 14.0 & S & 15.1 & $07-25-78$ & - & $>19$ & SD & $\begin{array}{l}\text { Monitoring well SW7S } \\
\text { installed by F\&O (1979) }\end{array}$ \\
\hline PL 457 & 413955071552902 & $07-07-78$ & 156.75 & 27.0 & 1.50 & 22 & S & 13.6 & $07-25-78$ & - & 27 & SD & $\begin{array}{l}\text { Monitoring well SW7D } \\
\text { installed by F\&O (1979) }\end{array}$ \\
\hline PL 458 & 413953071553001 & $07-25-78$ & 162.3 & 28.0 & 1.25 & 18 & s & 14.3 & $07-25-78$ & - & 28 & $\mathrm{~T}$ & $\begin{array}{l}\text { Monitoring well SW8 } \\
\text { installed by F\&O (1979) }\end{array}$ \\
\hline PL. 459 & 413952071553101 & $07-19-78$ & 161.1 & 21.0 & 1.25 & 11.0 & S & 13.3 & $07-25-78$ & - & $>24$ & $\mathrm{~T}$ & $\begin{array}{l}\text { Monitoring well SW9 } \\
\text { installed by F\&OO (1979) }\end{array}$ \\
\hline PL 460 & 413949071553101 & $07-11-78$ & 277.5 & 32.0 & 1.25 & 25 & x & 22.1 & $07-25-78$ & - & $20+$ & $\mathrm{CB}$ & $\begin{array}{l}\text { Monitoring well SW } 10 \\
\text { installed by F\&O }(1979)\end{array}$ \\
\hline PL 461 & 413949071553102 & $07-14-68$ & 171.22 & 30 & 1.50 & 13.0 & $\mathrm{X}$ & 16.1 & $07-25-78$ & - & 10 & $\mathrm{CB}$ & $\begin{array}{l}\text { Monitoring well SW11 } \\
\text { installed by F\&O (1979) }\end{array}$ \\
\hline PL 462 & 413950071553201 & 07-06-78 & 166.4 & 36.5 & 1.25 & 25.0 & $\mathrm{X}$ & 16.6 & $07-25-78$ & - & 22 & $\mathrm{CB}$ & $\begin{array}{l}\text { Monitoring well SW12 } \\
\text { installed by F\&O (1979) }\end{array}$ \\
\hline \multirow[t]{2}{*}{ PL 463} & 413955071553101 & $07-12-78$ & 155.9 & 28.0 & 1.25 & 18.0 & $\mathrm{~S}$ & 12.8 & $07-25-78$ & - & 36 & $\mathrm{SD}$ & $\begin{array}{l}\text { Monitoring well SW13 } \\
\text { installed by F\&O (1979) }\end{array}$ \\
\hline & & & & & & & & & & & & $\mathrm{T}$ & $\begin{array}{l}\text { Screened in stratified drift } \\
\text { and till }\end{array}$ \\
\hline PL 464 & 413951071553401 & $07-11-78$ & 164.3 & 31.0 & 1.25 & 21.0 & S & 17.6 & $07-25-78$ & - & 40.3 & SD & $\begin{array}{l}\text { Monitoring well SW14 } \\
\text { installed by F\&O (1979) }\end{array}$ \\
\hline \multirow[t]{2}{*}{ PL 465} & 413956071553201 & $07-13-78$ & 155.0 & 31.2 & 1.25 & 21.2 & S & 12.0 & $07-25-78$ & - & 32 & $\mathrm{SD}$ & $\begin{array}{l}\text { Monitoring well SW15 } \\
\text { installed by F\&O (1979) }\end{array}$ \\
\hline & & & & & & & & & & & & $\mathrm{T}$ & $\begin{array}{l}\text { Screened in stratified drift } \\
\text { and till }\end{array}$ \\
\hline PL. 466 & 413955071552801 & $10-11-78$ & 153.29 & 28.0 & 1.50 & 18.0 & $S$ & 8.58 & $12-07.78$ & - & 36.8 & SD & $\begin{array}{l}\text { Monitoring well SW } 16 \\
\text { installed by F\&O (1979) }\end{array}$ \\
\hline & & & & & & & & & & & & $\mathrm{T}$ & $\begin{array}{l}\text { Screened in stratified drift } \\
\text { and till }\end{array}$ \\
\hline PL 467 & 413957071553101 & $10-12-78$ & 150.22 & 25.0 & 1.50 & 15.0 & S & 6.83 & $12-07-78$ & - & $>25$ & SD & $\begin{array}{c}\text { Monitoring well SWI7S } \\
\text { installed by F\&O (1979) }\end{array}$ \\
\hline PL. 468 & 413957071553102 & $10-12-78$ & 150.71 & 47.0 & 1.50 & - & & 6.29 & $12-07-78$ & - & 47 & $\mathrm{~T}$ & $\begin{array}{c}\text { Monitoring well SW17D } \\
\text { installed by F\&O (1979) }\end{array}$ \\
\hline PL 469 & 413953071553401 & $10-12-78$ & 157.49 & 29.0 & - & 19.5 & S & 13.2 & $12-07-78$ & 2.0 & $>31.5$ & SD & $\begin{array}{l}\text { Monitoring well SW18 } \\
\text { installed by F\&O (1979) }\end{array}$ \\
\hline PL 470 & 413909071553801 & $12-04-78$ & 162.75 & 35.1 & 3.0 & 30.1 & S & 10.87 & $04-19-93$ & - & $>36.8$ & SD & $\begin{array}{l}\text { U.S. Geological Survey } \\
\text { observation well }\end{array}$ \\
\hline
\end{tabular}


Wastewater is either collected by a municipal wastewater collection and treatment system or is discharged into individual septic systems. The municipal system incorporates a wastewater-collection system that Lawton Mills also installed at the turn of the century. The system, operated by the town of Plainfield, underwent a major renovation in 1972 that added the ability for tertiary treatment. The areal extent of the wastewater collection system, shown in figure $4 B$, is similar to that of the public water-supply distribution system. The municipal wastewater-treatment facility is located near the junction of Mill Brook and Fry Brook, as shown in figure $4 B$. After treatment, wastewater is discharged to Mill Brook, at a point downstream of Gallup's Quarry. This facility was designed for an average daily flow of $0.75 \mathrm{Mgal} / \mathrm{d}$. The average daily discharge of treated effluent at this facility is currently (1993) about $0.55 \mathrm{Mgal} / \mathrm{d}$, and peak discharges approach design capacity (Jeffery Young, Plainfield Sewer Department, oral commun., 1993). Individual septic systems are assumed to be used for wastewater disposal outside the area served by the municipal wastewater-collection system. In most cases, individuals that are self-supplied by water from wells use septic systems for wastewater disposal.

\section{Land Use}

Historical and current land uses near Gallup's Quarry and in upstream parts of the Mill Brook Basin may have affected the quality of surface water and ground water in the area. Water quality is affected in three primary ways: (1) by direct discharges to surface-water bodies, (2) by infiltration and percolation to the water table of substances that are accidentally spilled on or applied to the land surface, and (3) by subsurface discharges from septic systems and other types of below-ground waste-disposal facilities. The quantities and types of wastes or other materials introduced into surface water or ground water by landuse activities and the characteristics of the hydrologic system will determine the extent, duration, and magnitude of water-quality changes.

The land uses in this area were assessed by examining and interpreting aerial photographs taken during 1941-90 and by field observations made in the summer and fall of 1992. The land use at Gallup's Quarry has been previously described by the U.S. Environmental Protection Agency (1990). The Connecticut Turnpike, also called the Greenwich-
Killingly Expressway, and now Interstate Route 395, was constructed in the late 1950's, and much of the sand and gravel extraction at Gallup's Quarry is believed to have taken place at this time. The upper part of Mill Brook Basin, east of Interstate Route 395, is primarily forested. Agricultural land use was fairly extensive in the 1940's and even in the 1950's, but many fields have reverted to forest since then. There is little large-scale commercial development in this part of the basin. In 1975, the Plainfield Greyhound Racetrack (location 1, fig. 6) was under construction. During 1980-86, the hotel at the intersection of Lathrop Road and Interstate 395 (location 3, fig. 6) was constructed, and during 1986-90, the supermarket located between the dog track and hotel (location 2, fig. 6) was constructed. In 1990, development of a new industrial park off Pratt Road (location 4, fig. 6) began.

Industrial and commercial development on the western side of Interstate Route 395 occurred earlier and is more extensive than development on the eastern side. The building that houses the Agway store (location 5, fig. 6) on the eastern side of Route 12, just north of Mill Brook, was built during 1941-51. Two storage areas have since been added. Shetucket Plumbing and Heating on the eastern side of Gallup's Quarry was constructed in 1951 (location 6, fig. 6); a commercial development on the southeast corner of the intersection of Lathrop Road and Route 12, containing a liquor store, beauty salon, doughnut shop, and delicatessen, was constructed during 1980-86, and a fast-food restaurant was added later (location 7 , fig. 6).

The area north of Gallup's Quarry and Mill Brook has undergone considerable industrial development. Currently (1993), three companies occupy land that drains to Mill Brook-Intermark Flock Corporation (location 8, fig. 6), Davis Pharmaceuticals (location 9, fig. 6), and Safety Kleen Accumulation Center (location 10, fig. 6). Several other industrial and commercial facilities are located nearby on land that has surface drainage to Fry Brook. These include Gallup Lumber Company (location 11, fig. 6), constructed between 1941 and 1951, Garrity Industries, Prestige Brass Works, Pervel Industries, and Staples, all housed in a building built between 1951 and 1965 as an addition to a pre-1941 building that housed the former InterRoyal Company (location 12, fig. 6). The Village Wastewater Treatment facility, constructed prior to 1941, that serves as the municipal wastewater treatment system is also located in this area (loca- 


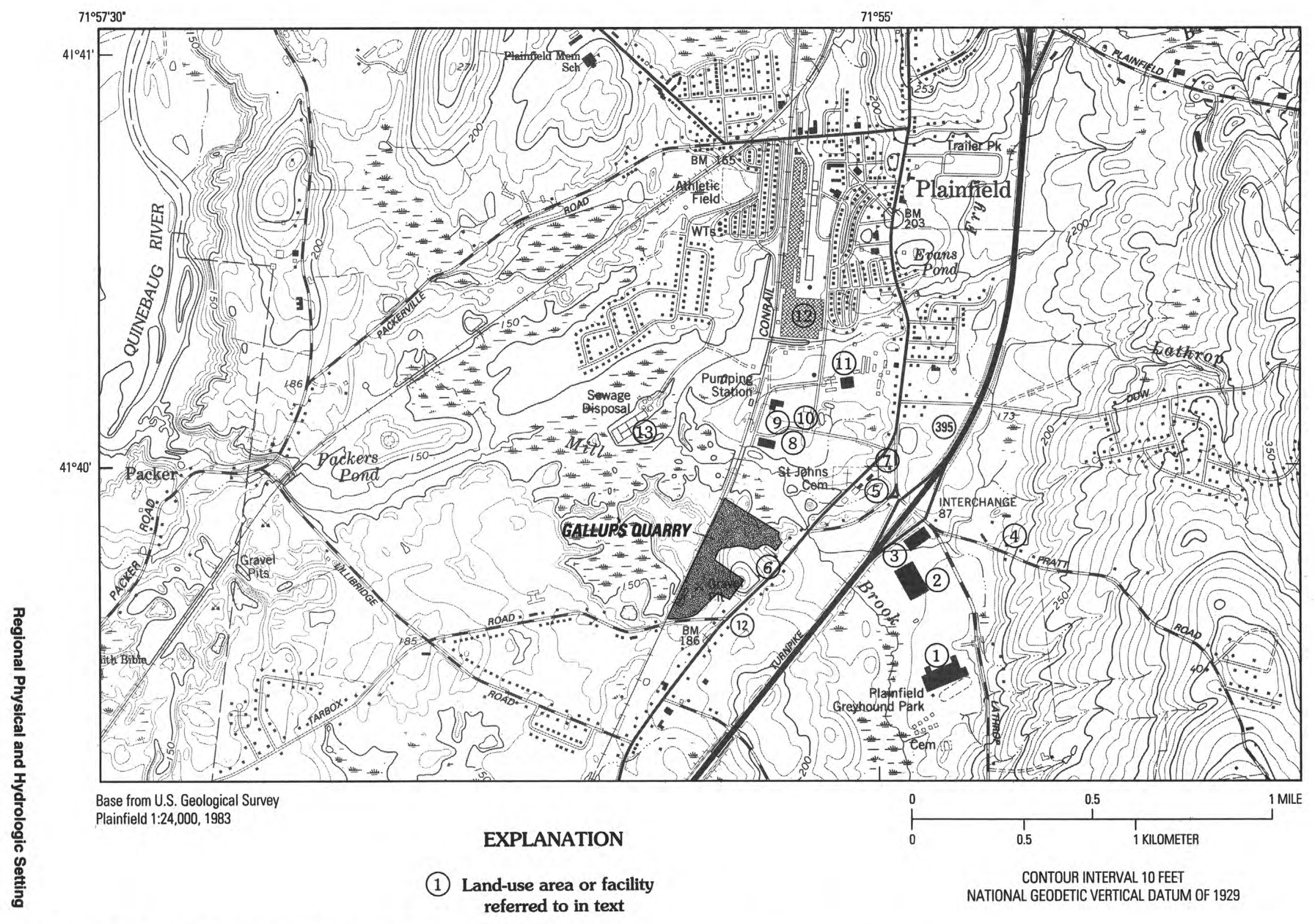

Figure 6. Selected land-use activities in the Gallup's Quarry area. 
tion 13, fig. 6). In addition, numerous small cottage industries and businesses are present but are not shown in figure 6.

\section{REGIONAL GEOHYDROLOGY}

\section{Geohydrologic Units}

Three principal geohydrologic units underlie eastern Connecticut (Randall and others, 1966, pl. B), all of which are present in the Mill Brook Basin. These units include stratified drift, till, and crystalline (metamorphic) bedrock. Stratified drift and till are glacial sediments of late Pleistocene age that lie directly on the bedrock surface. Stratified drift is further subdivided, on the basis of texture, into coarsegrained units (dominantly fine to very coarse sand and gravel) and fine-grained units (dominantly very fine sand, silt, and clay). Postglacial alluvium and swamp deposits are included within the stratified-drift unit.

The surficial geology of the Plainfield quadrangle has been mapped at 1:24,000 scale (Stone and Randall, 1977) and placed in a larger regional context on the "Surficial Materials Map of Connecticut" (Stone and others, 1992). A modified surficial geologic map (Stone and Randall, 1977) is shown in figure $7 A$. The bedrock geology of the Plainfield quadrangle has been mapped at 1:24,000 scale (Dixon, $1965 ; 1968)$ and placed in a larger regional context on the "Bedrock Geological Map of Connecticut" (Rodgers, 1985). The regional bedrock geology of the Plainfield quadrangle is shown in figure 8 . The mineralogy of glacial sediments in the Quinebaug Valley near Gallup's Quarry was studied by Force and Stone (1990). In addition, other investigations have added to an understanding of the age and geologic history of bedrock in eastern Connecticut (Zartman and Naylor, 1984; Wintsch and Sutter, 1986).

\section{Stratified Drift}

Stratified drift deposited by glacial meltwater during retreat of the Late Wisconsinan ice sheet overlies till and bedrock throughout the Quinebaug Valley lowland, as well as in smaller valleys in the uplands. This material consists of gravel, sand, silt, and clay carried away from the ice front by meltwater streams, which commonly flowed directly or indirectly into glacial lakes. Coarse-grained, poorly sorted, and relatively angular gravels were deposited at, and proximal to, the ice front. This material was commonly laid down on top of ice at the glacier margin. Subsequent melting of the ice produced "collapsed" ice-contact scarps and kettle holes in these proximal deposits. Finer grained and better sorted gravel and sand were deposited farther away from the ice margin, commonly in deltas that prograded into glacial lakes. Well-sorted, very fine sand, silt, and clay settled out as bottom sediments in these lakes. These "packages" of contemporaneously deposited stratified drift that grade from coarse grained near the ice margin to fine grained in areas distal from the ice are called morphosequences (Koteff and Pessl, 1981; Stone and others, 1992). Morphosequences are commonly 0.5 to $1 \mathrm{mi}$ long and are present up the valley in shingled form - the coarse-grained, collapsed, ice-contact, northern part of one sequence is overlain by the fine-grained distal end of the next sequence to the north. (See figs. $7 A$ and $7 B$.) This shingled relation between morphosequences occurs at, and northwest of, Gallup's Quarry and is the result of systematic northward retreat of the ice sheet during deglaciation.

The highest level (altitude) to which the stratified-drift sediments were deposited was controlled by the local base level of the meltwater streams; local base level was most commonly a glacial lake to which the streams drained. In the southern part of the Quinebaug Valley lowland, glacial Lake Quinebaug controlled the level of meltwater deposition (Stone and Randall, 1977). This lake was impounded by a glacial-drift dam that filled the bedrock gorge of the present Quinebaug River south of Jewett City (about $10 \mathrm{mi}$ south of Gallup's Quarry). The water level of the lake was controlled by a spillway (at an altitude of $134 \mathrm{ft}$ ) adjacent to the gorge. The glacial lake in the Quinebaug lowland lengthened as the glacier margin retreated northward through the area. At the end of glacial retreat and meltwater deposition, the lake was largely filled by the deltas and lake-bottom sediments that underlie the valley today. (See fig. 7.) The altitude of the paleo-water level of the lake is recorded by the unconformable contact between flat-lying, gravelly, fluvial topset beds and dipping, sandy, subaqueous foreset beds in the deltas. The altitudes of topsetforeset contacts in deltas of glacial Lake Quinebaug increase at a rate of $4.7 \mathrm{ft} / \mathrm{mi}$ in a north-northwest (NNW) direction, as a result of postglacial tilting of the Earth's crust. Near Gallup's Quarry, the paleo-lake level is 166 to $171 \mathrm{ft}$ in altitude. The topset-foreset contact beneath the flat, noncollapsed parts of delta 
surfaces commonly marks the boundary between gravel or sand and gravel beds and lower sand and silty sand beds, as shown in geologic sections in figure $7 B$.

The coarse-grained stratified drift in the Quinebaug Valley lowland consists predominantly of a series of ice-marginal deltaic morphosequences laid down sequentially northward in the lake. Fine-grained stratified drift consists of lake-bottom deposits laid down in deeper parts of the lake in front of the deltas. At the southern end of Gallup's Quarry, as in many parts of the Quinebaug Valley, successive deltas were built up against earlier ones, so that the surface gradient of the stratified-drift deposit is continuous from one deltaic morphosequence to the next (fig. 7 and pl. 2). In other places, low areas underlain by lakebottom sediments separate the deltaic sequences. This is the situation northwest of Gallup's Quarry where, at and north of the contact between two successive deltaic sequences, collapsed, ice-proximal beds of the first delta are overlain by finer grained, ice-distal sediments of the next sequence to the north.

Drainage of glacial Lake Quinebaug occurred when erosion of the glacial-drift dam allowed gradual lowering of the lake water levels. Postglacial streams incised the glacial sediments as an integrated drainage system developed. Rivers and streams incised rapidly, and modern flood-plain surfaces developed early after lake drainage. Alluvium underlying the flood-plain surfaces consists of relatively thin sand, gravel, and silt (reworked glacial deposits) with minor amounts of organic matter; thicker glacial deposits generally underlie the alluvium. As postglacial vegetation moved into the region, organic debris accumulated as peat and gyttja (freshwater organic-rich mud) in lowlying, poorly drained, closed basins created by melting of ice blocks. This peat and gyttja is as much as $30 \mathrm{ft}$ thick in the large kettle-hole swamps.

Thick and extensive deposits of saturated, coarse-grained stratified drift are the most productive aquifers in the area. These aquifers are capable of storing and transmitting large quantities of ground water through interconnected pore spaces and, in most areas, they are unconfined and hydraulically connected to adjacent surface-water bodies. The average transmissivity of stratified-drift aquifers in eastern and central Connecticut generally ranges from about 1,500 to $12,500 \mathrm{ft}^{2} / \mathrm{d}$ (Melvin, 1974; Mazzaferro and others, 1979; Melvin and Bingham, 1991). The saturated thickness of these aquifers ranges considerably, but the maximum is generally 40 to $120 \mathrm{ft}$.
The thick, saturated stratified drift in the central part of the Mill Brook Basin, extending from Lillibridge Road north across Gallup's Quarry and into Fry Brook and Horse Brook Valleys (fig. 7A), is considered a major stratified-drift aquifer. The coarsegrained sediments that are at land surface in the northern and southern parts of this area are deltaic. The relatively low and flat intervening area, north and northwest of Gallup's Quarry and extending across Mill Brook as far as the ice-marginal deltas designated $\mathrm{d}_{4}$ and $\mathrm{d}_{5}$ (fig. $7 A$ ), is partly underlain by fine-grained lake-bottom sediments, as shown in figure $7 B$. The greatest saturated thickness, more than $80 \mathrm{ft}$, is largely within this area. Randall and others (1966, table 34 and pl. D) identified this aquifer area as 1 of 29 within the Quinebaug River Basin that were especially favorable for ground-water development. The longterm yield estimate for this area of $2.3 \mathrm{Mgal} / \mathrm{d}$ is based on annual rates of recharge and estimated potential induced infiltration from streams, as described by Randall and others (1966, p. 85-90). The Gallup Water Service Company well field taps buried coarsegrained stratified drift (as much as $43 \mathrm{ft}$ thick) in the northern part of this area, and one of the company wells (USGS well Pl 185 shown in figs. 5 and $7 B$ ) was tested at $1,500 \mathrm{gal} / \mathrm{min}$ in 1961 (Thomas and others, 1966 , p. 61). Parts of this aquifer where fine-grained sediments overlie coarse-grained sediments are possibly confined or semiconfined.

Saturated, coarse-grained, stratified drift is common in upstream parts of Mill Brook Basin. East of Interstate Route 395 it forms a band 0.2 to almost $0.5 \mathrm{mi}$ wide that underlies Mill Brook Valley and is bordered on the east and west by steep, till-mantled bedrock uplands that extend to the basin drainage divide. The saturated thickness of coarse-grained stratified drift in this part of the Mill Brook Valley is generally greater than $10 \mathrm{ft}$ but less than $40 \mathrm{ft}$ (Randall and others, 1966, pl. B).

Natural ground-water recharge, derived from precipitation, has been determined by tritium measurements to average greater than or equal to $16.7 \mathrm{in} / \mathrm{yr}$ and $26.1 \mathrm{in} / \mathrm{yr}$ at two sites in sand and gravel (stratified drift) areas of Nantucket, Massachusetts, during 1964-83 (Knott and Olimpio, 1986, p. 22). Measured recharge rates calculated at Nantucket are equal to 44 and 68 percent of the average annual precipitation. When these percentages are applied to the Gallup's Quarry area (also underlain by stratified drift) where estimated average annual precipitation was 53 in. during 1978-91, the resulting average recharge is 23.3 and $36 \mathrm{in} / \mathrm{yr}$, respectively. For this study, we 


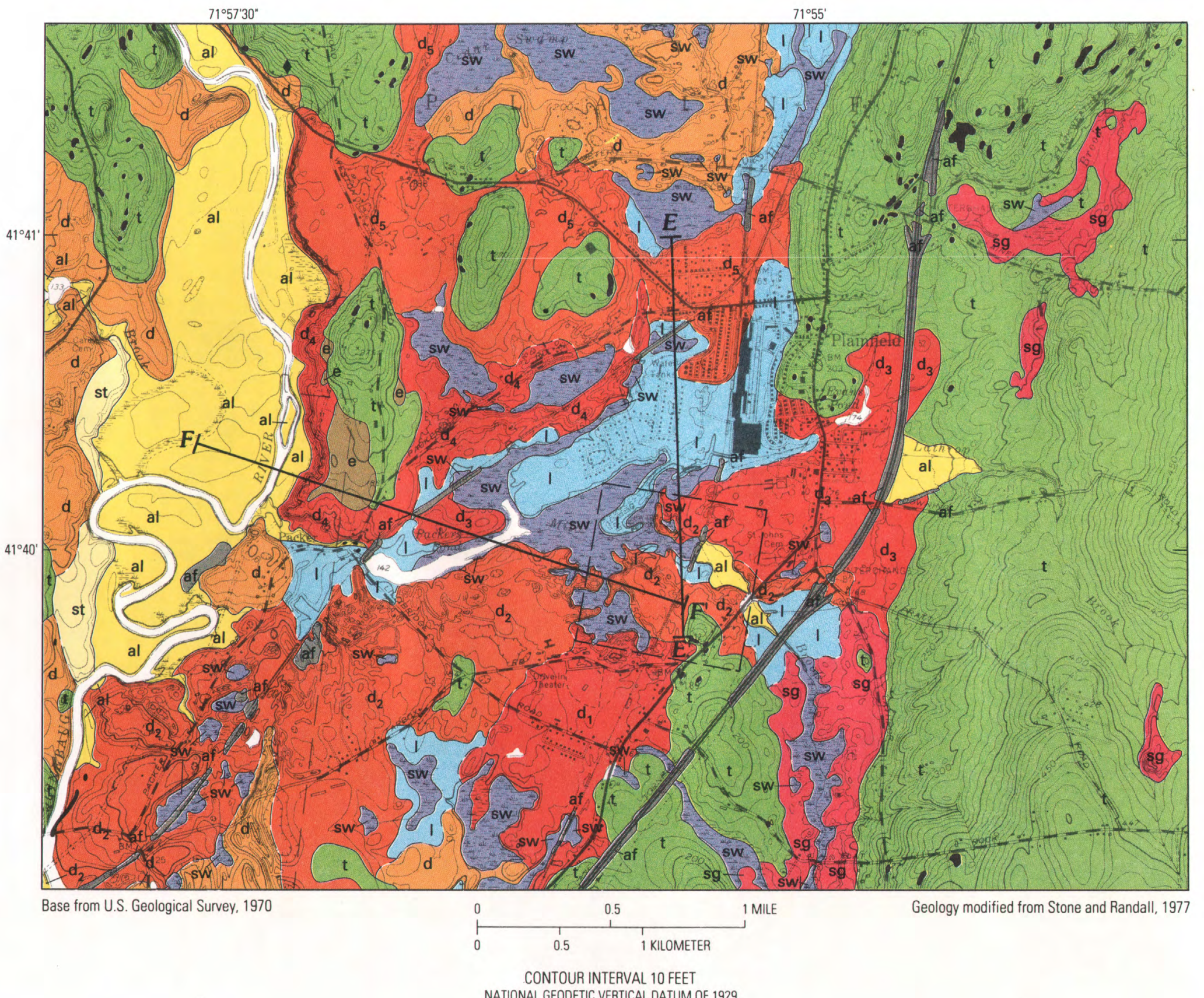




\section{EXPLANATION}

\section{POSTGLACIAL DEPOSITS}

Artificial fill-Compacted fill, generally quarried from glacial stratified deposits, used beneath highways, railroads, and small dams; the body of artificial fill on the Quinebaug River flood plain is compacted trash mixed with sand and gravel at a municipal landfill

al Flood-plain alluvium-Sand, gravel, and silt with minor organic material on modern flood plain of Mill Brook and Quinebaug River; generally less than 5-10 feet thick along Mill Brook, and as much as 20 feet thick along the Quinebaug River. Alluvium overlies thicker glacial materials

Swamp deposits-Peat and muck (gyttja) with minor amounts of sand, silt, and clay; may be as much as $\mathbf{3 0}$ feet thick in the larger kettle-hole swamps. Swamp deposits overlie thicker glacial materials

Stream-terrace deposits-Sand and pebble gravel generally less than 15 feet thick on terraces along the Quinebaug River cut into higher level Lake Quinebaug deposits

\section{GLACIAL DEPOSITS}

e Eolian dune deposits-Well-sorted, fine to medium sand deposited by strong, early postglacial northwesterly winds in local dunes where sand may be as much as 15 feet thick; a 1- to 3-feet thick eolian sand blanket is present nearly everywhere overlying the glacial deposits but is not mapped

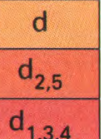

Ice-marginal deltas of glacial Lake Quinebaug - Coarse gravel and sand, commonly beneath collapsed landforms and in deformed and faulted beds in northern (ice-proximal) parts of each delta. Cobble to pebble gravel and sand generally less than 15 feet thick overlies thicker sand deposits in the noncollapsed, flatter areas in the southern parts of each delta. Fine-grained deposits may be present beneath the sand in the southernmost parts of each delta sequence. Numbers indicate order of deposition for selected deltas

I Lake-bottom deposits of glacial Lake Quinebaug - Very fine sand, silt, and clay at depth, upper few feet locally is medium to coarse sand with some granules and pebbles

Meltwater deposits in Mill Brook Valley and other upland valleys-Collapsed sand and grave in kettled areas and sand and gravel overlying sand in predominantly deltaic sequences that filled a series of small ice-dammed lakes in the Mill Brook Valley and several smaller, higher valleys to the east

$\mathrm{t} \quad$ Till-nonsorted, generally compact mixture of stones in a sandy matrix that contains less than 25percent silt and clay; laid down directly by glacial ice. Diamond symbol $\downarrow$ indicates Black Hill lower till locality

MAP SYMBOLS

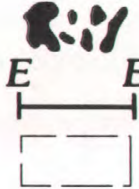

Bedrock outcrops

Line of section (Section shown in figure 7b.)

Area of Gallup's Quarry area map (See plate 2.)

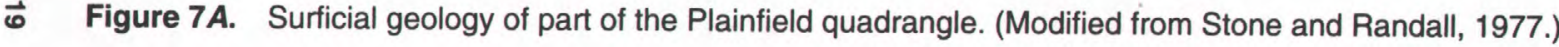


250
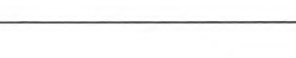

을

$150-$

West DATUM IS SEA LEVEL

0

1.000

2,000 FEET
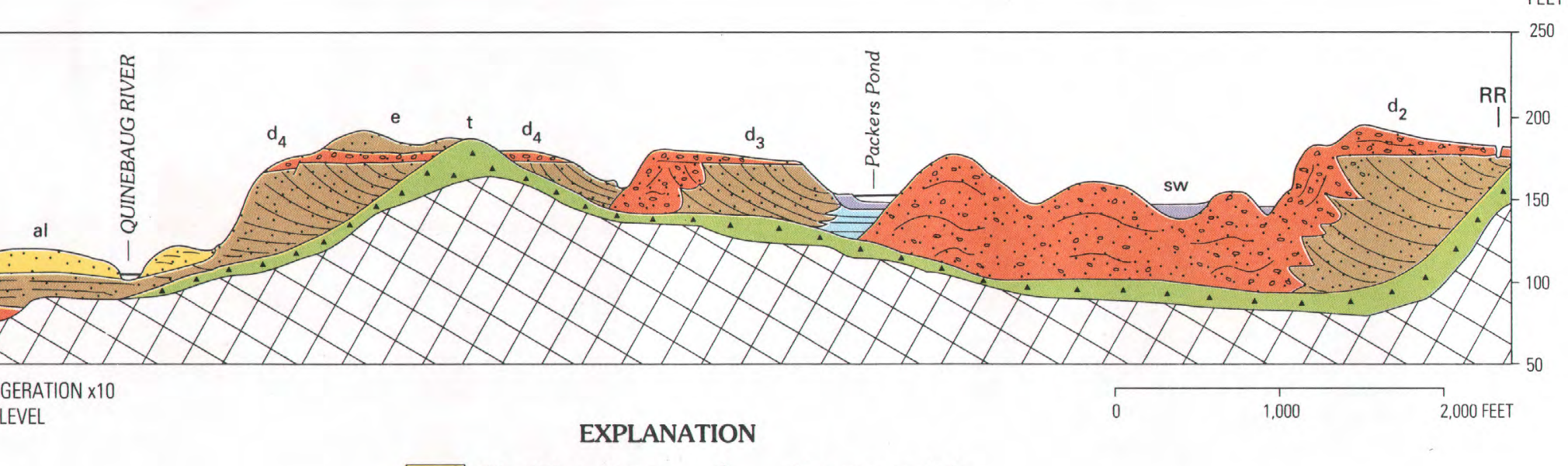

离

๖̊ำ

50

VERTICAL EXAGGERATION $\times 10$

DATUM IS SEA LEVEL

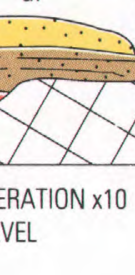

\section{EXPLANATION}

Map-unit symbol

\begin{tabular}{|c|c|}
\hline & Swamp deposits \\
\hline 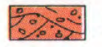 & Sand and gravel \\
\hline 722 & Sand \\
\hline 司 & Fines \\
\hline$\therefore .4$ & Till \\
\hline$\infty$ & Bedrock \\
\hline
\end{tabular}

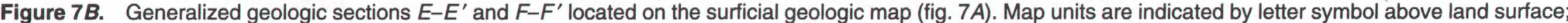
textures are shown by color and pattern; bedding is shown schematically. These geologic sections are based on geologic interpretation of all exposures of surficial materials, their topographic expression, and all available subsurface information. The distribution of subsurface (buried) coarsed-grained deposits north of Gallup's Quarry on geologic section $E-E^{\prime}$, indicated by dotted contacts, may be more or less continuous than shown in areas for which subsurface data are not available. 


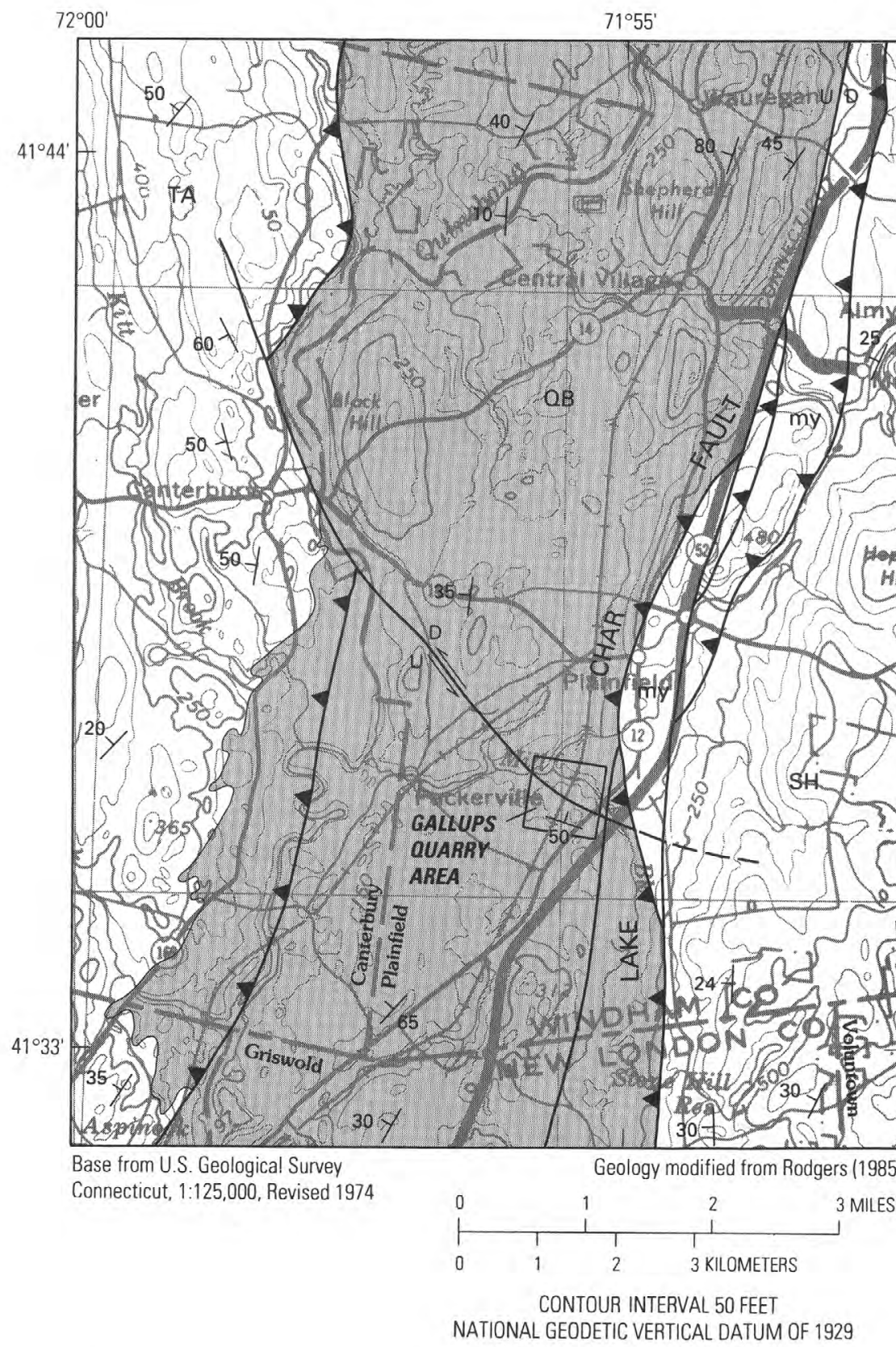

\section{EXPLANATION}

TA Tatnic Hill Formation

$\mathrm{OB}$ Quinebaug Formation

SH Hope Valley Alaskite

Gneiss-Avalonian rock

my Blastomylonite-Along Lake Char fault zone

$-50 \quad$ Strike and dip of foliation

A Thrust fault-Teeth on upper plate

U High-angle fault-Arrows show relative motion. U-upthrown side; D-downthrown side

Figure 8. Generalized bedrock geology of the Plainfield quadrangle.

consider the average of these two values, or about $30 \mathrm{in} / \mathrm{yr}$, to be the long-term average recharge rate for the stratified drift in the Gallup's Quarry area. This estimate is similar to the estimate of long-term groundwater runoff for a stratified-drift area in Connecticut made using the regionalization technique described by Mazzaferro and others (1979). Ground-water runoff is considered to be a conservative estimate of groundwater recharge (Randall and others, 1966; Cervione and others, 1972), which indicates that $30 \mathrm{in} / \mathrm{yr}$ is a reasonably accurate estimate.
Till

Glacial tills laid down during two separate episodes of continental glaciation are present throughout southern New England, and both are locally present in the Plainfield area. The lower (older) till is discontinuous and generally is present only in areas of thick till accumulation. An exposure of this till at the southern end of Black Hill, about $2.5 \mathrm{mi}$ northwest of Gallup's Quarry, was described by Stone and Randall (1977), who also reported lower till along Interstate Route 395 
just east of the quarry. At Black Hill, the lower till is a brown to olive-brown, very compact mixture of pebbles, cobbles, and few boulders in a sandy matrix that contains 42-percent silt and clay; it is stained throughout with iron oxide. The upper part of the lower till section contains distinct subhorizontal fissility with parting planes spaced at 0.2 -in. intervals; this fissility and a less well-developed, subvertical, iron- and manganese-stained joint system give the lower till an angular blocky structure.

The upper (younger) till was deposited by the last (Late Wisconsinan) ice sheet. Upper till exposures in the Plainfield area generally reveal compact, gray to gray-brown, non-oxidized, stony till with a sandy matrix. This till is interpreted to be a lodgment facies and exhibits a weakly developed subhorizontal fissility. Where the upper till overlies the lower till, as at Black Hill, discrete pieces of the oxidized lower till occur as blocks within the matrix of the non-oxidized upper till. The matrix of the upper till derived from fine-grained rock units in the Quinebaug lowland has a higher silt content than the matrix of the upper till derived from coarse-grained rock units in the uplands.

Till is an extensive and important geohydrologic unit in eastern Connecticut. It underlies most upland areas in the Mill Brook Basin and extends beneath the stratified drift in the lowlands. Although it is not a major aquifer because of small saturated thickness and low hydraulic conductivity, till is nevertheless an important unit because it affects the circulation of ground water, particularly rates of recharge to and discharge from underlying bedrock aquifers. Recharge rates to till and bedrock have not been measured individually, but aggregate rates to both units have been estimated and are discussed in the section "Bedrock."

Water is generally transmitted through interconnected pores in the till matrix, but some tills in Connecticut contain closely spaced joints or lenses of stratified sediment that also can transmit water (Melvin and others, 1992a). The presence of secondary openings caused by subhorizontal fissility and vertical joints in till exposures near Gallup's Quarry has already been noted. Information on the hydraulic properties of tills in eastern Connecticut is sparse. The total thickness of till is highly variable in this area but generally is less than $15 \mathrm{ft}$; the saturated thickness, known at only a few isolated locations, is even less. Areas where till is thicker than $15 \mathrm{ft}$ (up to $45 \mathrm{ft}$ thick at USGS well P1 200, Thomas and others, 1966, p. 51) are known or inferred to be present locally in the Mill Brook Basin (Stone and others, 1992). The horizontal hydraulic conductivity of tills in eastern Connecticut are commonly 0.04 to $24 \mathrm{ft} / \mathrm{d}$ on the basis of singlewell response tests (slug tests) conducted by Torak (1979) and Pietras (1981). Laboratory-determined values of vertical hydraulic conductivity extend over a similar range (Melvin and others, 1992a, table 3). Laboratory-determined values of porosity and specific yield of 15 samples of tills from southern New England derived from crystalline bedrock ranged from 22.1 to 40.6 percent and from 3.9 to 31.2 percent, respectively (Melvin and others, 1992a, table 3 ). These values pertain to the till matrix and may not be representative of the bulk mass of till if fractures were present.

\section{Bedrock}

Gallup's Quarry, and most of the Quinebaug Valley lowland to the west of this pit, is underlain by dark, fine- to medium-grained hornblende gneiss, biotite gneiss, and amphibolite of the Quinebaug Formation (fig. 8). These rocks have a lower quartz and feldspar content than the gneisses in the uplands to the east and west and are, consequently, less resistant to erosion. The rocks of the Quinebaug Formation were originally deposited (probably in Proterozoic time, 700 million years ago) in an oceanic environment as well-layered volcanic tuffs and sediments. They were subsequently metamorphosed to sillimanite-muscovite grade, strongly folded, faulted, and cataclastically deformed.

The rocks in the uplands to the east of the Quinebaug Formation are light-colored, medium- to coarse-grained granitic gneiss and quartzite of the Hope Valley Alaskite Gneiss and Plainfield Formation. These rocks, referred to as "Avalonian terrane" (Rodgers, 1985), are also of Proterozoic age but have a different depositional and deformational history than rocks of the Quinebaug Formation or the Tatnic Hill Formation farther to the west.

The boundary between the Quinebaug Formation and the Hope Valley Alaskite Gneiss and Plainfield Formation is a major north-south trending thrustfault zone, which lies 0.3 mi east of Gallup's Quarry, along the valley of Mill Brook; the zone extends northward through the village of Plainfield (fig. 8). This west-dipping fault zone, called the Lake Char fault, continues southward and westward and becomes the north-dipping Honey Hill fault zone in southcentral Connecticut. Post-metamorphic, tectonic deformation of the rocks on both sides of the fault 
zone associated with thrust faulting includes intense mylonitization (microbrecciation) and cataclasis (fracture deformation); as a result, much of the lower (eastern) member of the Quinebaug Formation (the bedrock type at Gallup's Quarry) is mortar gneiss, mylonite gneiss, and blastomylonite.

The rock units of the Quinebaug Formation (in the lowland) and the Tatnic Hill Formation (in the uplands to the west) strike north-northeast (NNE); they are locally cut and offset by high-angle faults, the most obvious of which trend northwest to westnorthwest (WNW) (fig. 8). These high-angle faults are younger than the Lake Char-Honey Hill thrust faults. They have been mapped from outcrop exposures and offsets in aeromagnetic anomalies (Boynton and Smith, 1965) that mark continuous strike ridges within the bedrock. These are brittle faults commonly characterized by open fractures filled with secondary quartz veins or fault gouge material consisting of mechanically ground and (or) weathered rock fragments.

One of these high-angle faults reportedly passes through the Gallup's Quarry area (Dixon, 1965). In the uplands to the west of the Quinebaug River, this fault trends NNW and offsets rock units within the Tatnic Hill Formation. On the western side of the lowland, the trend of the fault becomes NW, and outcrops on both sides of the fault show offsets in the upper member and the Black Hill Member of the Quinebaug Formation. Within the Quinebaug Valley lowland, the fault curves to a WNW trend and, due to the thickness of glacial sediment cover, can be located only by offsets in aeromagnetic anomalies (Boynton and Smith, 1965). In the uplands underlain by Avalonian rocks just east of Gallup's Quarry, the distribution of several bedrock water wells with unusually high yields from "a rusty quartz vein" (Randall and others, 1966; Dixon, 1968) indicates a fracture zone that trends N. $70^{\circ} \mathrm{W}$. and dips steeply northward. It is inferred that this fracture zone is a continuation of the highangle WNW-trending fault that passes through Gallup's Quarry (fig. 8) and continues across the Lake Char thrust-fault zone and into the Avalonian rock units to the east.

All crystalline bedrock outcrops in eastern Connecticut, including those in the study area, display numerous fractures (joints) with no apparent fault offset. Many are relatively closed joints, whereas others are open by a few hundredths or tenths of an inch. The latter types may be important conduits for the flow of water through bedrock. Most of these fractures reportedly occur in the upper 200 to $500 \mathrm{ft}$ of the bedrock, and they are believed to decrease in number and size with depth (Randall and others, 1966; Trainer, 1987). Faults can extend much deeper, and Paillet (1985, p. 28) questioned the general assumption that the number of open fractures decrease with depth. Many of the outcrops near Gallup's Quarry exhibit subhorizontal joints spaced several feet apart that, in general, conform to the bedrock surface. Also common are near-vertical joint sets with dominant WNW trends and less prominent NE trends.

Crystalline bedrock is a major aquifer that is tapped by almost all domestic and commercial wells in this area. Yields of individual wells are typically 3 to $20 \mathrm{gal} / \mathrm{min}$, higher than average well yields in this part of eastern Connecticut have been ascribed to wells that intersect fault zones (Randall and others, 1966, p. 63). Ground-water flow in the crystalline bedrock is almost entirely through networks of interconnected fractures, and the rock matrix is virtually impermeable (Randall and others, 1966, table 25). The hydraulic properties of crystalline-bedrock aquifers in Connecticut have not been studied extensively, and consequently, the properties are poorly defined. Randall and others (1966, p. 63) estimated the average hydraulic conductivity of the bulk mass of fractured crystalline bedrock in the Quinebaug River Basin from specificcapacity data. They computed an average hydraulic conductivity of $0.5 \mathrm{ft} / \mathrm{d}$ from specific capacities of 247 wells. Natural ground-water recharge in the till and bedrock areas has not been directly measured. Conservative estimates, made from hydrologic budgets of several basins underlain entirely, or almost entirely, by these units (Cervione and others, 1972; Mazzaferro and others, 1979), indicate the combined natural recharge to till and bedrock is equal to about 30 percent of the total runoff. The total average annual runoff for this part of eastern Connecticut for the period 1978-91 was estimated to be about 32 in. (p. 6). Natural recharge to till and bedrock, therefore, would average about $9.6 \mathrm{in} / \mathrm{yr}$ for this period $(0.30 \times 32 \mathrm{in} / \mathrm{yr})$.

\section{Circulation of Ground Water}

The water that percolates into the ground and reaches the water table flows through one or more of the geohydrologic units before it is discharged from the saturated zone. The general pattern of groundwater circulation within a typical Connecticut drain- 
age basin, such as the Mill Brook Basin, has been described by several investigators (Randall and others, 1966; Cervione and others, 1972; Thomas and others, 1967). The moderate topographic relief and the relatively high recharge from precipitation produce a water-table configuration within these basins that is commonly described as a subdued reflection of the land surface. Water that percolates into the saturated zone in the uplands moves downgradient both horizontally and vertically toward sites of natural ground-water discharge, such as streams and swamps. The lowest discharge point is the perennial stream that drains the main valley. In upland areas, and particularly near upland drainage divides, there is a significant downward vertical component to the groundwater flow. Similarly, on the lower parts of hills and in valleys, there may be a significant upward vertical component to the ground-water flow. Most of the circulation takes place in the upper part of the saturated zone, which is generally within $300 \mathrm{ft}$ of the land surface. Superimposed on this general pattern of circulation are local ground-water flow systems. These local or minor flow systems are generally associated with small tributary streams (commonly intermittent) or swamps and ponds. They differ in both areal extent and depth and may be permanent or transient features.

Ground water that does not evaporate or transpire by vegetation leaves the drainage basin as discharge to streams or as underflow through permeable deposits that underlie the mouth of the basin. The possibility of deeper regional flow, in which water in the crystalline bedrock flows beneath the Mill Brook drainage divide toward the Quinebaug River, although small, cannot be excluded. Such regional flow would be most likely in the central and lower parts of the basin where relief is relatively low and the crystalline bedrock is extensively fractured.

\section{GEOHYDROLOGIC SETTING OF THE GALLUP'S QUARRY AREA}

The distribution, thickness, and texture of geohydrologic units within the study area were determined by geologic mapping, interpretation of the published logs from wells and test pits (Fuss and O'Neill, 1979), and analyses and interpretation of ground-penetrating radar (GPR) data collected along the survey lines shown on plate 1 . The application of GPR methods in geohydrologic studies and surficial geologic mapping has been described by Beres and
Haeni (1991). This method produces continuous highresolution profiles of the subsurface similar to those produced by continuous seismic-reflection surveys. It was not possible to enhance the unprocessed radar records through data processing because a software problem affected the recording of the digital data. Three test holes were drilled to confirm the depth to major stratigraphic horizons interpreted from the radar records. Paper copies of the radar images are on file at the U.S. Geological Survey, Hartford, Conn.

Conceptualized paths of ground-water flow were derived from data on horizontal and vertical hydraulic gradients documented in Fuss and O'Neill (1979) and from knowledge of ground-water flow systems in hydrologically similar areas elsewhere in Connecticut. Streamflow information was estimated by regionalization techniques described in previous USGS reports (Thomas, 1966; Cervione and others, 1982). The discharge of Mill Brook was also measured several times to define the range of flow during this study.

\section{Geohydrologic Units}

Stratified-drift deposits overlie till and bedrock in most of Gallup's Quarry and the area to the north and west of the site. From 10 to $20 \mathrm{ft}$ of sand and gravel was removed from many parts of the Gallup property prior to waste-disposal activities. The texture of the stratified deposits ranges from extremely coarse, boulder-cobble gravel to very fine sand and silt; textural units are shown on the geologic map of the study area (pl. 2 , in pocket). In most places, changes in textural units occur vertically as well as laterally. The geologic map describes the general vertical textural variations by the use of "stacked" unit symbols such as $\mathrm{sg} / \mathrm{s}$ (indicating sand and gravel overlying sand) and s/f/sg (indicating sand overlying fines overlying sand and gravel). These vertical relations can also be seen in the geologic sections on plate 2 . Small-scale variations in grain size commonly are present within the mapped textural units. These small-scale heterogeneities are likely to affect the distribution and transport of contaminants.

At the northern end of Gallup's Quarry, finegrained deltaic sands and lake-bottom silts and clays associated with deltaic sequence $d_{3}$ to the north (fig. 7 , geologic section $E-E$ ) overlie collapsed coarse gravels and sand of the ice-contact part of deltaic sequence $d_{2}$. Boulder-cobble gravel of this sequence, 
deposited at the ice margin, is exposed in excavated scarps just south of the primary barrel disposal pit area. This very coarse-grained gravel is present along the former ice-margin position to the east and west of the quarry as well; its surface slopes northward beneath the finer grained sediments at the northern end of the Gallup property (see geologic sections on pl. 2). It can be inferred to be continuously or discontinuously present in the subsurface beneath fine-grained sediment of deltaic sequences $d_{3}$ and $d_{4}$ to the north (fig. $7 B$ and pl. 2). In the southern part of Gallup's Quarry, deltaic sands and lacustrine silts up to $90 \mathrm{ft}$ thick are present and at the extreme southern end of the Gallup property, they overlap coarser materials of deltaic sequence $d_{1}$. (See geologic section $A-A^{\prime}$ on pl. 2.)

Swamp deposits and flood-plain alluvium overlie glacial meltwater deposits locally to the north and west of Gallup's Quarry. About 3 to $15 \mathrm{ft}$ of peat and organic muck with lesser amounts of sand, silt, and clay underlie large kettle-hole swamps. Sandy to silty alluvium with local gravelly beds and minor organic matter underlies the flood plain of Mill Brook and is probably less than 3 to $6 \mathrm{ft}$ thick.

Till blankets the bedrock surface and underlies the stratified drift over most of the area; it is up to $25 \mathrm{ft}$ thick and is exposed at an altitude of $190 \mathrm{ft}$ above sea level on the hill in the southeastern part of Gallup's Quarry (hereinafter referred to as the till-bedrock hill). Till is not presently exposed in a vertical section anywhere in this area, but the well and test-pit logs described by Fuss and O'Neill (1979) indicate that the till is a dense, gray, stony material with a silty, sandy matrix. This till is believed to be the lodgment facies of the upper till. It is possible that the upper till in the study area locally overlies very compact, oxidized, and jointed lower till (see previous description), but no direct evidence for this exists. The extent and thickness of till at Gallup's Quarry, as interpreted from well logs, test borings, and GPR lines, are shown on geologic sections $A-A^{\prime}, B-B^{\prime}, C-C^{\prime}$ and $D-D^{\prime}$ (pl. 2). The seepage bed used for waste disposal (pl. 1) was constructed in till after thin (less than 15-ft-thick) pebble-cobble gravel was removed during sand and gravel extraction.

Bedrock near Gallup's Quarry lies at depths of 0 to $90 \mathrm{ft}$ below the present land surface (pl. 2). Bedrock crops out at the surface at altitudes of 200 to $210 \mathrm{ft}$ above sea level on the southwestern side of the till-bedrock hill. From this high point, the bedrock surface slopes north, northwest, west, and southwest beneath Gallup's Quarry. The outcrop is dark-greenish gray, very fine-grained chloritic blastomylonite. It is extremely hard and brittle and is thinly laminated with diffuse, discontinuous white streaks, which are partly feldspathic. Formerly hornblende gneiss, this rock has undergone intense cataclasis and mylonitization associated with the Lake Char thrust faulting, and as a result, hornblende has been altered to chlorite and plagioclase to sericite. The structural trend (strike of cataclastic foliation) in this outcrop is WNW with a NNE dip direction. This structural trend differs from the general NNE structural trend in nearby bedrock outcrops exposed at roadcuts at interchange 88 (Route 395).

The change in structural trend likely results from an offset along the WNW-trending fault that is mapped through Gallup's Quarry (Dixon, 1965; Rodgers, 1985) (fig. 8). Although not exposed, the WNW-trending, northward-dipping fault appears to be visible on GPR line R1 (fig. 9). The strong radar reflection from what is likely a fault may be related to the presence of sorbed inorganic contaminants, faultgouge material, or other infilling along the fault. This interpretation of the GPR record has not been further investigated by test drilling to confirm the altitude of the bedrock surface at this point or the presence of fault-gouge material along the fault plane. The traces of the northward-dipping fault near station 25 on GPR line R1 have been plotted on geologic section $A-A^{\prime}$ (pl. 2). The dip of the fault, determined after migration and correction for vertical and horizontal scale differences, is about $38^{\circ}$. Because the trend of the GPR line is nearly normal to the mapped strike of the fault (Dixon, 1965), the true dip of the fault may be only slightly greater than $38^{\circ}$. Projection of the fault plane beneath nearby wells SW 10 and SW 11 indicates that the fault would be present at depths of $94 \mathrm{ft}$ and $53 \mathrm{ft}$ below the bedrock surface, respectively. Neither of these wells is deep enough to intersect the projected fault plane. The 8-in.-wide fracture reported in well SW10 at $11 \mathrm{ft}$ below the top of the bedrock surface (Fuss and O'Neill, 1979) may possibly be expressed as the southward-dipping reflector present at station 28 on GPR line R1 (fig. 9).

No direct measurements of hydraulic conductivity, storativity, or porosity have been made at Gallup's Quarry for any geohydrologic units. Typical values of these properties, particularly hydraulic conductivity, from stratified drift, till, and crystalline bedrock in eastern Connecticut have been reported in 

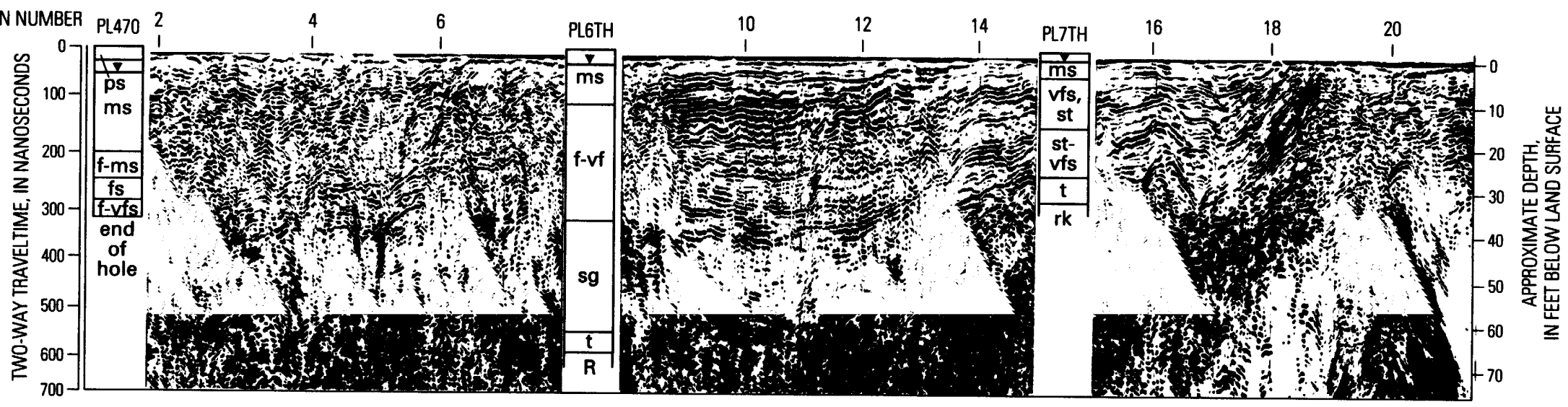

Former seepage bed

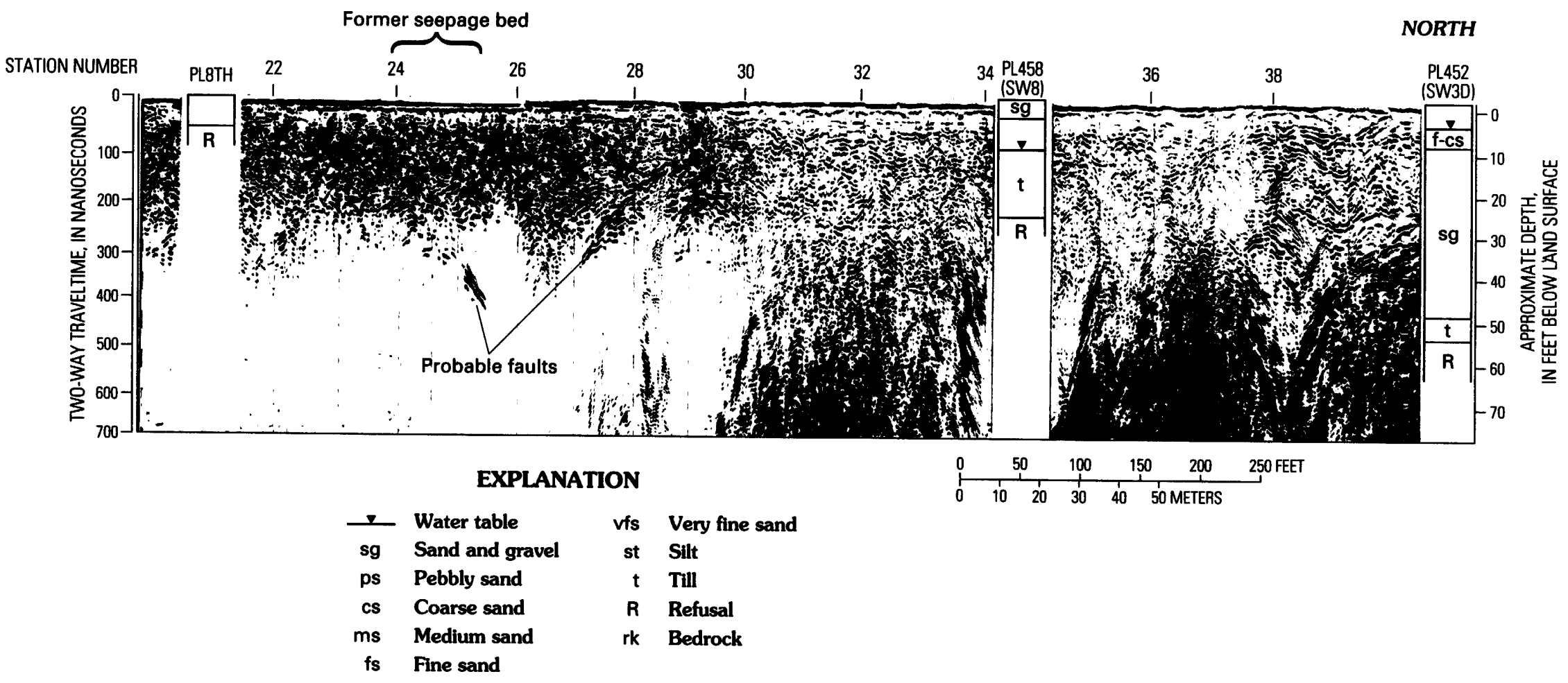

Figure 9. Ground-penetrating radar profile along line R1 and geologic interpretation. 
previous studies (Randall and others, 1966; Thomas and others, 1967; Torak, 1979; Pietras, 1981; Melvin and others, 1992a) and are summarized in table 3. Fuss and O'Neill (1979, table II-3 and appendix C) estimated the hydraulic conductivity and porosity of coarse- and fine-grained stratified drift, till, and bedrock at Gallup's Quarry to compute a ground-water flux and velocity through these materials. Their estimates also are listed in table 3.

An aquifer test was conducted at USGS well Pl 185 (fig. 5), one of the Gallup Water Service Company public supply wells located north of Gallup's Quarry, to estimate the horizontal hydraulic conductivity of the coarse-grained stratified drift (Thomas and others, 1966, p. 61). Prior analyses of test data using the Theis nonequilibrium method (Ferris and others, 1962, p. 103) resulted in an estimated coefficient of transmissibility of $100,000(\mathrm{gal} / \mathrm{d}) / \mathrm{ft}$, equal to a transmissivity of about $13,400 \mathrm{ft}^{2} / \mathrm{d}$ (Randall and others, 1966, table 21, p. 53). The horizontal hydraulic conductivity would be about $270 \mathrm{ft} / \mathrm{d}$ for the assumed saturated thickness of $50 \mathrm{ft}$. A review of the USGS file for this test indicates that alternative type-curve solutions are possible, but the data generally are difficult to analyze because of the lack of early-time measurements and the short duration (1,140 minutes) of the test.

A new estimate of transmissivity at this location was made from specific-capacity data using the method described by Theis (1963, p. 332-336). The yield of $1,500 \mathrm{gal} / \mathrm{min}$ was divided by the drawdown of $7.00 \mathrm{ft}$ measured at the end of the test in observation well Pl 185a, located $2.5 \mathrm{ft}$ from the pumped well. It was also assumed that the storage coefficient was equal to 0.1 for this analysis based on the texture of the dewatered material and duration of the test. On the basis of specific capacity, transmissivity is about 21,000 to $31,000 \mathrm{ft}^{2} / \mathrm{d}$, which corresponds to a horizontal hydraulic conductivity of about 420 to $620 \mathrm{ft} / \mathrm{d}$.

\section{Conceptualized Paths of Ground-Water Flow}

The detailed pattern of ground-water flow within and away from Gallup's Quarry at the present time (1993) has not been evaluated. General patterns of horizontal flow, however, can be inferred from water-level data collected in 1978 (Fuss and O'Neill, 1979) and from topographic and geohydrologic information. These data and information indicate that most ground water is moving in a northeastern to northwestern direction, is preferentially flowing through the coarser and more permeable stratified-drift deposits, and is primarily, if not entirely, discharging to Mill Brook and intervening tributaries and wetlands.

The horizontal flow of ground water in the glacial deposits on July 25, 1978, and December 7, 1978, has been represented by water-table contour maps (Fuss and O'Neill, 1979, pls. 3 and 4) that are reproduced here in figure 10. A third set of water-level and surface-water stage measurements was made on August 9, 1978, by Fuss and O'Neill but was not used to make a water-table map. The contours for July and December indicate that ground water in the areas of the buried seepage system and the secondary barrel disposal pit flows to the west and northwest. In the area of the primary barrel disposal pit, the water-table contours for July indicate a radial flow pattern with flow to the east, north, and west. Water-table contours for December indicate a different flow pattern in the primary barrel disposal pit area, where ground water flows to the northwest and west, but not to the north and east. The changes in the configuration of the water table in this area from July to December 1978 were attributed to the construction of a dam by beavers across Mill Brook at the railroad overpass that raised the altitude of the wetland by $1.5 \mathrm{ft}$ (Fuss and O'Neill, 1979 , p. II-13). Floods also could have a transient effect on the direction of horizontal ground-water flow in this area. Studies by the Federal Emergency Management Agency (1991) predict significant differences in the altitude of Mill Brook above and below the Conrail railroad bridge during a 100-year flood; floodwaters would extend to Gallup's Quarry.

The control for Fuss and O'Neill's "water-table" maps are the water-level measurements made in more than 30 wells and surface-water stage measurements (Fuss and O'Neill, 1979, table II-2). However, the control wells used differ with respect to the depth of the well screen below the water table and the geohydrologic unit to which the well is open (Fuss and O'Neill, 1979, appendix A). Most wells are finished in stratified drift, but wells SW4, SW13, SW15, and SW16 are screened in both stratified drift and till; wells SW6, SW8, SW9 and SW17D are screened in till, and wells SW10, SW11, and SW12 are finished in bedrock. Consequently, a number of these water-level measurements may not accurately represent the altitude of the water table and should not be used to construct water-table maps. 
※ Table 3. Hydraulic properties of stratified drift, till, and crystalline bedrock in Connecticut

[Modified from Melvin and others, 1992b, table 1; ft, feet; $\mathrm{ft} / \mathrm{d}$, feet per day; ---, no data or insufficient data]

\begin{tabular}{|c|c|c|c|c|c|}
\hline Geohydrologic unit & $\begin{array}{c}\text { Median } \\
\text { hydraulic } \\
\text { conductivity' } \\
\text { (ft/d) }\end{array}$ & $\begin{array}{l}\text { Median } \\
\text { storativity } \\
\text { (dimen- } \\
\text { sionless) }\end{array}$ & $\begin{array}{c}\text { Median } \\
\text { intergran- } \\
\text { ular porosity } \\
\text { (percent) }\end{array}$ & $\begin{array}{l}\text { Method or basis for computing median } \\
\text { hydraulic conductivity, porosity, and } \\
\text { storativity values }\end{array}$ & References \\
\hline \multicolumn{6}{|c|}{ Stratified drift } \\
\hline \multirow[t]{3}{*}{$\begin{array}{l}\text { Coarse-grained } \\
\quad \text { (sand and gravel) }\end{array}$} & 170 & & & $\begin{array}{l}\text { Aquifer tests or specific capacities adjusted for } \\
\text { partial penetration. }\end{array}$ & Randall and others (1988) \\
\hline & -- & 0.36 & -- & 25 undisturbed samples. & Do. \\
\hline & 89.4 & & 25 & Fuss and $O^{\prime}$ Neill estimate; method unknown. & Fuss and O'Neill (1979, table II-3) \\
\hline \multirow[t]{4}{*}{$\begin{array}{l}\text { Fine-grained } \\
\quad \text { (fine sand, silt, and clay) }\end{array}$} & .14 & .29 & -- & $\begin{array}{l}6 \text { undisturbed samples of lake silts, oriented } \\
\text { vertically. }\end{array}$ & Randall and others (1966) \\
\hline & .0001 & -- & -- & $\begin{array}{l}3 \text { undisturbed samples of varved clay, oriented } \\
\text { vertically. }\end{array}$ & $\begin{array}{l}\text { M.S. Klein, MRE, written commun. } \\
\text { (1981) }\end{array}$ \\
\hline & .82 & -- & -- & $\begin{array}{l}3 \text { undisturbed samples of varved clay, oriented } \\
\text { horizontally. }\end{array}$ & Do. \\
\hline & 15.5 & & 20 & $\begin{array}{l}\text { Fuss and } O^{\prime} \text { Neill estimate; method unknown. } \\
\text { Till }\end{array}$ & Fuss and O'Neill (1979, table II-3) \\
\hline $\begin{array}{l}\text { Loose surface till } \\
\quad \text { (crystalline-rock provenance) }\end{array}$ & 2.7 & .28 & -- & 10 undisturbed samples. & Randall and others (1988) \\
\hline $\begin{array}{l}\text { Compact till } \\
\text { (crystalline-rock provenance) }\end{array}$ & .06 & .04 & -- & 4 undisturbed samples, oriented vertically. & Randall and others (1966) \\
\hline \multirow[t]{2}{*}{$\begin{array}{l}\text { Till, not subdivided } \\
\text { (crystalline-rock provenance) }\end{array}$} & 6 & -- & 35 & $\begin{array}{l}\text { Slug tests of } 42 \text { wells; } 15 \text { laboratory-deter- } \\
\text { mined values of total porosity. }\end{array}$ & Torak (1979); Pietras (1981) \\
\hline & 8 & & 15 & Fuss and $O^{\prime}$ Neill estimate; method unknown. & Fuss and O'Neill (1979, table II-3) \\
\hline \multicolumn{6}{|c|}{ Crystalline bedrock } \\
\hline \multirow[t]{2}{*}{ Crystalline bedrock } & .6 & -- & 2 & $\begin{array}{l}\text { Specific capacity of } 250 \text { wells, adjusted to } \\
\text { small drawdown; laboratory-determined } \\
\text { porosity of } 5 \text { nonfractured core samples. }\end{array}$ & Randall and others (1966) \\
\hline & .2 & -- & 5 & Fuss and O'Neill estimate; method unknown. & Fuss and O'Neill (1979, table II-3) \\
\hline
\end{tabular}

${ }^{1}$ For well tests, hydraulic conductivity is equal to transmissivity divided by the saturated thickness of the geohydrologic unit that is penetrated by the well; the resulting values assume the unit is an isotropic homogeneous medium hydraulically equivalent to the real unit, which is heterogeneous. In bedrock, flow may be limited to fractures or fracture zones that intersect a small percentage of borehole length, and transmissivity and hydraulic conductivity may only be representative of the fractures and not the rock matrix.

${ }^{2}$ Specific yield for stratified drift and till. 
A.

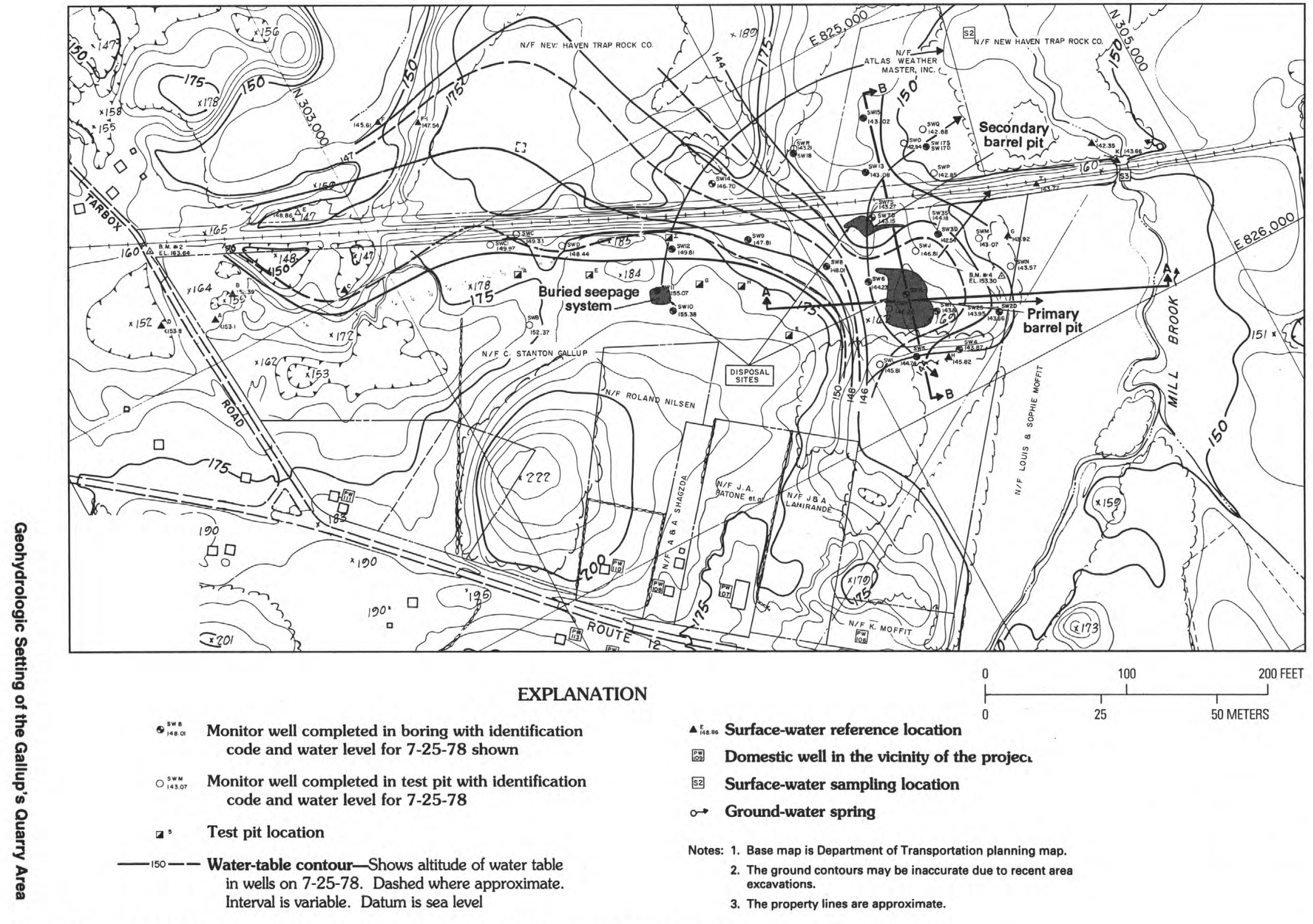

Figure 10A. Water table at Gallup's Quarry on July 25, 1978. (Modified from Fuss and O'Neill, 1979, pls. 3 and 4.) 


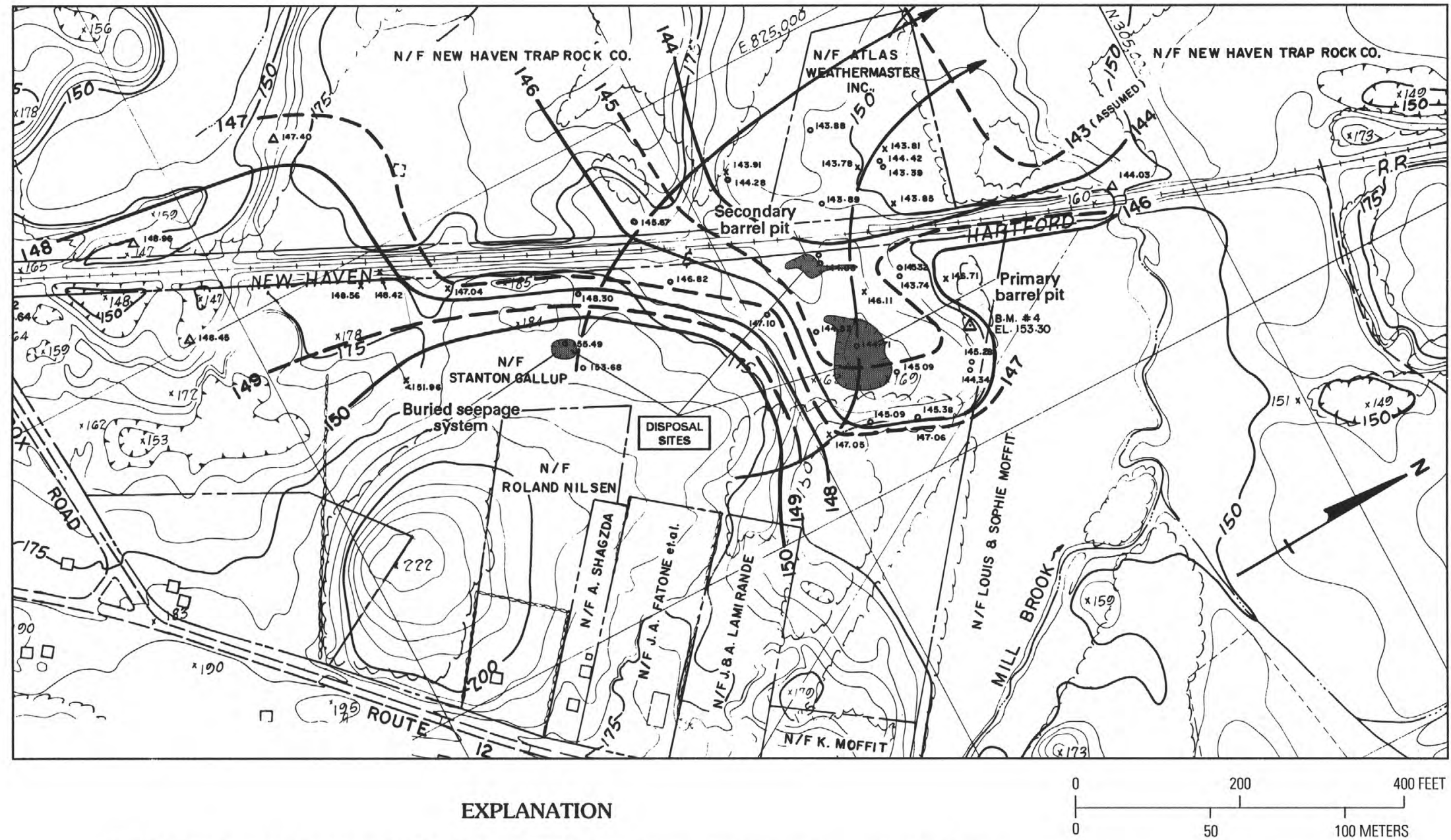

- 148. 30 Monitor well in boring with 12-7-78 water level indicated

$\times$ 147.04 Monitor well in test pit with 12-7-78 water level indicated

$\Delta$ i48.45 Surface-water reference location with 12-7-78 water level indicated

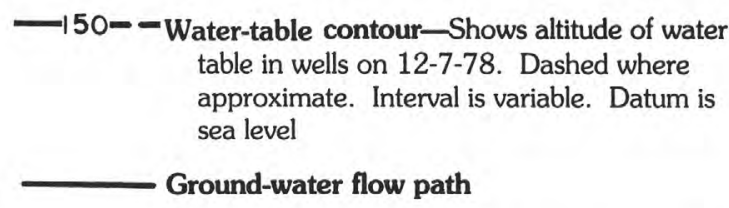
table in wells on 12-7-78. Dashed where approximate. Interval is variable. Datum is sea level

Ground-water flow path

Notes: 1. Base map is 1953 Department of Transportation planning map.

2. Property lines are approximate.

3. Contours may be changed due to excavation.

Figure 10B. Water table at Gallup's Quarry on December 7, 1978. (Modified from Fuss and O'Neill, 1979, pls. 3 and 4.) 
Selected water-level data collected by Fuss and O'Neill were analyzed for this study to determine the horizontal directions of ground-water flow in 1978 and how these directions correspond to those shown on the water-table maps. Wells finished in stratified drift and screened in the upper part of the saturated zone were selected for this analysis. Water levels in these types of wells are believed to represent the water table. The general direction of ground-water flow was determined using water-table altitudes measured in groups of three adjacent wells as described in Heath and Trainer (1968, p. 76-77). The results, shown in table 4, indicate general flow in directions ranging from N. $65^{\circ}$ E. to S. $80^{\circ} \mathrm{W}$. These directions generally correspond to those inferred from the contour maps prepared by Fuss and O'Neill (1979, pls. 3 and 4), particularly with respect to the dominant northwest direction of flow.

Records of a USGS observation well in Plainfield were examined to determine how waterlevel measurements made in July, August, and December 1978 compared to long-term observations. This observation well, identified in USGS publications as Plainfield 1 (P1 1), taps stratified drift north of Gallup's Quarry, and its location is shown in figure 5. The analysis of historical records for the period 1942-92 indicates that the water levels measured at Gallup's Quarry in 1978 were very close to the longterm median value, as shown in figure 11 . The total water-level fluctuation observed in well Pl 1 for the period of record (1942-92) is about $5 \mathrm{ft}$.

Ground water in the stratified drift, under natural conditions, ultimately discharges to Mill Brook or to tributaries and wetlands in the low areas between the disposal locations at Gallup's Quarry and Mill Brook. Two cross sections prepared by Fuss and O'Neill (1979, figs. II-1 and II-2) show interpretations of horizontal and vertical ground-water flow from the disposal areas toward these discharge points based on the water levels measured in wells in July 1978 and December 1978. The vertical direction of the groundwater flow in 1978 can be estimated at four points where there are paired shallow and deep observation wells. The water-level data for wells SW2S and SW2D and wells SW3S and SW3D show a consistently downward vertical gradient, whereas the waterlevel data for wells SW17S and SW17D show an upward vertical gradient. (See table 5.) Water levels measured in wells SW7S and SW7D indicate a downward gradient in July and August 1978 and an upward gradient in December 1978. All these wells are screened in stratified drift, with the exception of SW17D, which is screened in till.
Fuss and O'Neill (1978, p. II-10) attributed the downward hydraulic gradients near wells SW2S, SW2D, SW3S, and SW3D to a recharge mound. A downward component of ground-water flow, however, could occur under natural conditions in areas of stratified drift near the till-bedrock hill immediately south of the disposal areas. Vertical gradients at other points located near the disposal areas, such as at wells SW7S and SW7D, may also have been affected by the earlier disposal of liquid wastes. The water-level measurements at wells SW17S and SW17D indicate water was moving into the stratified drift from the underlying till at this site (and by inference from the bedrock into the till and stratified drift). A few waterlevel measurements in selected wells were made by the DEP as part of their water-quality monitoring program. Although these measurements generally are not adequate to define directions of ground-water flow, those made in wells SW17D and SW17S on October 22, 1981, also show an upward flow gradient.

The rate and velocity of ground-water flow are also controlled by the hydraulic properties of the glacial sediments. The complex association of stratified-drift and till deposits with differing hydraulic properties has already been described in a preceding section of this report. Glaciolacustrine sand and silt beneath the primary barrel pit (pl. 2 and fig. 7) would retard the downward flow of ground water and associated contaminants. These fine-grained sediments are also present east, north, and northwest of the primary and secondary barrel disposal pit areas and extend to Mill Brook. Buried coarse-grained material is inferred from geologic mapping (fig. 7 and pl. 2) to be at least discontinuously present beneath the glaciolacustrine sediments; however, there are no subsurface data in the intervening area to indicate its extent or thickness. Most ground-water flow from the disposal areas toward Mill Brook would be through the buried, more permeable coarse-grained stratified drift. Geologic mapping and logs from wells SW7S, SW7D, and SW13 (Fuss and O'Neill, 1979) indicate that the fine-grained sediments thin and pinch out west of the barrel disposal pits. (See pl. 2, geologic sections $B-B^{\prime}$ and $C-C^{\prime}$.)

Contaminants are known to have entered the fractured bedrock beneath the seepage bed (Fuss and O'Neill, 1979, p. III-7). Using water-level data from three bedrock observation wells (SW10, SW11, and SW12), Fuss and O'Neill (1979, p. II-10) inferred that ground water in the bedrock near the seepage bed was moving northwesterly under horizontal gradients of 0.02 and $0.05 \mathrm{ft} / \mathrm{ft}$. Fractured rock may not be 
Table 4. Estimated direction of horizontal ground-water flow and average horizontal gradient in the Gallup's Quarry area in 1978

[Water-table data from Fuss and O'Neill (1979, table II-2). Flow direction and gradient determined by three-point method (Heath and Trainer, 1968); N, north; S, south; E, east; W, west]

\begin{tabular}{|c|c|c|c|c|}
\hline Wells & $\begin{array}{l}\text { Water-table } \\
\text { altitude } \\
\text { (feet) }\end{array}$ & $\begin{array}{l}\text { Date of } \\
\text { measurement }\end{array}$ & $\begin{array}{c}\text { Estimated } \\
\text { direction of } \\
\text { ground-water flow }\end{array}$ & $\begin{array}{c}\text { Average } \\
\text { horizontal } \\
\text { gradient }\end{array}$ \\
\hline SW9 & 147.76 & $8-9-78$ & N. $35^{\circ} \mathrm{W}$. & 0.015 \\
\hline SW14 & 146.34 & & & \\
\hline SWR & 143.21 & & & \\
\hline SW3S & 144.91 & $8-9-78$ & N. $75^{\circ} \mathrm{W}$. & .014 \\
\hline SW7S & 143.76 & & & \\
\hline SWK & 147.13 & & & \\
\hline SW 14 & 146.70 & $7-25-78$ & N. $45^{\circ} \mathrm{W}$. & .015 \\
\hline SWJ & 146.81 & & & \\
\hline SWO & 142.94 & & & \\
\hline SW14 & 146.34 & $8-9-78$ & N. $45^{\circ} \mathrm{W}$ & .011 \\
\hline SWJ & 146.40 & & & \\
\hline SWO & 143.55 & & & \\
\hline Sw9 & 147.81 & $7-25-78$ & N. $35^{\circ}$ W. & .017 \\
\hline SW13 & 143.08 & & & \\
\hline SWR & 143.21 & & & . \\
\hline SW9 & 147.76 & $8-9-78$ & N. $40^{\circ} \mathrm{W}$. & .015 \\
\hline SW13 & 143.61 & & & \\
\hline SWR & 143.59 & & & \\
\hline SW9 & 146.82 & $12-7-78$ & N. $35^{\circ} \mathrm{W}$. & .01 \\
\hline SW13 & 143.89 & & & \\
\hline SW18 & 144.28 & & & \\
\hline SW3S & 145.32 & $12-7-78$ & S. $80^{\circ} \mathrm{W}$ & .009 \\
\hline SW7S & 144.01 & & & \\
\hline SW17S & 143.39 & & & \\
\hline SW2S & 143.95 & $7-25-78$ & N. $60^{\circ} \mathrm{E}$. & .009 \\
\hline SWK & 146.28 & & & \\
\hline SWL & 145.81 & & & \\
\hline SW2S & 144.65 & $8-9-78$ & N. $65^{\circ} \mathrm{E}$. & .01 \\
\hline SWK & 147.13 & & & \\
\hline SWL & 146.39 & & & \\
\hline SW $2 S$ & 143.78 & $7-25-78$ & N. $4^{\circ} \mathrm{W}$. & .01 \\
\hline SW3S & 144.18 & & & \\
\hline SWK & 146.28 & & & \\
\hline SW2S & 144.65 & $8-9-78$ & N. & .01 \\
\hline SW3S & 144.91 & & & \\
\hline SWK & 147.13 & & & \\
\hline
\end{tabular}




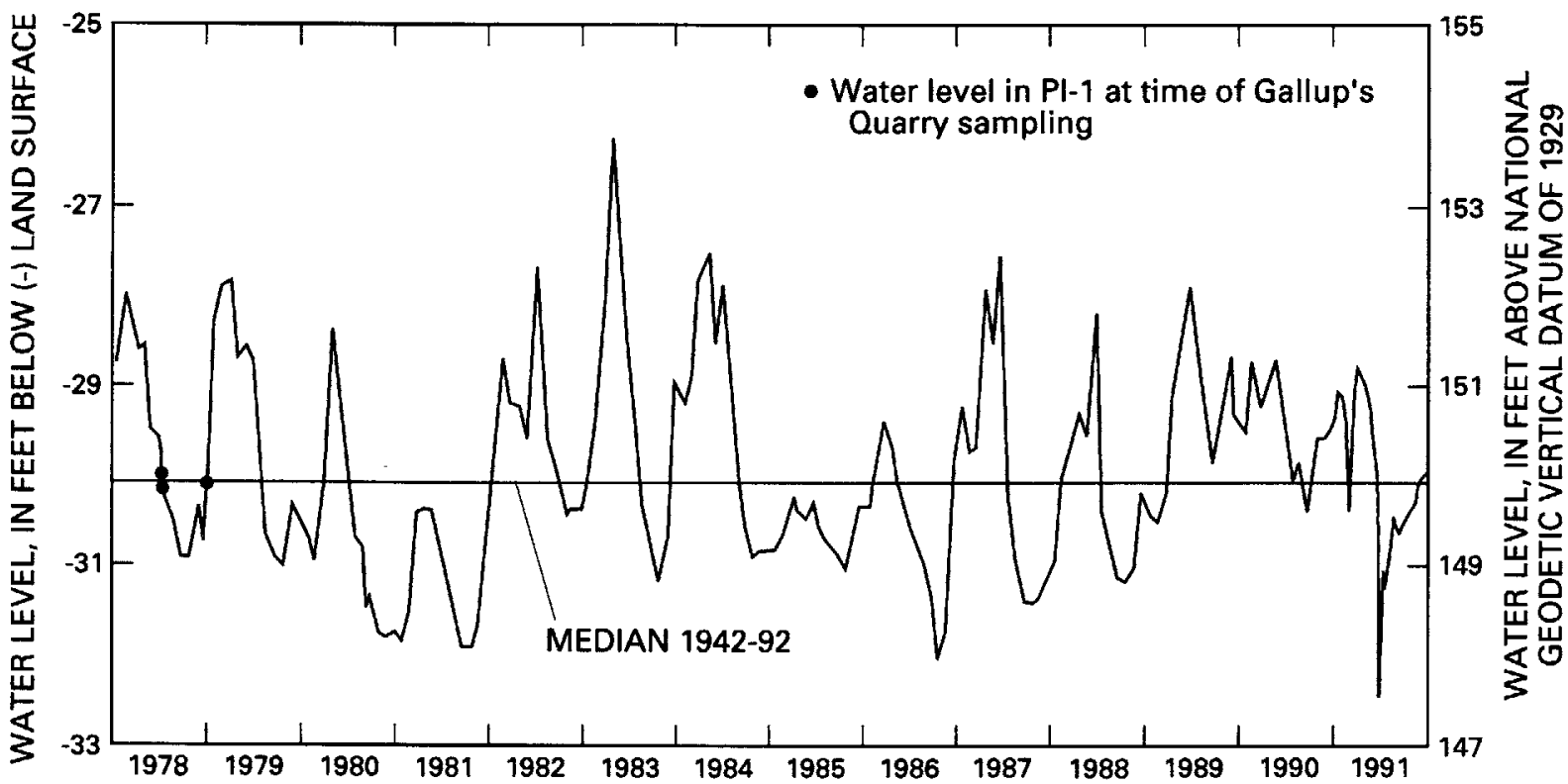

Figure 11. Water levels in U.S. Geological Survey obsenvation well PI 1, 1978-91.

hydraulically equivalent to an intergranular porous medium, in which case, these limited water-level data are not reliable measures of the direction of groundwater flow or the hydraulic gradients driving the flow within the bedrock aquifer at Gallup's Quarry. The evidence for a large fault (or fault zone) near the seepage pit has been described in previous sections of this report. This fault, if open and continuous, could serve as a conduit for the preferential northwesterly flow of ground water and dissolved contaminants.

\section{Streamflow}

Mill Brook has been identified as a principal location for the discharge of contaminated ground water from Gallup's Quarry by Fuss and O'Neill $(1979$, p. IV-1), and information on its flow is important for assessing surface-water quality. Streamflow information for Mill Brook consists of several miscellaneous discharge measurements made by the USGS in 1962,1963, and 1992; and four measurements made in September 1978 at waterquality sampling stations (Fuss and O'Neill, 1979, table III-10). Discharge measurements were also reportedly made by the DEP as part of the surfacewater quality monitoring conducted periodically during 1978-85 (Paul Marin, Department of Environmental Protection, written communs., 1980 and 1981); however, no records of DEP flow measurements were available.
A partial-record streamflow-gaging station (USGS station number 011266.42) was established in July 1992 on Mill Brook at Connecticut Route 12 (pl. 1), a short distance upstream of Gallup's Quarry to provide data on low flow. There is no known regulation of streamflow in the drainage area upstream of the quarry that would significantly affect low flows. Five discharge measurements, made from July 28 to September 14, 1992, are listed below with the flow duration, which was estimated by correlation with the daily discharge at the nearest USGS index station (Pendleton Hill Brook near Clarks Falls, Conn., station number 01118300 ) on the measurement dates. The rating curve established by these measurements is shown in figure 12 .

\begin{tabular}{lcc}
\hline $\begin{array}{c}\text { Number and date of } \\
\text { discharge } \\
\text { measurement } \\
\text { (fig. 12) }\end{array}$ & $\begin{array}{c}\text { Discharge, } \\
\text { in cubic feet } \\
\text { per second }\end{array}$ & $\begin{array}{c}\text { Estimated } \\
\text { flow duration } \\
\text { (percent) }\end{array}$ \\
\hline 1. July 28, 1992 & 1.14 & 86 \\
2. August 12, 1992 & 7.48 & 43 \\
3. August 27, 1992 & 4.57 & 77 \\
4. September 4, 1992 & 18.8 & 27 \\
5. September 14, 1992 & 6.19 & 71 \\
\hline
\end{tabular}

Selected flow characteristics of Mill Brook can be roughly estimated by regionalization techniques. Estimates of selected flow durations for Mill Brook at Route 12 are shown in table 6 . The flow-duration 
Table 5. Vertical hydraulic gradients estimated from 1978 water levels in wells in the Gallup's Quarry area

[Water-level data from Fuss and O'Neill (1979, table II-2). The length over which the gradient is calculated is equal to the difference in altitude of the midpoints of the screened intervals in the shallow and deep observation wells; well locations shown on plate 1]

\begin{tabular}{|c|c|c|c|c|}
\hline Well & $\begin{array}{l}\text { Date of } \\
\text { measurement }\end{array}$ & $\begin{array}{c}\text { Water loval } \\
\text { (altitude In feet } \\
\text { above sea level) }\end{array}$ & $\begin{array}{l}\text { Difference in } \\
\text { water levels } \\
\text { (feet) }\end{array}$ & $\begin{array}{l}\text { Estimated vertlcal } \\
\text { hydraulic gradient } \\
\text { and direction }\end{array}$ \\
\hline $\begin{array}{l}\text { SW2S, } \\
\text { SW2D }\end{array}$ & $7-25-78$ & $\begin{array}{l}143.95 \\
143.66\end{array}$ & 0.29 & 0.011 , down \\
\hline $\begin{array}{l}\text { SW2S, } \\
\text { SW2D }\end{array}$ & $8-9-78$ & $\begin{array}{l}144.65 \\
144.38\end{array}$ & .27 & .011 , down \\
\hline $\begin{array}{l}\text { SW2S, } \\
\text { SW2D }\end{array}$ & $12-7-78$ & $\begin{array}{l}145.28 \\
144.84\end{array}$ & .44 & .017 , down \\
\hline $\begin{array}{l}\text { SW3S, } \\
\text { SW3D }\end{array}$ & $7-25-78$ & $\begin{array}{l}144.18 \\
142.54\end{array}$ & 1.64 & .075 , down \\
\hline $\begin{array}{l}\text { SW3S, } \\
\text { SW3D }\end{array}$ & $8-9-78$ & $\begin{array}{l}144.91 \\
143.25\end{array}$ & 1.66 & .076 , down \\
\hline $\begin{array}{l}\text { SW3S, } \\
\text { SW3D }\end{array}$ & $12-7-78$ & $\begin{array}{l}145.32 \\
143.74\end{array}$ & 1.58 & .072 , down \\
\hline $\begin{array}{l}\text { SW7S, } \\
\text { SW7D }\end{array}$ & $7-25-78$ & $\begin{array}{l}143.27 \\
143.15\end{array}$ & .12 & .013 , down \\
\hline $\begin{array}{l}\text { SW7S, } \\
\text { SW7D }\end{array}$ & $8-9-78$ & $\begin{array}{l}143.76 \\
143.75\end{array}$ & .01 & .001 , down \\
\hline $\begin{array}{l}\text { SW7S, } \\
\text { SW7D }\end{array}$ & $12-7-78$ & $\begin{array}{l}144.01 \\
144.08\end{array}$ & .07 & .007, up \\
\hline $\begin{array}{l}\text { SW17S, } \\
\text { SW17D }\end{array}$ & $12-7-78$ & $\begin{array}{l}143.39 \\
144.42\end{array}$ & 1.03 & .048 , up \\
\hline
\end{tabular}

estimates are based on the regional flow-duration curves developed by Thomas (1966). The 7-day, 10 -year low flow at this location can also be estimated from a regional formula developed by regression analysis that is described in Cervione and others (1982). The 7-day, 10-year low-flow estimate is $1.1 \mathrm{ft}^{3} / \mathrm{s}$. It should be noted that both the duration and frequency estimates apply only to unregulated streams and are based on the reference period October 1, 1930, through September 30,1960, for duration and the reference period April 1, 1941, through

March 31, 1971, for the 7-day, 10-year low flow.

\section{WATER QUALITY AND RESIDUAL SEDIMENT CONTAMINATION}

Gallup's Quarry is a complex waste-disposal area where many types of organic and inorganic chemical wastes were disposed of, in unknown quantities and at indeterminate times, into glacial sediments and fractured bedrock; approximately 15 years have elapsed since discovery of this wastedisposal area and its partial remediation. The organic compounds classified as DNAPL's, are of particular concern because they are difficult to attenuate by 


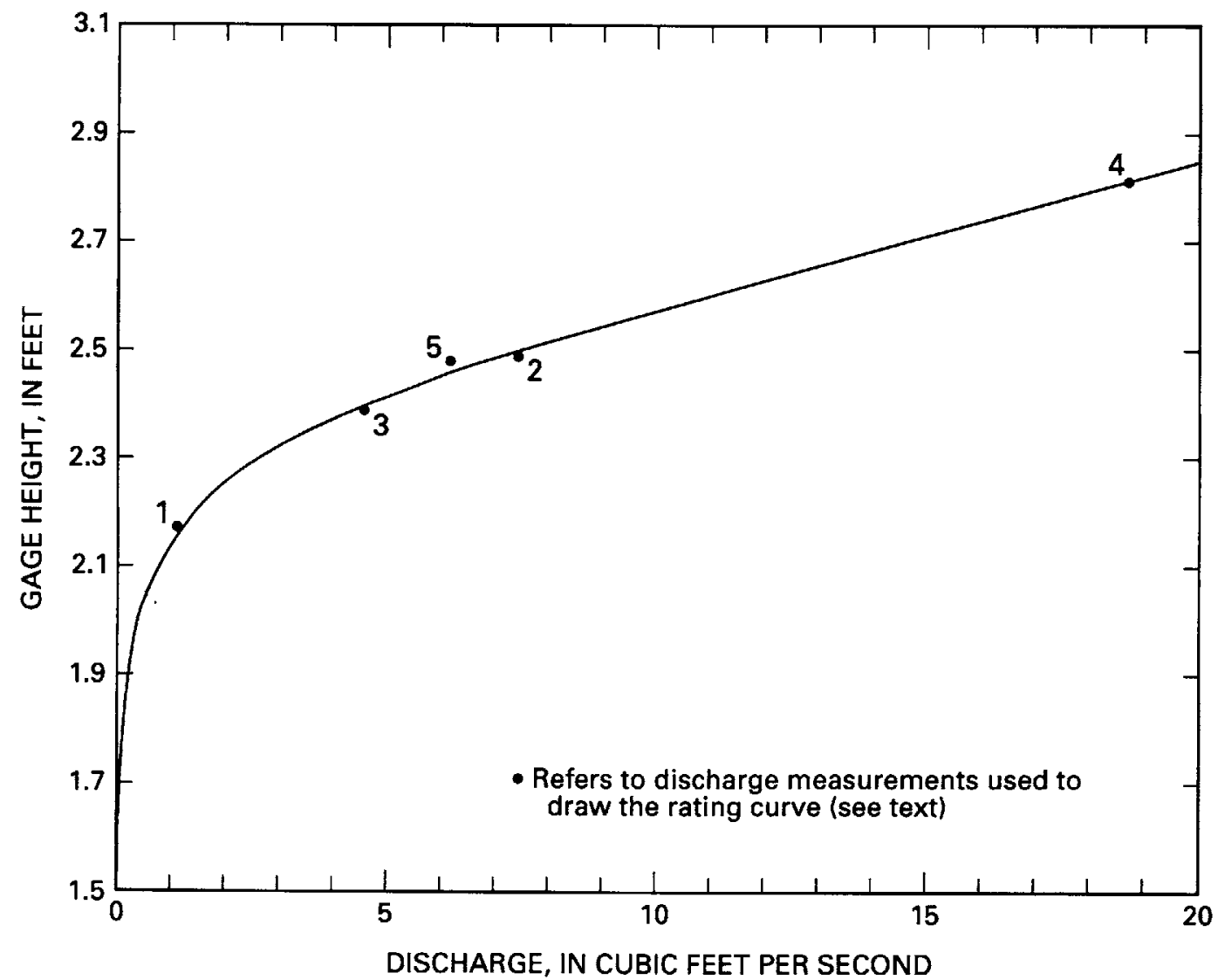

Figure 12. Rating curve for partial-record streamflow-gaging station on Mill Brook at Route 12, Plainfield, Conn. (USGS station number 011266.42).

Table 6. Selected flow durations estimated for Mill Brook at Connecticut Route 12 (USGS station number 011266.42)

[Flow durations estimated from regional flow-duration curves developed by Thomas (1966). Daily flows calculated using a drainage area of 9.11 square miles]

\begin{tabular}{cc}
\hline $\begin{array}{c}\text { Flow duration } \\
\text { (percent) }\end{array}$ & $\begin{array}{c}\text { Dally flow, } \\
\text { in cubic feet per second }\end{array}$ \\
\hline 99 & 0.64 \\
95 & 1.1 \\
90 & 1.6 \\
80 & 3.0 \\
70 & 5.0 \\
50 & 10 \\
30 & 18 \\
10 & 36 \\
\hline
\end{tabular}

natural processes. The transport and fate of these DNAPL's in the subsurface commonly differs from that of other organic contaminants (Schwille, 1988).
DNAPL's may sink in ground water, move upgradient, be trapped in capillary pores or in small fractures, and (or) be present as a separate nonaqueous-phase liquid within the mass of ground water at high concentrations. The movement of these compounds as a separate phase is difficult to predict, and they may accumulate and persist for long periods of time. Since 1978, when the waste-disposal area was discovered, considerable degradation, sorption, and transport have probably occurred, changing the concentrations, distribution, and composition of contaminants. An estimated 450 in. of recharge during the 15 years after cessation of waste disposal would have depressed the contaminant plumes and diluted contaminant concentrations.

The available analytical data and field observations on the quality of ground water and surface water and contaminants in recent streambed sediments and in glacial sediments in the Gallup's Quarry area were reviewed for this study. In addition, these data have recently been summarized in a report prepared for the USEPA (Metcalf and Eddy, 1992). The historic data indicate that the quality of water and 
sediments has been affected by waste disposal at Gallup's Quarry. Analytical results from Fuss and O'Neill (1979) and subsequent monitoring have detected synthetic organic compounds and inorganic constituents whose concentrations exceed established National Drinking Water-Quality Standards (U.S. Environmental Protection Agency, 1992), as well as other water-quality criteria (U.S. Environmental Protection Agency, 1986) and the background levels reported by Randall and others (1966). It is also possible that the synthetic organic compounds and elevated concentrations of other constituents in water and sediments in Mill Brook resulted partly, or wholly, from activities other than waste disposal at Gallup's Quarry.

Systematic monitoring was terminated in the early 1980 's, and therefore, the extent and magnitude of contamination of water and sediments that presently (1993) exists in the Gallup's Quarry area is unknown. A reconnaissance electromagnetic survey was conducted in October 1992 by the USGS to determine if there were any anomalous measurements of terrain conductivity that may be indicative of contaminated ground water or residual contamination of the glacial sediments. The locations of the electromagnetic survey lines are shown on plate 1 , and the terrainconductivity measurements and possible interpretations are discussed in this section of the report.

The major classes of chemical constituents detected in water and sediments at Gallup's Quarry include trace inorganic constituents (metals) and synthetic organic compounds (including solvents and dyes). Several synthetic organic compounds that have been detected at high concentrations in ground-water samples from Gallup's Quarry can be characterized as dense nonaqueous phase liquids (DNAPL's). Other inorganic and organic substances could have been present in the water and sediment samples but were not analyzed for, or were present in concentrations that were below the detection limit of the analytical method. The transport and fate of these diverse constituents are generally not well understood, particularly the DNAPL's, but are undoubtedly complex because of interactions between the constituents themselves, interactions between the constituents and matrix minerals of the subsurface geohydrologic units, degradation processes, and the heterogeneous geohydrologic setting. Any assessment of the fate, transport, areal distribution, and persistence of contaminants in water or sediments in this area is further complicated by the sparse information on volumes and chemical composition of wastes disposed of at various times at each of the three known disposal areas.

\section{Quality of Ground Water}

The ground-water quality at and near Gallup's Quarry was initially investigated by Fuss and O'Neill (1979) as part of the hydrogeologic study authorized by the DEP in 1978. During Fuss and O'Neill's investigation, 22 borings and 18 test pits were completed on the Gallup property and on adjacent land west of the Conrail railroad line. Monitoring wells were installed in all 22 borings and in 13 of the 18 test pits as shown on plate 1 . Four of these monitoring wells were screened in both stratified drift and till, 4 were screened in till, 3 were screened in bedrock, and the remaining 24 were screened in stratified drift.

A ground-water sampling program was initiated in 1978, and samples were collected in July, October, and December from the 35 monitoring wells and from 9 private wells located near Connecticut Route 12, between Mill Brook and Tarbox Road. The July samples were used to develop a baseline profile of water quality at each well. Samples were collected from the monitoring wells using suction pumps and bailers, and each sample was analyzed in the field for specific conductance, $\mathrm{pH}$, and in-situ temperature. The procedure used for sampling the domestic wells is unknown. In addition, each sample was analyzed by various laboratory methods for inorganic and organic constituents. Each sampling event was modified according to the results of the prior sampling and analyses. The modifications included sampling only selected wells and analyzing the samples for only a selected number of constituents. All the analytical data from the 1978 sampling are presented by Fuss and O'Neill (1979, tables III-2 to III-9), and a summary of analytical data for samples from wells that had the highest concentrations of chemical constituents, prepared by Metcalf and Eddy (1992), is shown in table 7. Because of the use of bailers and suction pumps to collect samples, concentrations of volatile organic compounds in ground water may have been greater than indicated by these analyses.

The analyses reported by Fuss and O'Neill (1979) indicate that the principal ground-water contaminants in the Gallup's Quarry area in the latter part of 1978 were trace metals, including boron, 
Table 7. Summary of analyses of water samples collected from selected wells at Gallup's Quarry in 1978

[From Metcalf and Eddy, 1992, table 3-3. $\mu \mathrm{g} / \mathrm{L}$, micrograms per liter; $\mathrm{mg} / \mathrm{L}$, milligrams per liter; $\mu$ mhos/cm, micromhos per centimeter; ND, not detected; NA, not analyzed]

\begin{tabular}{|c|c|c|c|c|c|c|c|c|c|}
\hline \multirow{2}{*}{$\begin{array}{c}\text { Constituent } \\
\text { (unit of measurement) }\end{array}$} & \multirow[b]{2}{*}{ Date } & \multicolumn{3}{|c|}{ Well SW7S } & \multicolumn{3}{|c|}{ Well SW7D } & \multicolumn{2}{|c|}{ Well SW11 } \\
\hline & & $7 / 78$ & $10 / 78$ & $12 / 78$ & $7 / 78$ & $10 / 78$ & $12 / 78$ & $7 / 78$ & $10 / 78$ \\
\hline Methyl isobutyl ketone $(\mu \mathrm{g} / \mathrm{L})$ & & 75,000 & 10,000 & 25,000 & 30,000 & 20,000 & 10,000 & ND & ND \\
\hline 2-Butanone (MEK) $(\mu \mathrm{g} / \mathrm{L})$ & & ND & 25,000 & 60,000 & ND & ND & 40,000 & ND & 4,000 \\
\hline Tetrachloroethene $(\mu \mathrm{g} / \mathrm{L})$ & & 5 & ND & ND & 4 & ND & ND & ND & ND \\
\hline Trichloroethane $(\mu \mathrm{g} / \mathrm{L})$ & & 150 & ND & ND & ND & 25 & ND & ND & ND \\
\hline Trichloroethene $(\mu \mathrm{g} / \mathrm{L})$ & & ND & ND & ND & 75 & 25 & ND & ND & ND \\
\hline Methylene chloride $(\mu \mathrm{g} / \mathrm{L})$ & & ND & 2,000 & ND & ND & 5,000 & ND & ND & 15,000 \\
\hline Acetone $(\mu \mathrm{g} / \mathrm{L})$ & & ND & ND & 15,000 & ND & 2,000 & 15,000 & ND & 2,000 \\
\hline Toluene $(\mu \mathrm{g} / \mathrm{L})$ & & 10,000 & 2,000 & ND & 5,000 & 3,000 & ND & ND & ND \\
\hline Xylenes $(\mu \mathrm{g} / \mathrm{L})$ & & 1,000 & 4,000 & ND & ND & ND & ND & ND & ND \\
\hline Chloride (mg/L) & & 3,150 & NA & NA & 3,080 & NA & NA & 21.3 & NA \\
\hline Specific conductance $(\mu \mathrm{mhos} / \mathrm{cm})$ & & 26,000 & NA & NA & 10,000 & NA & NA & 3,850 & NA \\
\hline Copper (mg/L) & & 1,185 & 625 & 1,970 & 485 & 75 & 800 & 5.87 & 12.3 \\
\hline Aluminum $(\mathrm{mg} / \mathrm{L})$ & & 1,440 & NA & NA & 272 & NA & NA & ND & NA \\
\hline Nickel $(\mathrm{mg} / \mathrm{L})$ & & 105 & 0.37 & 151 & 91.7 & 11.7 & 50.4 & ND & 1.23 \\
\hline Iron $(\mathrm{mg} / \mathrm{L})$ & & 775 & 420 & 220 & ND & 28.3 & 160 & ND & 150 \\
\hline Zinc (mg/L) & & 270 & 154 & 500 & ND & 1.23 & 140 & ND & 6.05 \\
\hline
\end{tabular}


Table 7. Summary of analyses of water samples collected from selected wells at Gallup's Quarry in 1978-Continued

\begin{tabular}{|c|c|c|c|c|c|c|c|c|c|c|}
\hline \multirow[b]{2}{*}{$\begin{array}{c}\text { Constituent } \\
\text { (unit of measurement) }\end{array}$} & \multirow[b]{2}{*}{ Date } & \multicolumn{3}{|c|}{ Well SW13 } & \multicolumn{3}{|c|}{ Well SW17S } & \multicolumn{3}{|c|}{ Well SW17D } \\
\hline & & $7 / 78$ & $10 / 78$ & $12 / 78$ & $7 / 78$ & $10 / 78$ & $12 / 78$ & $7 / 78$ & $10 / 78$ & $12 / 78$ \\
\hline Methyl isobutyl ketone $(\mu \mathrm{g} / \mathrm{L})$ & & ND & ND & 15,000 & NA & 15,000 & ND & NA & ND & ND \\
\hline 2-Butanone (MEK) $(\mu \mathrm{g} / \mathrm{L})$ & & ND & ND & ND & NA & ND & 5,000 & NA & ND & ND \\
\hline Tetrachloroethene $(\mu \mathrm{g} / \mathrm{L})$ & & 5 & 2 & ND & NA & ND & ND & NA & ND & ND \\
\hline Trichloroethane $(\mu \mathrm{g} / \mathrm{L})$ & & 100 & 50 & ND & NA & ND & ND & NA & ND & ND \\
\hline Trichloroethene $(\mu \mathrm{g} / \mathrm{L})$ & & 100 & 15 & ND & NA & ND & ND & NA & ND & ND \\
\hline Methylene chloride $(\mu \mathrm{g} / \mathrm{L})$ & & ND & 25,000 & ND & NA & ND & ND & NA & 5,000 & ND \\
\hline Acetone $(\mu \mathrm{g} / \mathrm{L})$ & & ND & ND & 2,000 & NA & ND & ND & NA & ND & ND \\
\hline Toluene $(\mu \mathrm{g} / \mathrm{L})$ & & 12,000 & ND & ND & NA & ND & ND & NA & ND & ND \\
\hline Xylenes $(\mu \mathrm{g} / \mathrm{L})$ & & 27,000 & ND & ND & NA & ND & ND & NA & ND & ND \\
\hline Chloride (mg/L) & & 360 & NA & NA & 295 & NA & NA & 568 & NA & NA \\
\hline Specific conductance $(\mu \mathrm{mhos} / \mathrm{cm})$ & & 1,050 & NA & NA & NA & NA & NA & NA & NA & NA \\
\hline Copper $(\mathrm{mg} / \mathrm{L})$ & & ND & 88 & 96 & NA & .13 & .33 & NA & .59 & 0.41 \\
\hline Aluminum $(\mathrm{mg} / \mathrm{L})$ & & ND & NA & NA & NA & NA & NA & NA & NA & NA \\
\hline Nickel (mg/L) & & ND & 6.84 & 59 & NA & .53 & .096 & NA & 2.35 & $<.005$ \\
\hline Iron $(\mathrm{mg} / \mathrm{L})$ & & ND & 8.86 & 17.9 & NA & .11 & 6.06 & NA & .86 & 2.4 \\
\hline Zinc (mg/L) & & ND & 20 & 22.2 & NA & 2.1 & .42 & $\mathrm{NA}$ & 1.25 & .098 \\
\hline
\end{tabular}


cadmium, copper, iron, lead, manganese, nickel, and zinc, and a variety of synthetic organic solvents, including acetates, benzene, ethanol, isopropanol, methylene chloride, 2-butanone (MEK), methyl isobutyl ketone (MIBK), methanol, toluene, and xylene. In addition, basic constituents and properties, such as chloride concentration, chemical oxygen demand (COD), $\mathrm{pH}$, and specific conductance of water samples from several wells differed considerably from values typical of ambient ground-water quality in this area. The analyses of water from the nine private wells along Route 12 detected no organic contaminants, and concentrations of copper, detected in all samples, were considered to be within the range of general background quality or the result of a reaction between ground water and copper piping (Fuss and O'Neill, 1979, p. III-26 to III-27).

The DEP continued to monitor the ground-water quality by collecting and analyzing samples intermittently from October 1979 through October 1981. Data from the files of the DEP Water Management Bureau indicate that this monitoring consisted of obtaining samples from various wells at one or more times during this period. Eleven of the monitoring wells (SW2S, SW5, SW7S, SW7D, SW11, SW12, SW13, SW15, SW17S, SW17D, and SW18) were sampled at least three times. The specific conductance and COD of the ground-water samples were determined, and the samples were analyzed for concentrations of chloride and selected metals and hydrocarbons. Many of these samples contained detectable concentrations of metals (cadmium, chromium, copper, nickel, and zinc) and synthetic organic compounds (butane, butyl alcohol, s-butyl alcohol, methylene chloride, tetrachloroethane, tetrachloroethylene, 1,1,1 trichloroethane, and trichloroethylene). Concentrations of halogenated solvents, categorized as DNAPL's, were several thousand micrograms per liter in some samples (Metcalf and Eddy, 1992, table 3-4 and appendix B). In November 1980, the DEP also installed and sampled one new well, which they identified as "SWX" (Paul Marin, Department of Environmental Protection, written commun., 1980). This well is believed to have been located in one of the swampy areas between Gallup's Quarry and Mill Brook, but no location map was found in the DEP files nor was the well found during field work for this study. Several synthetic organic compounds were detected in samples collected from this well on November 19, 1980 (methylene chloride, $50 \mu \mathrm{g} / \mathrm{L}$; toluene, $35 \mu \mathrm{g} / \mathrm{L}$; 1,1,1-trichloroethane, $640 \mu \mathrm{g} / \mathrm{L}$; and trichloroethylene, $100 \mu \mathrm{g} / \mathrm{L}$ ). If the assumed location is correct, these data show migration of contaminants beyond the limits of the network of monitoring wells installed in 1978.

Additional sampling and analyses of ground water from Gallup's Quarry was conducted by NUS Corporation in December 1986. Two wells, SW17D and SW18, were sampled, and six synthetic hydrocarbons were detected in the sample from well SW17D (Metcalf and Eddy, 1992, p. 2-10). The concentrations of toluene (greater than $548 \mu \mathrm{g} / \mathrm{L}$ ) and $\mathrm{m}$-xylene $(367 \mu \mathrm{g} / \mathrm{L})$ were the highest of any of the detected compounds. Water samples from private domestic wells were collected and analyzed as part of the DEP monitoring and again by the USEPA in 1989 (Alex Sherrin, U.S. Environmental Protection Agency, written commun., 1989). Trace contamination was detected in some samples, although concentrations did not exceed the USEPA Maximum Contaminant Levels for drinking water. No correlation was made between the presence of low-level contamination and waste disposal at Gallup's Quarry.

\section{Quality of Surface Water and Stream-Bottom Sediment}

Surface-water and sediment-quality monitoring sites were established by Fuss and O'Neill (1979) in the Mill Brook Basin. Selected sites located between Route 12 and Fry Brook are listed below.

\begin{tabular}{cl}
\hline $\begin{array}{c}\text { Sample } \\
\text { point }\end{array}$ & \multicolumn{1}{c}{ (See plate 1 for location of sites S1-S5) } \\
\hline S1 & Mill Brook at Route 12 \\
S2 & $\begin{array}{c}\text { Wetland impoundment 350 feet northwest of } \\
\text { SW15 }\end{array}$ \\
S3 & Mill Brook at railroad bridge \\
S4 & Mill Brook above confluence with Fry Brook \\
S5 & Fry Brook above confluence with Mill Brook \\
\hline
\end{tabular}

Water samples from some or all of these locations were collected and analyzed by Fuss and O'Neill in September, October, and November 1978 and by the DEP on seven different dates between October 1979 and November 1983. Water-quality data from these sites contained in the Fuss and O'Neill report (Fuss and O'Neill, 1979) and DEP files were reviewed for this study. It was determined that the 
water quality of Fry Brook has been historically poor; this fact together with the effluent discharges from the Plainfield wastewater-treatment facility, likely mask downstream changes in the water quality of Mill Brook caused by other contaminant sources.

Consequently, water-quality data at points on Fry Brook or on Mill Brook below its confluence with Fry Brook (S5, S6, S7) are not discussed in this report.

Available data from sites S1, S2, S3, and S4 indicate some degradation of the quality of surface water and stream-bottom sediments in Mill Brook has resulted from human activities. Fuss and O'Neill (1979) concluded that detections of methylene chloride $(20 \mu \mathrm{g} / \mathrm{L}), 1,1,1$-trichloroethane $(70 \mu \mathrm{g} / \mathrm{L})$, and trichloroethylene $(20 \mu \mathrm{g} / \mathrm{L})$ at $\mathrm{S} 4$, and their absence upstream at sites $\mathrm{S} 1$ and $\mathrm{S} 3$, resulted from the discharge of contaminated ground water from Gallup's Quarry. Low concentrations of toluene, 1,1,1-trichloroethane, and trichloroethylene were also detected at the S4 site in January 1980 but not upstream (Department of Environmental Protection, written commun., 1980). The DEP staff in January 1986 stated that leachate from Gallup's Quarry was still breaking out in Mill Brook approximately $500 \mathrm{ft}$ below the Conrail railroad bridge (Joseph Nestico, Department of Environmental Protection, written commun., 1986). This conclusion was based on visual observation of the streambed and biological evidence.

The historic water-quality and sediment-quality data do not provide conclusive evidence of the source(s) of the observed degradation, although the discharge of degraded ground water from Gallup's Quarry into Mill Brook is to be expected based on the current understanding of the local geohydrology.

Synthetic organic compounds have also been periodically detected in samples of water and streambottom sediments collected at the upstream locations (sites S1 and S3) on Mill Brook. However, these sites, in particular site $S 1$, are located upstream from the reach of Mill Brook that has been reportedly affected by the discharge of contaminated ground water from Gallup's Quarry. Analytical data on concentrations of metals do not appear to resolve the question of provenance because concentrations are commonly similar at sites $\mathrm{S} 1, \mathrm{S3}$, and $\mathrm{S} 4$.

The USGS conducted a reconnaissance survey of the specific conductance and water temperature of Mill Brook on September 21, 1992. The purpose of the survey was to see whether, during a period of low flow, changes in specific conductance of the stream could be related to specific conductance of ground water discharging to the stream. Measurements were made at nine sites on Mill Brook between the gaging station on Route 12 and a point $100 \mathrm{ft}$ downstream from Fry Brook, in a swampy area south of Mill Brook, and in Fry Brook near its mouth. The flow of Mill Brook at Route 12 was about $2.3 \mathrm{ft}^{3} / \mathrm{s}$ at the time this survey was made. Locations where measurements were made are shown on plate 1 , and the specificconductance values are listed below.

\begin{tabular}{lc}
\hline $\begin{array}{c}\text { Site } \\
\text { identification }\end{array}$ & $\begin{array}{c}\text { Specific conductance, in } \\
\text { microsiemens per centimeter } \\
\text { at 25 degrees Celsius }\end{array}$ \\
\hline Q1 (Mill Brook) & 187 \\
Q2 (Fry Brook) & 231 \\
Q3 (Mill Brook) & 110 \\
Q4 (Mill Brook) & 109 \\
Q5 (Mill Brook) & 109 \\
& \\
Q6 (Swampy area) & 38 \\
Q7 (Mill Brook) & 108 \\
Q8 (Mill Brook) & 106 \\
Q9 (Mill Brook) & 102 \\
Q10 (Mill Brook) & 102 \\
& \\
Q11 (Mill Brook) & 100 \\
\hline
\end{tabular}

A small downstream increase of 4 to $8 \mu \mathrm{S} / \mathrm{cm}$ was measured in Mill Brook, starting at site Q9, located about $425 \mathrm{ft}$ below the Conrail railroad bridge and ending just upstream from Fry Brook at site Q3. The observed differences, however, are so small that they are not considered indicative of changes in water quality caused by discharge of ground water that is more conductive due to dissolved contaminants. However, a notable increase in specific conductance was measured at site $Q 1$, which is downstream from the confluence with Fry Brook - a result of mixing with the comparatively high specific conductance water in Fry Brook. The relatively low specific conductance of the water from the swampy area (site Q6) indicates that it is locally derived from precipitation and (or) discharge of ground water with low specific conductance. 


\section{Glacial Sediments}

Samples of glacial sediment collected from a pit excavated on the Gallup property near the seepage bed during the 1978 remediation effort were analyzed for several metals, free acid, and $\mathrm{pH}$ (Fuss and O'Neill, 1979 , p. III-6 to III-7). The concentrations are in milligrams per liter, indicating that the analyses may have been done on interstitial pore fluid. The sampling protocols are unknown, but the analytical results as summarized by Fuss and O'Neill are shown below.

\begin{tabular}{ll}
\hline \multicolumn{1}{c}{ Constituent } & \multicolumn{1}{c}{ Range of concentration } \\
\hline Iron as $\mathrm{Fe}$ & 25 to 6,100 milligrams per liter \\
Manganese as $\mathrm{Mn}$ & 2.7 to 98 milligrams per liter \\
Copper as $\mathrm{Cu}$ & 1.5 to 7.9 milligrams per liter \\
Zinc as $\mathrm{Zn}$ & 0.2 to 9.7 milligrams per liter \\
Nickel as Ni & 0.2 to 5.8 milligrams per liter \\
& \\
Chromium as $\mathrm{Cr}$ & 0.3 to 4.2 milligrams per liter \\
Cadmium as Cd & 0.1 to 4.0 milligrams per liter \\
Cobalt as Co & 0.24 to 0.33 milligrams per liter \\
Free acid as $\mathrm{H}_{2} \mathrm{SO}_{4}$ & 0 to 1.3 percent \\
Equivalent acid & 1.5 to 3.0 percent \\
as $\mathrm{H}_{2} \mathrm{SO}_{4}$ & \\
\hline
\end{tabular}

Samples of glacial sediment were also collected and analyzed at the locations of wells SW7D and SW1, located near the secondary and primary barrel disposal pits, respectively. According to Fuss and O'Neill (1979, p. III-20), these analyses "all indicate significant remaining interstitial contamination." In addition, visual observations of soil staining were made during the initial investigations of both the primary and secondary barrel disposal pit areas.

Residual contamination of glacial sediments at Gallup's Quarry was detected during this study. USGS personnel mapping the geology in the fall of 1992 observed extensively stained sand at the former secondary barrel disposal pit area. The stained sediment was adjacent to the pit that was excavated as part of the DEP-managed remediation work in 1978. Samples were subsequently collected and analyzed by USEPA. The analytical results indicate that the compound causing the staining is composed of copper and cyanide (Michael Jasinski, U.S. Environmental Protection Agency, oral commun., 1993).

A reconnaissance electromagnetic survey was conducted by the USGS to identify any anomalies in terrain conductivity downgradient of Gallup's Quarry that could be indicative of a residual plume or residual contamination of glacial sediments. Data were collected in both the horizontal-dipole mode with 20-m spacing (fig. 13A) and vertical-dipole mode with 20-m spacing (fig. 13B) using a Geonics EM-34 instrument. Data from line E1, which is near the railroad track, were not used to construct the contours in figure 13 because the values of conductivity measured along this line are believed to have been affected by the railroad line and the buried debris adjacent to it. Anomalous values of terrain conductivity, greater than $60 \mathrm{mS} / \mathrm{m}$ (millisiemens per meter) in the horizontal-dipole mode and greater than $50 \mathrm{mS} / \mathrm{m}$ in the vertical-dipole mode, form a series of distinct highs that have a northwest trend away from the Gallup's Quarry waste-disposal areas. This direction is coincident with the principal direction of horizontal ground-water flow determined from the 1978 water levels. The cause of the relatively high terrain conductivity is unknown. It may result from the presence of highly conductive ground water representing the persistence of contamination 15 years after any waste-disposal activities. Other possibilities include sorption or precipitation of conductive metals on the matrix of the glacial sediments or a change in the depth to bedrock or in lithology.

It is possible that there are contaminant source areas at Gallup's Quarry other than the three known waste-disposal sites. In October 1981, the DEP staff surveyed an area 200 to about $400 \mathrm{ft}$ southeast of monitoring wells SWB, SWC, SWC1, and SWD (pl. 1) where a partly buried drum and 3-in. diameter hose were found (Paul Marin, Department of Environmental Protection, written commun., 1982). Asphalt and asphalt-coated pipe were discovered during the field inspection, and two sediment samples were collected. Analysis of these two samples indicated the presence of acetone at concentrations of $2,300 \mathrm{ppb}$ (parts per billion) and $830 \mathrm{ppb}$, methyl ethyl ketone (MEK) at $380 \mathrm{ppb}$ and a "trace;" and 1,1,1-trichloroethane at concentrations of $1,500 \mathrm{ppb}$ and $7 \mathrm{ppb}$. On November 11, 1981, the DEP resampled these materials, collecting two samples at the same locations as the October samples and at two new but unidentified locations considered to represent background conditions. The analysis of the replicate samples indicated only trace quantities of acetone and MEK. The analysis of the assumed background samples indicated traces of acetone, MEK, methyl alcohol, and pentane.

After reviewing the history of the area, the DEP staff attributed the sediment contamination to the 

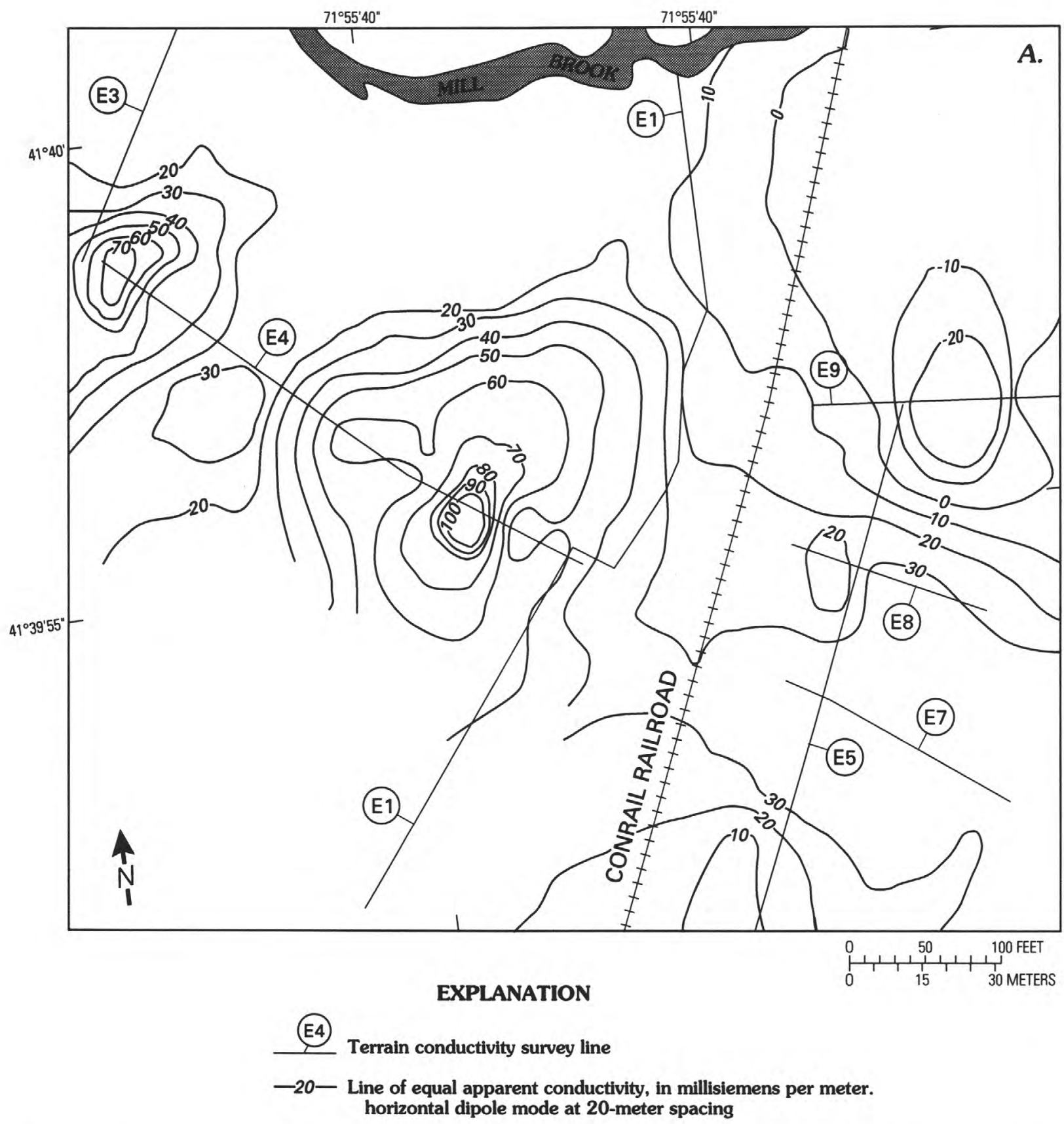

Figure 13A. Lines of equal apparent terrain conductivity in the Gallup's Quarry area, horizontal-dipole mode, 20-meter spacing.

activities of a Connecticut Department of Transportation asphalt plant reportedly located at Gallup's Quarry in the 1950's and early 1960's during the construction of what is now Interstate 395 (Paul Marin, Department of Environmental Protection, written commun., 1982). The last structure associated with this plant was removed prior to the 1975 aerial photographs. It seems improbable that contamination generated at least 7 years before the collection and analyses of sediment samples in October 1981 would persist at the measured concentrations and then essentially dissipate within a month. If the same sampling and analytical protocols were followed in October and November of 1981 and the replicate samples were collected at the same locations, the noticeable decrease in concentrations of acetone and MEK may be indicative of a more recent discharge of contaminants. 

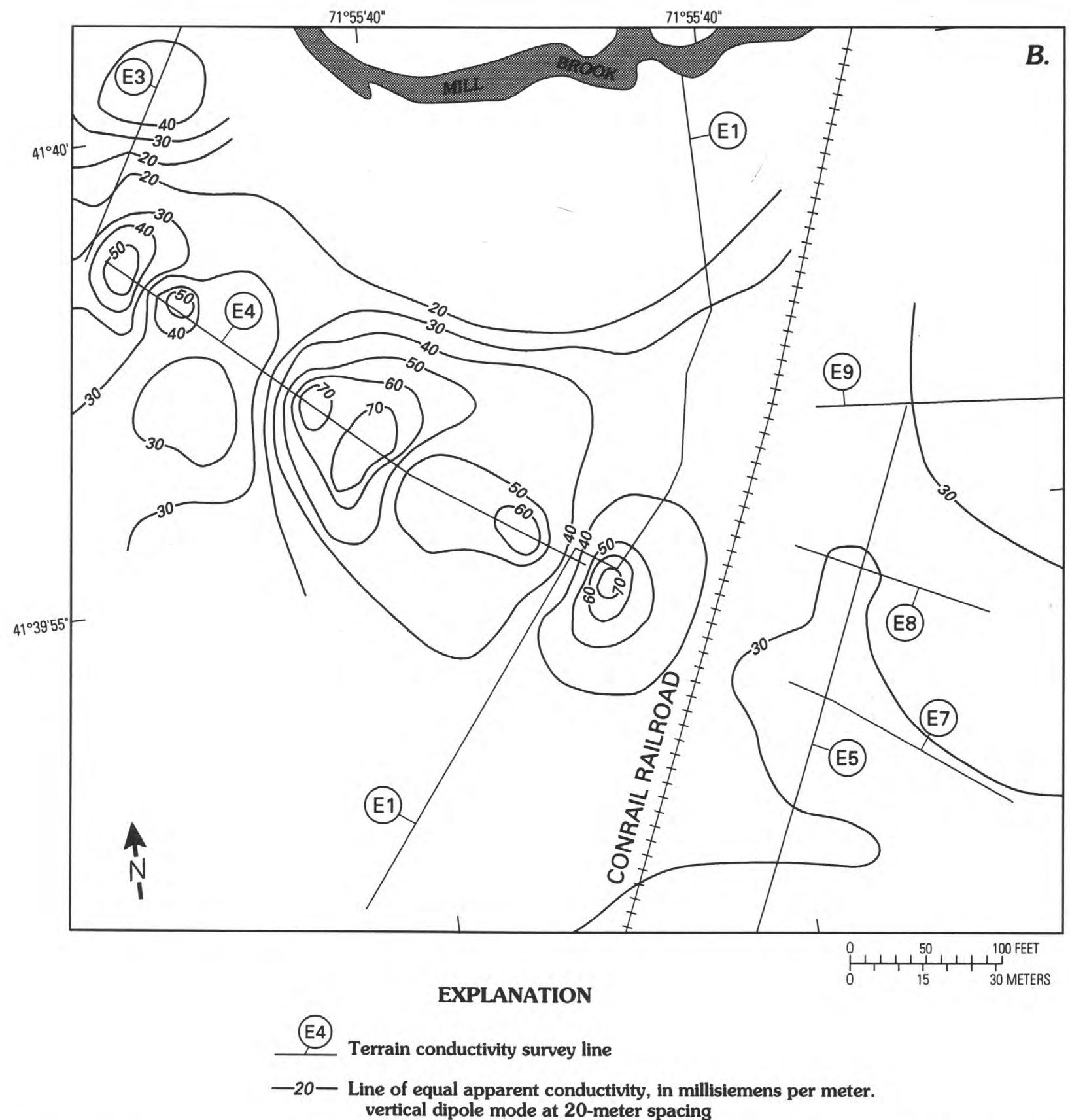

Figure 13B. Lines of equal apparent terrain conductivity in the Gallup's Quarry area, vertical-dipole mode, 20-meter spacing.

\section{DATA NEEDS FOR REMEDIAL INVESTIGATION AND FEASIBILITY STUDY}

Existing geohydrologic information for the Gallup's Quarry area, although relatively abundant, is insufficient for (1) assessing the movement and fate of contaminants since the cessation of waste disposal;
(2) evaluating the present residual contamination of ground water, surface water, bottom sediments in Mill Brook and Packer Pond, and glacial sediments near the three waste-disposal areas; and (3) estimating future movement and fate of contaminants. The latter two elements are needed to determine whether remediation is necessary, to develop alternative remediation techniques, and to implement and conduct a remedial 
program. Without the collection and analyses of new geohydrologic data, it also will be difficult to evaluate sources of contamination of Mill Brook and the sediments beneath Mill Brook and Packer Pond; the potential for movement of contaminants beneath and north of Mill Brook in response to ground-water withdrawals; the problem, if any, that this movement would pose to the quality of public water supplies; and the probability of large-scale transport of contaminants out of Mill Brook Basin through a regional ground-water flow system in the fractured bedrock or through a bedrock fault believed to transect Gallup's Quarry. The geohydrologic data that will provide the necessary information include subsurface geologic mapping; measurements that define the distribution of hydraulic head in, and hydraulic properties of, glacial sediments and bedrock; and analyses of ground water, surface water, and sediments.

In the following discussion, an approach to further study of Gallup's Quarry, including a general plan of data collection, is presented. The data collection is seen as a phased iterative process in which the conceptual model of the geohydrology is periodically refined as more data are collected and analyzed. This process will likely lead to modification in subsequent data collection as the understanding of geohydrologic conditions and processes improves. It should also be emphasized that the following discussion applies only to Gallup's Quarry, and the approach and data collection at other sites is unique because of local geohydrologic conditions, the history of waste disposal, and what is already known about site conditions.

\section{Subsurface Geologic Mapping}

A first step in acquiring the knowledge needed to develop remedial programs is to map the subsurface geology north and west of Gallup's Quarry in detail in order to (1) define the thickness and texture of glacial sediments in areas that are downgradient of the wells installed by Fuss and O'Neill in 1978, (2) determine the extent to which buried coarse-grained stratified drift is continuous across the Mill Brook Valley north and northwest of Gallup's Quarry (particularly between Gallup's Quarry and the Gallup Water Service Company well field north of Mill Brook), and (3) define the distribution and orientation of subsurface fractures in the bedrock, including confirmation of a major bedrock fault near the former buried seepage bed. This subsurface mapping can be most efficiently accomplished through a combination of surface-geophysical methods and test drilling. The GPR surveys conducted during this study generally provided good definition of the bedrock surface and the internal stratigraphy of the stratified drift at Gallup's Quarry and should provide similar information in adjacent areas. Alternative methods, such as seismic reflection, could be considered if the GPR is not feasible or does not produce good subsurface images. The test drilling could begin with a pilot program wherein subsurface data would be continually reevaluated to determine additional needs for siting drill holes.

Other surface-geophysical methods that could be useful in defining the boundaries and internal features of the unconsolidated subsurface geologic units include seismic refraction and reflection, electrical resistivity, and electromagnetics. Continuous seismic-reflection surveys conducted on water bodies and on land have provided good definition of subsurface geology in similar glacial terrains (Haeni, 1988, p. 63-82). It may not be possible, however, to conduct a reflection survey on Mill Brook and Fry Brook, even at times of high flow, because of the shallowness of the water. Geologic interpretations made from geophysical records will be enhanced by use of the regional geologic models briefly described in this report but will also require a limited number of strategically located test holes.

Surface-geophysical methods and the combination of drilling and borehole-geophysical methods can be used to evaluate bedrock-fracture distribution and orientation. Several surface-geophysical methods have been used with variable degrees of success in detecting subsurface bedrock fractures and estimating their orientation. These methods include GPR, inductive terrain conductivity, direct-current resistivity, and seismic refraction. Lieblich and others (1992a and $1992 \mathrm{~b}$ ) have described the integrated use of these methods to detect bedrock fractures at two sites in New Hampshire that are geologically similar to Gallup's Quarry. Borehole-geophysical methods that could be applicable to fracture characterization at this site include acoustic televiewer, acoustic velocity, television, temperature, fluid resistivity, single-point resistance, flowmeter, radar, caliper, and dipmeter. Confirmation that a major WNW-trending fault is located near the former seepage bed at Gallup's Quarry can be made by drilling test holes that are designed to intersect the fault plane. The drilling technique could allow collection of continuous-core samples of the bedrock and subsequent borehole logging. 


\section{Head Distribution and Hydraulic Properties}

The next essential element for developing a remediation program is an extensive, quantitative assessment of the horizontal and vertical flow of ground water within and between the geohydrologic units. This assessment would require a network of observation wells in which water levels would adequately define the head distribution in each of the geohydrologic units and field or laboratory tests that would adequately define the hydraulic properties of these units. The observation-well network would consist of multilevel samplers or nests of piezometers that are open to short (1-ft-thick or less) zones within each geohydrologic unit and will extend to, and probably beyond, the inferred limits of the groundwater flow system in this area (beyond Mill Brook). The exact configuration of the network and the total number of observation points cannot be estimated at this time. The network would be developed sequentially, and its design would be modified as new geohydrologic information is collected and evaluated. However, one area where it is important to measure vertical head distribution and hydraulic properties in the initial phase of network development coincides with the reach of Mill Brook between the Conrail railroad bridge and Fry Brook. Mill Brook has been inferred to be the principal discharge area for contaminated ground water that originates at Gallup's Quarry. This inference, although conceptually reasonable, is based on sparse water-quality data without supporting hydraulic data. Vertical head distribution in glacial deposits and bedrock beneath Mill Brook and the stage of Mill Brook are important data for assessing rates of vertical ground-water flow and ground-water discharge. It may also be possible to use vertical temperature profiles beneath this stream to determine rates of vertical ground-water flow and effective vertical hydraulic conductivity of the underlying sediments. This technique and its application are described by Lapham (1989).

Fuss and O'Neill (1979, p. II-9) considered the ground water in the unconsolidated deposits and the underlying bedrack to be part of a single flow system that discharges to Mill Brook and to adjacent wetlands. An alternative view is that some ground water in the bedrock is moving through a larger and deeper regional bedrock flow system that discharges to the Quinebaug River. Fuss and O'Neill's interpretation of the flow-system boundaries could be substantiated by measuring the vertical heads within the bedrock and glacial deposits. This would require drilling wells into bedrock deep enough to isolate different vertical intervals and measure head within each interval. Borehole logs, such as flowmeter and temperature logs, can also provide useful information on groundwater flow within the bedrock.

Hydraulic properties of the geohydrologic units are difficult to determine accurately without affecting contaminant distribution. Conventional aquifer tests, for example, would require movement and withdrawal of water that is likely to be contaminated, resulting in an alteration of the head distribution and contaminant concentrations in the region of the test well. A singlewell response (slug) test, where no water is added or withdrawn from the well bore, is a feasible method for estimating the horizontal hydraulic conductivity of the units. Numerous tests of this type are required for heterogenous aquifers because the hydraulic conductivity in only a small region around the well screen is measured by this method. Laboratory analyses of undisturbed sediment samples provide a means to determine hydraulic conductivity, storativity (specific yield), and porosity. Large numbers of these analyses are also required for characterizing heterogenous materials, and for some materials, such as fractured till, laboratory and field-determined values may differ. A less accurate method for estimating the bulk hydraulic conductivity of stratified drift is to use locally developed relations among grain-size distribution characteristics and hydraulic conductivity (Wilson and others, 1968).

The multilevel samplers or multiple nested wells used to determine head and hydraulic properties can be components of the sampling network to evaluate ground-water quality. Consequently, the well diameter should be sufficient to permit entry of waterquality sampling devises (and possibly boreholelogging tools), and the wells should be constructed of materials that will not affect results of water-quality analyses.

\section{Water-Quality and Residual Contaminants in Geohydrologic Units}

More than any other factor, the extent and degree of contamination of ground water, surface water, sediments, and perhaps bedrock will define the nature and required scope of remedial programs in the Gallup's Quarry area. Available water-quality monitoring data indicate that ground-water contamination has 
been detected near the original disposal area as recently as December 1986 (Kenneth Jones, NUS Corp., written commun., 1987). No data are available beyond the limits of the wells installed by Fuss and O'Neill in 1978, which are shown on plate 1, except for analyses of samples from domestic wells located along Route 12 to the east and Tarbox Road to the south. The contamination of Mill Brook by the discharge of contaminated ground water originating at Gallup's Quarry was reported as early as 1978 by Fuss and O'Neill (1979). Similar conclusions were made as late as November 1985 by the DEP staff conducting biological monitoring (Joseph Nestico, Department of Environmental Protection, written commun., 1986). Relations between the current water quality of Mill Brook and Gallup's Quarry would be inconclusive without additional data, including information on other potential sources of surface-water contamination.

The detection and assessment of ground-water contamination might be largely accomplished through analyses of geophysical data and the collection and analyses of water samples. It should be noted that the ground-water contamination at this site may be difficult to characterize in detail because of the information about the diverse contaminant sources and the heterogeneity of the geohydrologic units is incomplete. Numerical flow models that incorporate particle tracking could be a useful tool for synthesizing available information and refining hypotheses about ground-water flow paths and contaminant transport. Surface-geophysical methods, such as electromagnetic and electrical-resistivity surveys, have been applied with variable degrees of success in detecting contaminated ground water. A more comprehensive electromagnetic or an electrical-resistivity survey could be conducted downgradient of the disposal sites to detect possible anomalies in conductivity or resistivity that may be related to ground-water contamination. Similarly, several boreholegeophysical methods (resistivity, spontaneous potential, and induction) can provide qualitative and quantitative data on water quality. Some of these methods may require an uncased hole or casing constructed of specific material. It would be very difficult to construct an uncased hole without introducing drilling fluids into the subsurface that could affect analyses of ground-water quality.

Reconnaissance sampling and analyses of ground water in the stratified drift would indicate the types of constituents likely to be found in subsequent samples; this would also aid in the selection of additional sampling locations. Several devices are available to collect water samples from different zones in unconsolidated sediments, either during drilling or as an independent procedure. The water samples can be immediately analyzed by use of portable instruments, such as field gas chromatographs (GC's). The use of multilevel samplers and (or) multiple nested wells for measuring head and collecting ground-water samples has already been discussed. The data collected by analyzing samples from these wells will likely be the principal source of information on ground-water quality, particularly in the till and fractured bedrock units.

An assessment of water quality in Mill Brook will require collection and analyses of samples from at least two sites-one upstream from Gallup's Quarry to define background quality and a second within the reach that would be most affected by the discharge of ground water derived from waste-disposal areas at Gallup's Quarry. Sampling and analysis are most important during low-flow periods when streamflow is largely derived from ground-water discharge. Collection and analyses of samples collected at higher flows are also necessary to characterize surface-water quality. Each time surface-water samples are collected, the discharge of Mill Brook should be measured or estimated from stage measurements if there is an established stage-discharge relation in order to estimate loads. The concurrent sampling of water from Mill Brook and ground water from wells adjacent to or beneath Mill Brook would be very useful in assessing the effect of any ground-water-borne contaminants on the quality of water in Mill Brook. Finally, biological monitoring may provide a long-term indicator and integrator of water quality in Mill Brook. This could be done at the same sites used in the earlier DEP monitoring program.

Samples of sediment from the streambed of Mill Brook and possibly the bottom of Packer Pond need to be collected and analyzed for selected organic and inorganic constituents. The focus would be on constituents likely to have been derived from the waste disposal at Gallup's Quarry and for which no other potential upstream sources are known. The collection and analyses of sediment cores from Packer Pond may give a qualitative measure of changes in concentrations over time as well as a quantitative measure of the total volumes of sediment that contain various concentrations of contaminants. 
The presence of contaminants that are not dissolved in ground water may be detected by the analyses of samples of pore fluid, glacial sediments, and the outer surfaces of fractures in the bedrock. There is also the possibility that the contaminants could be detected by surface-geophysical methods, such as electromagnetic and resistivity surveys.

Direct methods involving the collection and analyses of sediment or rock samples generally are the most reliable ways to determine whether residual contaminants are present in pore fluids or have been precipitated and (or) sorbed on mineral grains or fracture surfaces. The most comprehensive sampling would entail continuous coring of the geohydrologic units, starting at land surface and ending in the bedrock. Discrete intervals from each core could be selected for analyses, based on the results of borehole logging, field gas-chromatographic analysis, and grain size. Continuous coring and comprehensive sampling and analyses of the cored materials are most important beneath and adjacent to the three former wastedisposal areas. The discovery of residual contamination in stratified drift near the secondary barrel disposal pit was described in the section "Glacial Sediments." Other areas that may warrant continuous coring and analyses, at least for reconnaissance, are the areas northwest of the three waste-disposal locations where the electromagnetic survey measured high values of terrain conductivity. (See fig. 13.)

Residual contamination by DNAPL's near all three former waste-disposal areas could differ in subsurface distribution and behavior from residual contamination by other constituents. Concentrations of these compounds in some ground-water samples were in the range of tens of thousands of micrograms per liter, indicating that large volumes of DNAPL's were disposed of. These large quantities could sink through the unsaturated and saturated zones leaving residual amounts trapped in small pores. The DNAPL's could also accumulate on surfaces that have low permeability or are impermeable, including any closed depressions on unfractured buried bedrock surfaces.

\section{SUMMARY AND CONCLUSIONS}

Unregulated disposal of an unknown volume of chemical waste occurred at three known locations in the northem part of an inactive sand and gravel pit known as Gallup's Quarry, located in the town of Plainfield, Conn., at least from the summer of 1977 until January 1978. Contaminated sediments were removed in 1978, but no other remedial work has been done to date (1993). The USGS conducted a study of the Gallup's Quarry area in the summer and fall of 1992. Existing geohydrologic information was reviewed, and geologic mapping, geophysical surveys, streamflow gaging, and drilling were conducted. Monitoring wells and domestic wells were located by means of published reports and drillers' records.

Stratified-drift deposits overlie till and bedrock in most of Gallup's Quarry and the area to the north and west. These deposits consist of gravel, sand and gravel, sand, and very fine sand, silt and clay (finegrained deposits); textural changes occur vertically as well as laterally. Various types of deposits are mapped in detail on plate 2, which was prepared from existing well and test-hole logs, GPR data, and geologic interpretations based on regional knowledge of glacial-meltwater depositional systems in the area north and west of the site.

In the northern part of Gallup's Quarry, where waste disposal occurred, fine-grained deposits consisting of sand, silt, and clay are underlain by highly permeable gravel and sand. This stratigraphic relation continues northwest of the quarry at least to Mill Brook and Fry Brook and may be present, either continuously or discontinuously, over a broader area that extends to the Gallup Water Service Company well field about $0.75 \mathrm{mi}$ NNW of Gallup's Quarry.

The saturated coarse-grained stratified drift that extends to the north from Lillibridge Road through Gallup's Quarry and the Gallup Water Service Company well field, has been identified in earlier USGS studies as an aquifer capable of supplying large quantities of water. Present withdrawals from this aquifer by the Gallup Water Service Company range from 0.3 to $0.4 \mathrm{Mgal} / \mathrm{d}$, but the aquifer is estimated to be capable of yielding $2.3 \mathrm{Mgal} / \mathrm{d}$ (Randall and others, 1966).

Recharge to stratified drift and hydraulic properties of stratified drift have not been measured at Gallup's Quarry. Average annual recharge for the period 1978-91 is estimated to be 30 in. Estimates of hydraulic properties based on texture (grain size and sorting) cover broad ranges and are of limited use in site-specific studies. Analysis of aquifer-test data for a well at the Gallup Water Service Company indicates that the horizontal hydraulic conductivity of the coarse stratified drift (gravel and sand and gravel) may be several hundred feet per day. 
The bedrock surface is directly overlain in most places by subglacially deposited till. The till is composed of a compact mixture of stones in a sandy, silty matrix and ranges from a few feet to as much as $20 \mathrm{ft}$ in thickness at Gallup's Quarry. Hydraulic conductivity and other hydraulic properties of this till have not been determined to date. Most hydraulicconductivity measurements for till made elsewhere in eastern Connecticut are in a fairly broad range of 0.04 to $24 \mathrm{ft} / \mathrm{d}$.

The crystalline bedrock beneath Gallup's Quarry is dark, fine-grained, jointed and fractured blastomylonite and gneiss. The hydraulic properties of this bedrock have not been determined to date and cannot be estimated from regional data. A WNW-trending fault, which is believed to pass through the central part of Gallup's Quarry, may provide a preferential pathway for ground-water flow and contaminant transport. The bedrock is overlain by glacial sediments 0 to $90 \mathrm{ft}$ thick. The bedrock surface slopes from an altitude of $200 \mathrm{ft}$ above sea level, where it crops out in the eastcentral part of Gallup's Quarry, to less than $100 \mathrm{ft}$ north and west of this area. Annual combined recharge to till and bedrock is estimated to have averaged 9.6 in. during 1978-91.

Analysis by the USGS of selected water-level data collected in 1978 by Fuss and O'Neill (1979) supports previous conclusions about the direction of horizontal ground-water flow in the stratified drift, including the dominant NW direction toward Mill Brook. The pattern of flow in July 1978 was almost radial; flow directions ranged from east, through the north, and to the west. In December 1978, flow was restricted to the northwest and west. Water-table gradients were 0.01 to almost 0.02 . The horizontal flow of ground water in the other geohydrologic units in 1978 is not known. The 1978 water-level data also indicate that upward and downward vertical gradients exist at Gallup's Quarry and that the directions of flow are locally variable. These gradients may have been affected by the disposal of the liquid wastes.

The flow of Mill Brook was measured in July, August, and September 1992 to establish a low-flow rating, and selected flow characteristics of the stream were estimated by use of regionalization techniques. Specific conductance of Mill Brook increased slightly downstream from the Conrail railroad bridge, but the relation of this increase to discharge of contaminated ground water from Gallup's Quarry is presently unknown.
Stained sand, observed near the former secondary barrel disposal pit during USGS field mapping, was analyzed and is reportedly contaminated by copper and cyanide compounds. High values of terrain conductivity measured in the area northwest of Gallup's Quarry could be caused by the presence of conductive ground water, sorption or precipitation of metals on the glacial sediments, and (or) to geologic conditions, including variable depth to bedrock, a bedrock structural feature, or variable lithology.

The geohydrologic information available for the Gallup's Quarry area is not sufficient to develop a remedial program. Suggestions regarding the geohydrologic information needed to develop remedial programs and address concerns, such as migration of contaminants to the northern side of Mill Brook, are summarized below.

(1) Detailed subsurface geologic mapping is needed, particularly north and west of the known wastedisposal areas.

(2) The distribution of head within the geohydrologic units and the hydraulic properties of each unit need to be determined to assess the present directions and rates of ground-water flow.

(3) The present extent and magnitude of the contamination of ground water, surface water, stream-bottom sediments, and glacial sediments need to be detemined in detail.

\section{REFERENCES}

Beres, Milan, Jr., and Haeni, F.P., 1991, Application of ground-penetrating-radar methods in hydrogeologic studies: Ground Water, v. 29, no. 3, p. 375-386.

Boynton, G.R., and Smith, C.W., 1965, Aeromagnetic map of the Plainfield quadrangle, New London and Windham Counties, Connecticut: U.S. Geological Survey Geophysical Investigations Map GP-541, scale 1:24,000.

Cervione, M.A., Jr., Mazzaferro, D.L., and Melvin, R.L., 1972, Water resources inventory of Connecticut, part 6, upper Housatonic River Basin: Connecticut Water Resources Bulletin 21, 84 p.

Cervione, M.A., Jr., Melvin, R.L., and Cyr, K.A., 1982, A method for estimating the 7-day, 10-year low flow of streams in Connecticut: Connecticut Water Resources Bulletin 34, $17 \mathrm{p}$.

Dixon, H.R., 1965, Bedrock geologic map of the Plainfield quadrangle, Windham and New London Counties, Connecticut: U.S. Geological Survey Geologic Quadrangle Map GQ-481, scale 1:24,000. 
1968, Bedrock geology of the Plainfield-Danielson area, Connecticut: U.S. Geological Survey Open-File Report 1126, 308 p.

Federal Emergency Management Agency, 1991, Flood insurance study, Town of Plainfield, Windham County, Connecticut: Washington, D.C., Federal Emergency Management Agency, June 17, 1991, 12 p., 9 panels.

Ferris, J.G., Knowles, D.B., Brown, R.H., and Stallman, R.W., 1962, Theory of aquifer tests: U.S. Geological Survey Water-Supply Paper 1536-E, p. 69-174.

Force, E.R., and Stone, B.D., 1990, Heavy mineral dispersal and deposition in sandy deltas of glacial Lake Quinebaug: U.S. Geological Survey Bulletin 1874, $21 \mathrm{p}$.

Fuss and O'Neill Inc., 1979, Evaluation of a chemical waste disposal area, Tarbox Road site, Plainfield, Connecticut: Manchester, Connecticut, January 1979, 92 p., 5 appendices.

Haeni, F.P., 1988, Evaluation of the continuous seismicreflection method for determining the thickness and lithology of stratified drift in the glaciated northeast, in Randall, A.D., and Johnson, A.I., eds., Regional aquifer systems of the United States-the northeast glacial aquifers: American Water Resources Association Monograph Series 11, p. 63-82.

Heath, R.C., and Trainer, F.W., 1968, Introduction to ground-water hydrology: New York, John Wiley and Sons, Inc., $284 \mathrm{p}$.

Knott, J.F., and Olimpio, J.C., 1986, Estimation of recharge rates to the sand and gravel aquifer using environmental tritium, Nantucket Island, Massachusetts: U.S. Geological Survey Water-Supply Paper 2297, 26 p.

Koteff, Carl, and Pessl, Fred, Jr., 1981, Systematic ice retreat in New England: U.S. Geological Survey Professional Paper 1179, $20 \mathrm{p}$.

Lapham, W.W., 1989, Use of temperature profiles beneath streams to determine rates of vertical ground-water flow and vertical hydraulic conductivity: U.S. Geological Survey Water-Supply Paper 2337, 35 p.

Lieblich, D.A., Haeni, F.P., and Cromwell, R.E., 1992a, Integrated use of surface-geophysical methods to indicate subsurface fractures at Tibbetts Road, Barrington, New Hampshire: U.S. Geological Survey Water-Resources Investigations Report 92-4012, 33 p.

Lieblich, D.A., Haeni, F.P., and Lane, J.W., Jr., 1992b, Integrated use of surface-geophysical methods to indicate subsurface fractures at Milford, New Hampshire: U.S. Geological Survey Water-Resources Investigations Report 92-4056, 38 p.

Mazzaferro, D.L., Handman, E.H., and Thomas, M.P., 1979, Water resources inventory of Connecticut, part 8 , Quinnipiac River Basin: Connecticut Water Resources Bulletin 27, 88 p.
Melvin, R.L., 1974, Hydrogeology of southeastern Connecticut: Connecticut Department of Finance and Control, Office of State Planning and Finance, 6 pls., scale 1:24,000.

Melvin, R.L., and Bingham, J.W., 1991, Availability of water from stratified-drift aquifers in the Farmington River Valley, Simsbury, Connecticut: U.S. Geological Survey Water-Resources Investigation Report 89-4140, 77 p.

Melvin, R.L., deLima, V.A., and Stone, B.D., 1992a, Stratigraphy and hydraulic properties of tills in southern New England: U.S. Geological Survey Open-File Report 91-481, 53 p.

Melvin, R.L., Stone, B.D., Stone, J.R., and Trask, N.J., 1992b, Hydrogeology of thick till deposits in Connecticut: U.S. Geological Survey Open-File Report 92-43, 43 p.

Metcalf and Eddy, Inc., 1992, Draft data summary report, start initiative Gallup's Quarry, Plainfield, Connecticut: Boston, Mass., U.S. Environmental Protection Agency contract no. 68-W9-0036, 43 p., 4 appendices.

National Oceanic and Atmospheric Administration, 1979-92, Climatological data, annual summaries, New England 1978-91: Asheville, North Carolina, National Oceanic and Atmospheric Administration, v. 90-104, various pagination.

Paillet, F.L., 1985, Problems in fractured reservoir evaluation and possible routes to their solution: The $\mathrm{Log}$ Analyst, v. 27, no. 6, p. 26-41.

Pietras, T.W., 1981, Leaching of nutrients in two watersheds under different land uses in eastern Connecticut: Storrs, Connecticut, University of Connecticut, unpublished master's thesis, $302 \mathrm{p}$.

Randall, A.D., Francis, R.M., Frimpter, M.H., and Emery, J.M., 1988, Region 19, Northeastern Appalachians, in Back, William, Rosenshein, J.S., and Seaber, P.R., eds., Hydrogeology: Boulder, Colorado, Geological Society of America, The Geology of North America, v. O-2, p. 177-187.

Randall, A.D., Thomas, M.P., Thomas, C.E., Jr., and Baker, J.A., 1966, Water resources inventory of Connecticut, part 1, Quinebaug River Basin: Connecticut Water Resources Bulletin 8, 102 p.

Rodgers, John, compiler, 1985, Bedrock geological map of Connecticut: Connecticut Geological and Natural History Survey, Natural Resources Atlas Series Map, 2 sheets, scale 1:125,000.

Schwille, Friedrich, 1988, Dense chlorinated solvents in porous and fractured media: Chelsea, Michigan, Lewis Publishers, Inc., $146 \mathrm{p}$.

Stone, B.D., 1974, The Quaternary geology of the Plainfield and Jewett City quadrangles, central eastern Connecticut: Baltimore, Maryland, The Johns Hopkins University, unpublished $\mathrm{Ph}$.D. thesis, $217 \mathrm{p}$. 
Stone, B.D., and Randall, A.D., 1977, Surficial geology of the Plainfield quadrangle, Windham and New London Counties, Connecticut: U.S. Geological Survey Geologic Quadrangle Map GQ-1422, scale 1:24,000.

Stone, J.R., Schafer, J.P., London, E.H., and Thompson, W.B., 1992, Surficial materials map of Connecticut: U.S. Geological Survey Special Map, 2 sheets, scale $1: 125,000$.

Theis, C.V., 1963, Estimating the transmissibility of a water-table aquifer from the specific capacity of a well, in Bentall, Ray, compiler, Methods of determining permeability, transmissibility and drawdown: U.S. Geological Survey Water-Supply Paper 1536-I, p. 332-336.

Thomas, C.E., Jr., Randall, A.D., and Thomas, M.P., 1966, Hydrogeologic data for the Quinebaug River Basin, Connecticut: Connecticut Water Resources Bulletin 9, $84 \mathrm{p}$.

Thomas, M.P., 1966, Effect of glacial geology on the time distribution of streamflow in eastern and southern Connecticut: U.S. Geological Survey Professional Paper 550-B, p. B209-B212.

1972, Gazetteer of natural drainage areas of streams and water bodies within the State of Connecticut: Connecticut Department of Environmental Protection Bulletin 1, $89 \mathrm{p}$.

Thomas, M.P., Bednar, G.A., Thomas, C.E., Jr., and Wilson, W.E., 1967, Water resources inventory of Connecticut, part 2, Shetucket River Basin: Connecticut Water Resources Bulletin 11, $96 \mathrm{p}$.

Torak, L.J., 1979, Determination of hydrologic parameters for glacial tills in Connecticut: Storrs, Conn., University of Connecticut, unpublished master's thesis, $161 \mathrm{p}$.
Trainer, F.W., 1987, Hydrogeology of the plutonic and metamorphic rocks, in Back, William, Rosenshein, J.S., and Seaber, P.R., eds., Hydrogeology: Boulder, Colorado, Geological Society of America, The Geology of North America, v. O-2, p. 367-380.

U.S. Environmental Protection Agency, 1986, Quality criteria for water, 1986: Washington D.C., U.S. Environmental Protection Agency Report EPA 440/5-86-001, unpaginated. 1990, Site analysis Gallup's Quarry, Plainfield, Connecticut: U.S. Environmental Protection Agency, Environmental Monitoring Systems Laboratory, $18 \mathrm{p}$. 1992, Final rule, National primary and secondary drinking water regulations-Synthetic organic chemicals and organic chemicals: U.S. Federal Register, v. 57 , no. 138 , July 17,1992 , p. 31, 776-31, 849.

Wentworth, C.K., 1922, A scale of grade and class terms for clastic sediments: Journal of Geology, v. 30 , p. 377-392.

Wilson, W.E., Ryder, R.B., and Thomas, C.E., Jr., 1968, Hydrogeology of southwestern Connecticut, trip B-3, in Orville, P.M., ed., New England Intercollegiate Geologic Conference, 60th annual meeting, New Haven, Conn., Oct. 25-27, 1968, Guidebook for fieldtrips in Connecticut: Connecticut Geological and Natural History Survey of Connecticut Guidebook 2, section B-3, 33 p.

Wintsch, R.P., and Sutter, J.F., 1986, A tectonic model for the Late Paleozoic of southeastern New England: Journal of Geology, v. 94, p. 459-472.

Zartman, R.E., and Naylor, R.S., 1984, Structural implications of some radiometric ages of igneous rocks in southeastern New England: Geological Society of America Bulletin, v. 95, p. 522-539. 
Alluvium. A general term for clay, silt, sand, gravel, or similar unconsolidated detrital material, deposited during comparatively recent geologic time by a stream or other body of running water, as a sorted or semisorted sediment in the bed of the stream or on its flood plain or delta.

Amphibolite. A crystalloblastic (metamorphic) rock consisting mainly of amphibole and plagioclase with little or no quartz.

Aquifer. A geologic formation, group of formations, or part of a formation that contains sufficient saturated permeable materials to yield significant quantities of water to wells and springs. In this report, the term principally refers to stratified-drift deposits known or inferred to be capable of yielding moderate to very large amounts of water to individual wells.

Blastomylonite. A mylonitic rock in which some recrystallization and (or) neomineralization has occurred.

Cataclasis. Rock deformation accomplished by fracture and rotation of mineral grains or aggregates without chemical reconstitution.

Cubic feet per second $\left(\mathrm{ft}^{3} / \mathrm{s}\right)$. A unit expressing rate of discharge. One cubic foot per second is equal to the discharge of a stream 1 foot wide and 1 foot deep flowing at an average velocity of 1 foot per second.

Deltaic foreset beds. Inclined layers of sandy material deposited upon or along an advancing and relatively steep frontal slope at the outer margin of a delta; in turn being covered or truncated by topset beds.

Deltaic topset beds. Nearly horizontal layers of gravelly sediments deposited on the top surface of an advancing delta. These beds truncate or disconformably overlie foreset beds in the delta.

Drawdown. The lowering of the water table or potentiometric surface caused by the withdrawal of water from an aquifer by pumping; equal to the difference between the static water level and the level during pumping.

Fault gouge. Soft, uncemented pulverized clayey or claylike material, commonly a mixture of minerals in finely divided form, found along some faults or between the walls of a fault, and filling or partly filling a fault zone.

Fissility. A general term for the property possessed by some rocks of splitting easily into thin layers along closely spaced, roughly planar, and approximately parallel surfaces, such as bedding planes in shale or cleavage planes in schist.

Flow duration. The percentage of time during which specified daily discharges have been equaled or exceeded within a given time period.
Flow duration of a stream. The percentage of time during which specified daily discharges were equaled or exceeded in a given period. The sequence of daily flows is not chronological.

Gaging station. A site on a stream, lake, or reservoir for systematic observations of gage height (water stage) or discharge.

Ground water. Water in the saturated zone.

Ground-water discharge. The discharge of water from the saturated zone by (1) natural processes such as flow or seepage into streams, evapotranspiration, and underflow, and (2) discharge through wells and other artificial structures.

Ground-water outflow. The sum of ground-water runoff and underflow; it includes all natural ground-water discharge from a drainage area exclusive of groundwater evapotranspiration.

Ground-water recharge. The amount of water that is added to the saturated zone.

Ground-water runoff. Ground water that has discharged into stream channels by seepage from saturated earth materials.

Gyttja. A dark, pulpy, freshwater mud characterized by abundant organic matter that is more or less determinable and deposited or precipitated in a marsh or in a lake whose waters contain high concentrations of nutrients and oxygen.

Hydraulic conductivity (K). A measure of the ability of a porous medium to transmit a fluid. A medium has a hydraulic conductivity of unit length per unit time if it will transmit in unit time a unit volume of water at the prevailing kinematic viscosity through a cross section of unit area, measured at right angles to the direction of flow, under a hydraulic gradient of unit change in head over unit length of flow path. It is usually given in units of feet per day ( $\mathrm{f} t / \mathrm{d})$.

Hydraulic gradient. The change in static head per unit of distance in a given direction. If not specified, the direction is generally understood to be that of the maximum rate of decrease in head.

Kettle holes. A steep-sided, usually basin- or bowlshaped hole or depression, commonly without surface drainage, in glacial-drift deposits, often containing a lake or swamp; formed by the melting of a large, detached block of stagnant ice (left behind by a retreating glacier) that had been wholly or partly buried in the glacial drift.

Late Wisconsinan. Pertaining to the last glacial stage of the Pleistocene Epoch in North America, lasting from approximately 25,000 years ago to 10,000 years ago. 
Lodgment till. A basal till commonly characterized by compact fissile structure and containing stones oriented with their long axes generally parallel to the direction of ice movement.

Morphosequence concept. Recognition that the retreating positions of the last ice sheet in New England can be traced by careful mapping of landforms, surface gradients, and textural distribution of meltwater deposits.

Mortar gneiss. Gneiss displaying cataclastic structure characterized by an aggregate of finely crushed grains of quartz and feldspar occupying the interstice between relics of the same minerals more resistant to granulation.

Mylonitization. Deformation of a rock by extreme microbrecciation, due to mechanical forces applied in a definite direction, without noteworthy chemical reconstitution of granulated minerals. Characteristically, the mylonites thus produced have a flinty, banded, or streaked appearance and undestroyed augen and lenses of the parent rock in a granulated matrix.

Natural recharge. Water that, under natural conditions, infiltrates to the saturated zone and supplies aquifers. In Connecticut, precipitation is the principal source of natural recharge.

Neomineralization. Chemical interchange within a rock whereby its mineral constituents are converted into new mineral species; a type of recrystallization.

Pleistocene. An epoch of the Quaternary period, lasting from 2 to 3 million years ago until the start of the Holocene Epoch about 10,000 years ago.

Porosity. The property of a rock or unconsolidated material of containing voids or open space; it may be expressed quantitatively as the ratio of the volume of open spaces to total volume of the rock or material.

Runoff. That part of the precipitation that appears in streams. It is the same as streamflow unaffected by artificial diversions, storage, or other works of man in or on the stream channels.

Saturated zone. The subsurface zone in which all interconnected spaces are filled with water. The water table is the upper limit of this zone. Water in the saturated zone is under pressure equal to or greater than atmospheric.

Specific capacity of a well. The rate of discharge of water divided by the corresponding drawdown of the water level in the well. It is usually given in units of gallons per minute per foot of drawdown $[(\mathrm{gal} / \mathrm{min}) / \mathrm{ft}]$.

Thrust fault. A fault with a dip of $45^{\circ}$ or less over much of its extent, on which the hanging wall appears to have moved upward relative to the footwall. Horizontal compression, rather than vertical displacement, is its characteristic feature.

Transmissivity. The rate at which water of the prevailing kinematic viscosity is transmitted through a unit width of aquifer under a unit hydraulic gradient. It is equal to the average hydraulic conductivity multiplied by the saturated thickness and is given as cubic foot per day per square foot times foot of aquifer thickness $\left[\left(\left(\mathrm{ft}^{3} / \mathrm{d}\right) / \mathrm{ft}^{2}\right) x \mathrm{ft}\right]$, which reduces to $\mathrm{ft}^{2} / \mathrm{d}$.

Unconfined aquifer (water-table aquifer). An aquifer in which the upper surface of the saturated zone-the water table-is at atmospheric pressure and is free to rise and fall.

Wentworth grade scale. A grain-size classification system, based on particle diameter, the divisions of which are as follows: boulders, $>256 \mathrm{~mm}$ (millimeters); cobbles, 256 to $64 \mathrm{~mm}$; pebbles, 64 to $4 \mathrm{~mm}$; very fine gravel, 4 to $2 \mathrm{~mm}$; very coarse sand, 2 to $1 \mathrm{~mm}$; coarse sand, 1 to $0.5 \mathrm{~mm}$; medium sand, 0.5 to $0.25 \mathrm{~mm}$; fine sand, 0.25 to $0.125 \mathrm{~mm}$; very fine sand, 0.125 to $0.063 \mathrm{~mm}$; silt, 0.063 to $0.004 \mathrm{~mm}$; clay, $<0.004 \mathrm{~mm}$. 